\title{
السمات المعمارية للمساجد بالمغربين الأدنى والأوسط فى العصر العثماني "دراسة مقارنة"
}

\section{Architectural features of the Ottoman mosques in the states of the Islamic West "A Comparative Archaeological Study}

\author{
عامر حسن أحمد عجلان \\ مدرس بقسم الآثار الإنسلامية- كلية الآثار - جامعة سوهاج.
}

Amer Hassan Ahmed Aglan

Lecturer in Islamic Archaeology department- Faculty of Archaeology-Sohag University ameraglan@arch.sohag.edu.eg

الملخص:

تمكنت الدولة العثمانية من فتح معظم الثمال الإفريقي وضمه إلى حوزتها، وتكونت ثلاث ولايات عثمانية فى الغرب

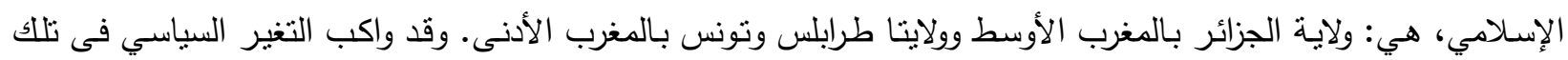

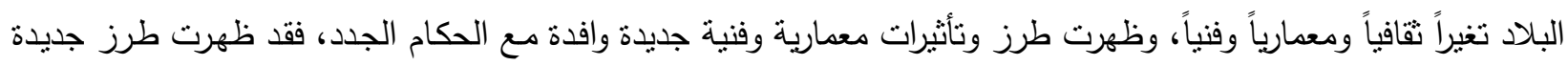

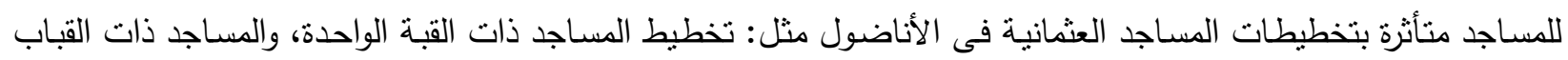
المتعددة، والمساجد ذات الوحدنين أو السلطانية. وفي الوقت ذاته وجدت مساجد عنمانية ظلت محتفظة بتخطيطها التقليدي

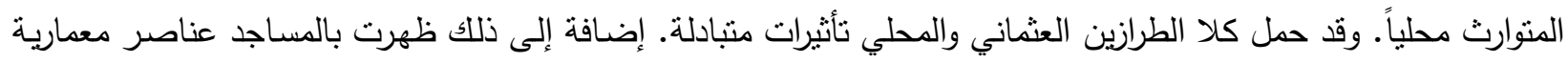

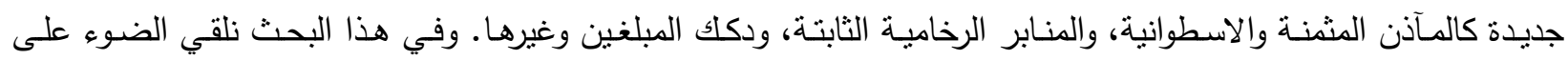

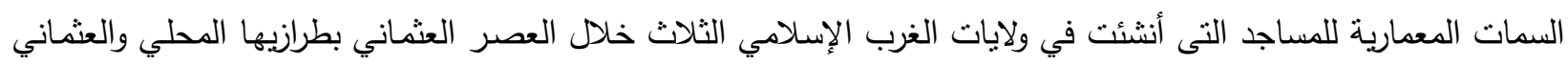
فى إطار مقارن بين تخطيطاتها وعناصرها المعمارية لإبراز أوجه التشابه والاختلاف بينها، وما يميز كل منها عن نظيرتها وعن غيرها من مساجد.

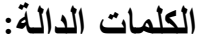

المساجد العثمانية؛ طرابلس؛ تونس؛ الجزائر.

\section{Abstracts:}

The Ottoman Empire was able to conquer most of North Africa and annex it to its possession, where three Ottoman states were formed in the Islamic West, which are: Algiers, Tripoli and Tunisia. The political change in those countries was accompanied by a cultural, architectural and artistic change, and new architectural and artistic styles and influences appeared with the new rulers, as new mosque models appeared influenced by the designs of Ottoman mosques in Anatolia, such as in planning mosques with one dome, mosques with multiple domes, and Imperial or two-units mosques. At the same time, it was found that Ottoman mosques kept their traditional, locally inherited plan. Both Ottoman and the local styles bore mutual influences. In addition, a new architectural elements appeared in mosques, such as octagonal and cylindrical minarets, marble pulpits, pews (recaller' benches) etc. In this paper, we shed light on the architectural features of mosques that were established in the three provinces of the Islamic West in the Ottoman era, with their local and Ottoman styles, in a comparative framework between their plans and architectural elements to highlight the 
similarities and differences between them, and what distinguishes each of them from its counterpart and from other mosques.

Key words: Ottoman Mosques, Tripoli, Tunis, Algeria.

المقدمة:

بعد سقوط الأندلس، قام الإسبان والبرتغاليون وبمساعدة فرسان القديس يوحنا بمهاجمة سواحل الغرب الإسـامي، وتمكنوا من احتلال كثير من مدنـه المهمة ونقاطه الاستراتيجية، إلى أن تدخل العثمانيون لإنقاذ هذه البلاد ووضـعوا حداً للتدخل الصليبي فيها، واستطاع العثمانيون تكوين ثلاث ولايـات لهم فى الثـمال الإفريقي وهي: ولاية الجزائر ، ولاية طرابس، وولاية تونس.

وقد مرت بلدان الثمال الإفريقي بعدة فترات، امتازت كل فترة منها بقدوم ممثلين لحضارات مختلفة، وهكذا تتوعت التأثيرات فى الناحية الفنية والمعمارية بتتوع منابعها، واتسم كل عصر بطابعه الذي يميزه عن بن العصـور السـابقة، إلا أنـه لـم يوجد أي انقطساع فى سلسـلة الحلقات التى تربط بين مختلف هذه الحقبـات التاريخيـة. وقد كان مجئ الأثراك العثمـنيين مصحوباً بحضدور عسكري وسياسي قوامـه الجند، وقد حاول الحكام الجدد بـث المذهب الحنفي عن طريـق العلم، فأسسـوا الجوامـع والمدارس لهذا الغرض، كمـا جددوا مساجد سـابقة ووقفوها على المذهب الحنفي. كما كان لتأثنرهم الفني والمعماري أهمية لا تقل عن تأثيرهم الثقافي والمذهبي، مما أعطى صبغة جديدة لفن البلاد ومعمارها، وهكذا أدى الوجود العثماني إلى ظهور خصـائص واتجاهات وطرز فنيـه جديدة'، إضـافة إلى استمرار الطرز والتأثنرات المحلية والأندلسية وكذلك الأوروبيـة. هذا المـزبج مـن التأثيرات الفنيـة التى ظهرت في عمـائر تلك البلدان والتى تعود إلى العصر العثماني كان نتيجة طبيعية لما كانت عليه أوضاع البلاد والتركيبة السكانية بها، فالنأثنرات التركية جاءت نتيجـة للفتح العثمـاني للبلاد ووفود ولاة أتراك وجيوش عثمانيـة، وكذلك حرص بعض القادة المحليين من الدايات والبايات على إظهار الولاء للاولة والحكومة المركزية بالأستانة والتقرب إلبها عن طربق إنشاء عمائر تحمل الطابع التركي العثمانيُّ والتأثيرات الفنية الأندلسية جاءت نتيجة هجرة آلاف المسلمين الأندلسيين واستقرارهم فى تونس بعد طردهم نهائياً مـن الأندلس، وكانت هذه الجاليـة الأندلسية الكبيرة تحتوي على هـئ مجموعة كبيرة من المعماريين والصناع وأصحاب الحرف وطوائف البنائين وغيرهم، واستغل الأتراك مواهب هؤلاء في أعمالهم المعمارية؛ ولذلك ظهرت التأثنرات الأندلسية بشكل جلي في كافة عمائر تلك الفترة. أما

بن مامي، محمد الباجي، "جوامع مدينة تونس فى العهد العثماني"، مجلة الاتحاد العام للآثاريين العرب، مج. ا، . . . rم، ' ريمون، أندريه، العواصد العربية عمارتها وعمرانها فى الفترة العثمانية، ترجمة: قاسم طوير ، دمثق: دار المجد، 919 ام، 
التأثثرات الأوروبية وخاصة الإيطالية فجاءت نتيجة عمل بعض الأسرى الإيطاليين ممن كانت لديهم الخبرة بالمعمار وفنون البناء، وكذلك استقرار بعض الإيطاليين الذين اعتتقوا الإسلام فى البلادّاّ.

وإذا كانت دراسة التنأثيرات الوافدة على العمائر مهمة؛، إلا أن هناك بعداً آخر لا يقل أهمية، يفسر

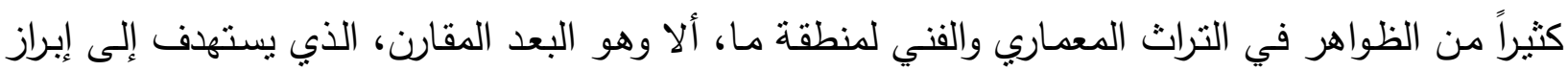

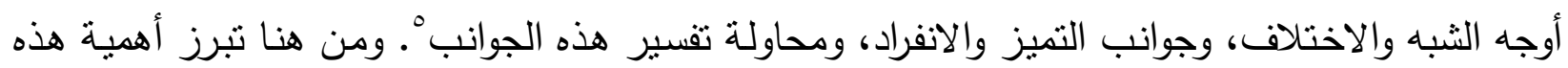

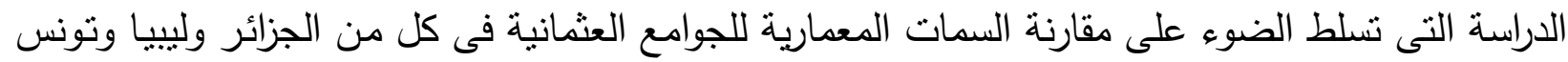
بصفتها بلدان الغرب الإسلامي التى خضعت للحكم العثماني، إضـافة لما بينها من قواسم مشتركة تاريخياً

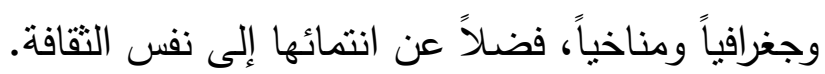

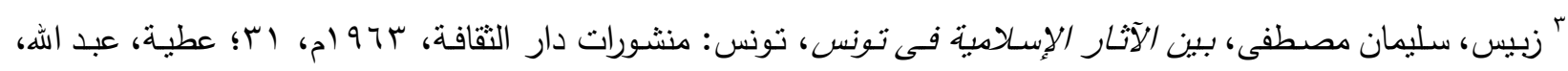

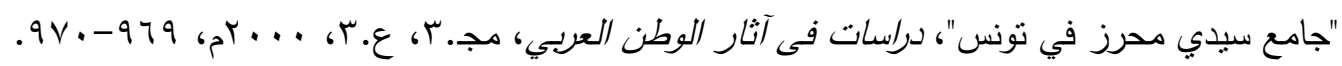

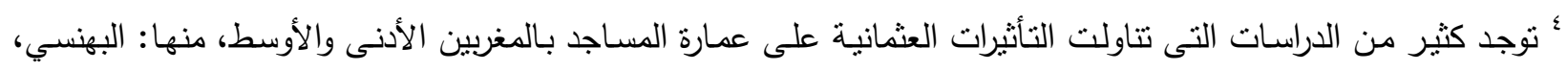

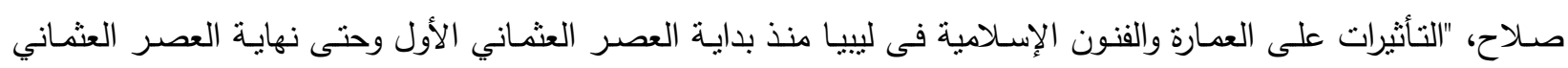

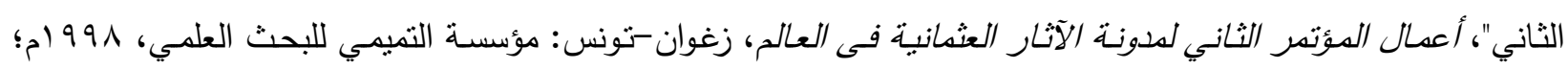

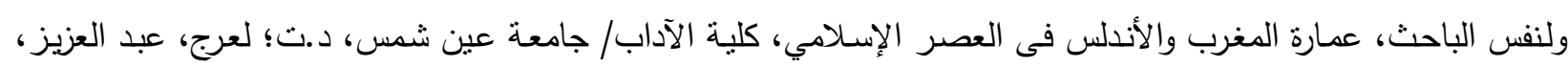

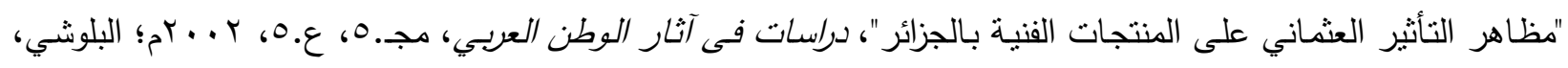
على مسعود، "نظرة على العمارة الدينية وتطورها فى ليبيا"، بحث ضمن كتاب: معالم الحضارة الإسلاعية في ليبيا ، القاهرة:

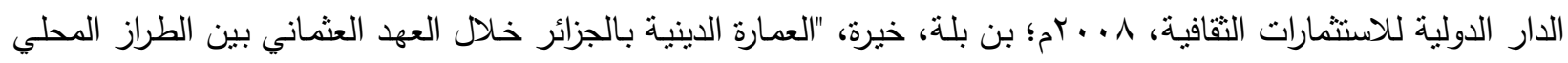

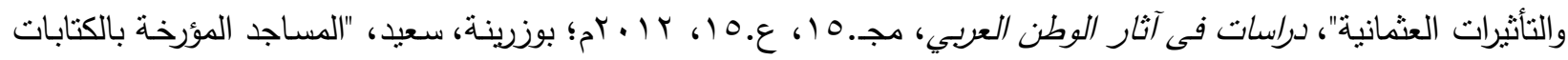

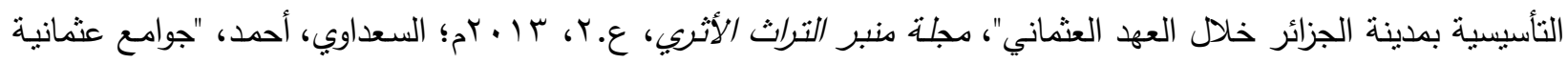

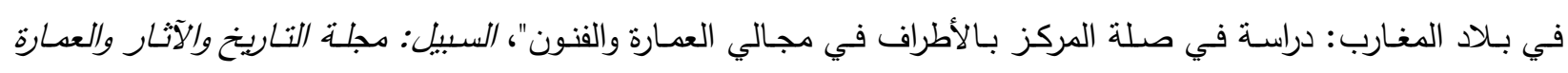

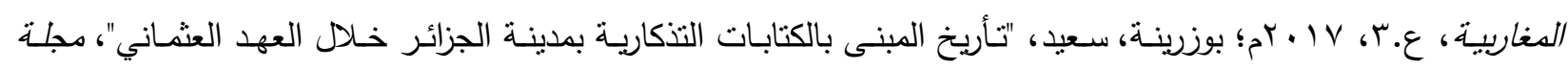

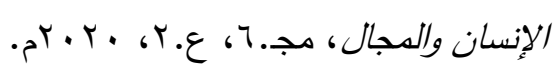

Ben Mami, M. B.: «La Mosquée M'Hammed Bey un exemple de la présence architecturale et artistique Ottomane dans la médina de Tunis ", AFRICA 12, Tunis: Institut national du patrimoine, 1998; BUHLFAIA, S.A .: « Historical background of Libyan mosque architecture », MasterThesis, Graduate School of Natural \& Applied Sciences, Middle east technical unive., 2006; AZLITNI, B .:«The Libyan architectural features between tradition and modernization ", International Journal for Housing Science 33, №. 3, 2009; Dhif, Sofien, "L'architecture religieuse de Tripoli à l'époque Kāramānlī (1711-1835). Genèse d'une mosquée "hétéroclie», Al-Sabîl : Revue d'Histoire, d'Archéologie et d'Architecture Maghrébines5, 2018; SAADAOUI. A, "Les marbres dans l'architecture religieuse de Tunis-XVIIe, XVIIIe et XIXe siècles", Al-Sabîl: Revue d'Histoire, d'Archéologie et d'Architecture Maghrébines 5, 2018; ALATRASH, ALATRASH, S, \& GURDALLI, H.: «Mosque Architecture in the Islamic Civilization in Libya», JOURNAL OF NEAR ARCHITECTURE1, №.2, April 2018.

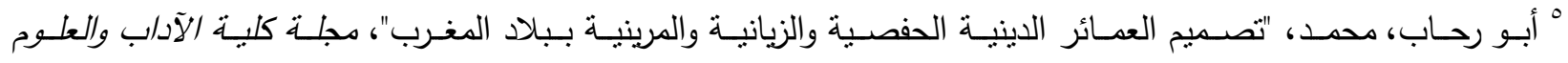

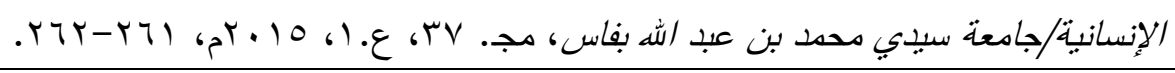


وقد خضعت الجوامع فى الجزائر وليييا وتونس فى العصر العثماني إلى كثير من الدراسات الآثارية

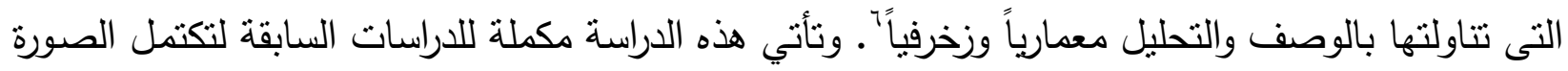

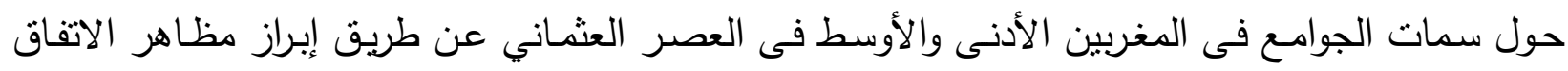
والاختلاف فى عمارة الجوامع فى الأقطار الثناثة.

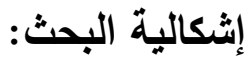

تتمثل إثكالية البحث فى المقارنـة بين المساجد ببلاد المغرب الأدنى والمغرب الأوسط خـلال العصر

$$
\text { هاف البحث: }
$$

يهدف البحث إلى إبراز مظاهر الاتفاق والاختلاف بين كل من المساجد في لييا وتونس والجزائر

خلال العصر العثماني؛ وذلك عن طريق المقارنة بين تخطيطاتها وعناصرها المعمارية.

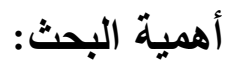

توضيح أوجه الثبه والاختلاف، وجوانب التميز والانفراد بين المساجد في الأقطار الثلاثة فى تلك الك

الفترة، وإيضاح السبب فى ذللك.

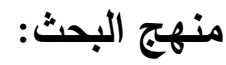

استخدم المنهج المقارن والدنهج التحليلي لرصد مظاهر الاتفاق والاختلاف بين المساجد في المغربين

الأدنى والأوسط فى الفترة قيد الدراسة ومحاولة تفسير هذه الجوانب.

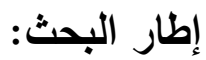

إطار مكاني: المغربين الأدنى والأوسط (ولاية طرابلس، ولاية تونس، ولاية الجزائر).

إطار زمني: يتمنل فى العصر العثماني فى تلك الأقطار .

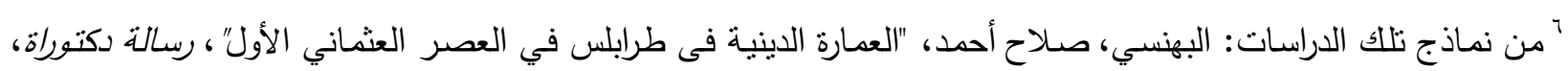

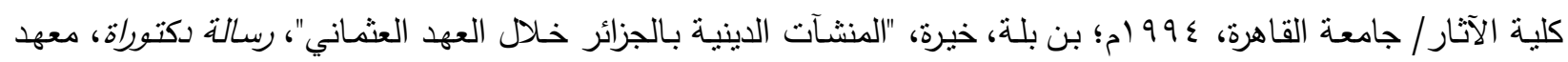

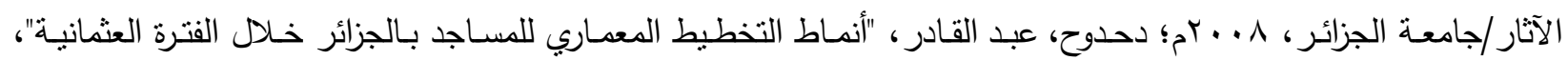

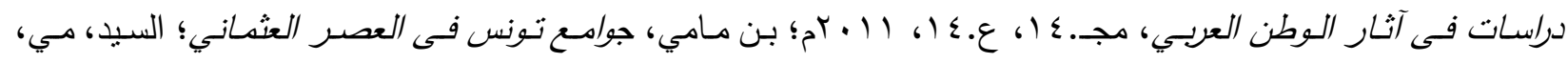

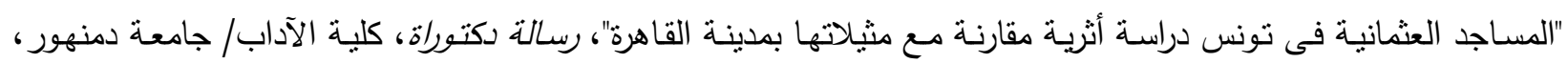

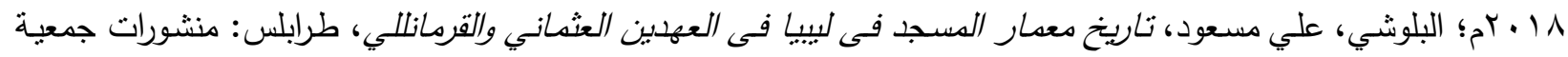




\section{1 أسمات التخطيط العام:}

من حيث التخطيط فقد تم تقسيم المساجد التى شُيُّت فى المغربين الأدنى والأوسط فى العصر العثـاني إلى طـرازين: الأول- مسـاجد بُنيت وفق الطراز المحلي، والثناني - مسـاجد بُنيت وفق الطراز العثماني •. واعتمد هذا التقسيم بثكل رئيس على وسائل التغطية فى تلاك المساجد سواء كانت أسقف مسطحة أو أقبية أو قباب والتى أثرت بصورة كبيرة - بجانب عوامل أخرى - على نوعية التخطيط. فالطراز المحلى فئى وسيلة تغطيته الرئيسة الأسقف المسطحة والأقبية، أما الطراز العثماني فئلت القباب القباب وسيلة تغطيته الرئيسة. ومن الجدير بالذكر أن عمارة المساجد ببلاد المغرب خلال العصر العثماني كانت عبارة عن مزيج بين الطراز المحلي والطراز العثماني الوافد من تركياء، حيث تعايش الطرازان العثماني والمحلي معاً وامتزجا

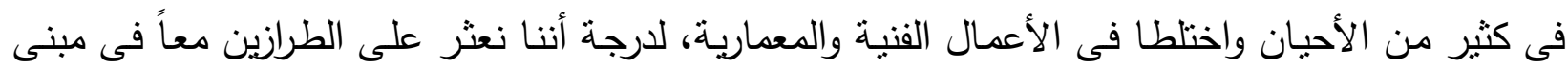
واحد". فلم يستعمل المعمار الطرازين معاً فقط، بل كان يجمع بين نمط تخطيطي محلي وعناصر معمارية

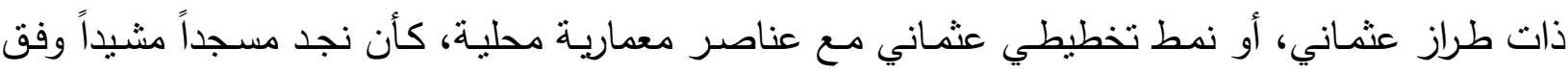

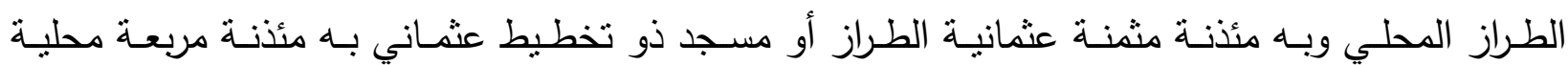
الطراز "'، ورغم ذلك ظل لكل طراز منهما مقوماته الرئيسة التى تميزه عن الآخر .

\section{1, ا ـ مساجد بُنيت وفق الطراز المحلي:}

وهي المساجد التى بنُيت وفق التخطيط النقليدي المتوارث محلياً، والذي ينكون من رواق للصـلاة أو

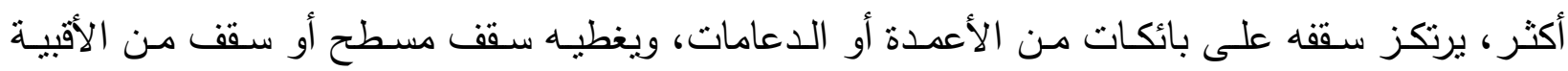

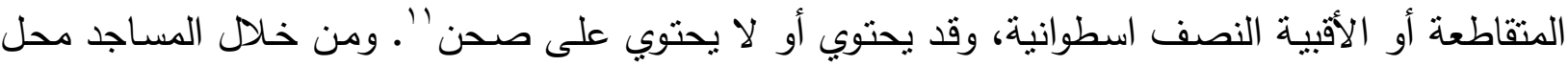

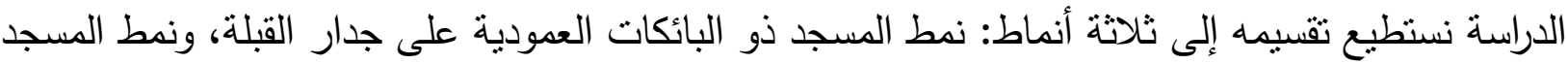

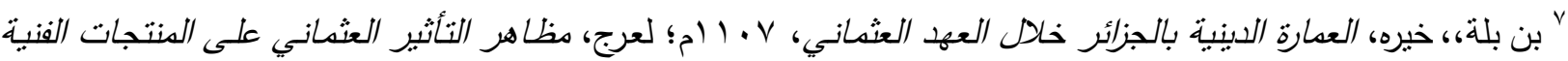

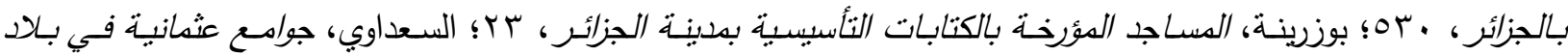

${ }^{8}$ MARÇAIS, G., L' Art en Algérie, Alger, Imprimerie Algérienne, 1906, 132.

$$
\text { 9 لعرج، مظاهر الثأثير العثماني على الكنتجات الفنية بالجزائر، بrv. }
$$

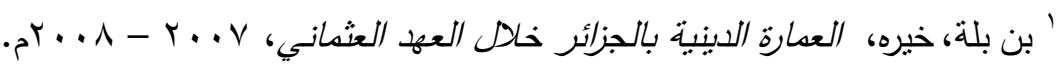

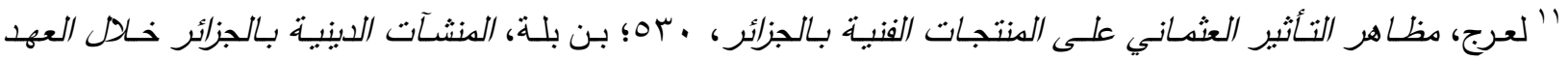

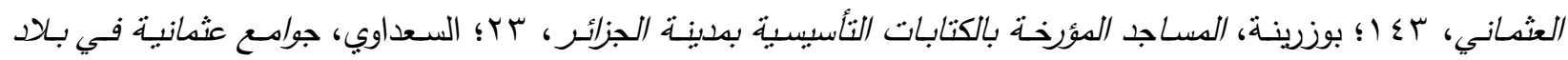




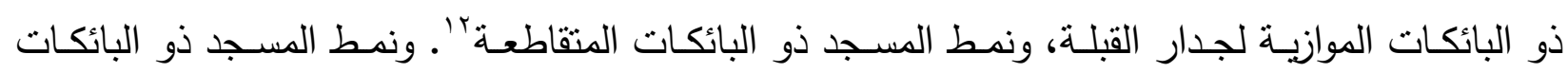
العموديـة على جدار القبلة ترجع أصسوله إلى المسـد الأقصى بالقدس الذي أعيد بنـاؤه فى صدر الدولة الأمويـة (0 (1)-هـ/

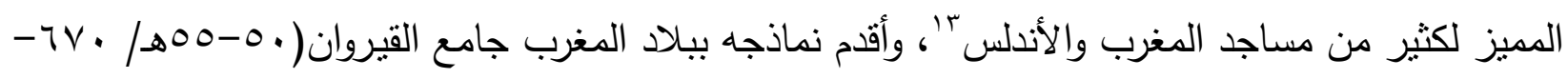
$\cdot\left(3_{T} \vee 0\right.$

ونمط المسجد ذو البائكات الموازيـة ترجع أصسوله إلى مسجد الرسول ومسـاجد الأمصـار مثل: مسجد

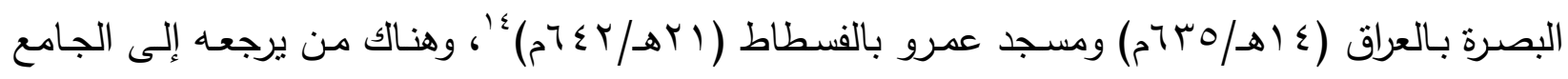
الأموي بدمشت (

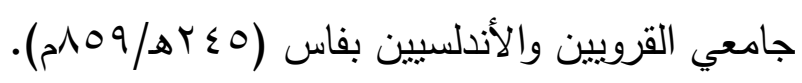

أما نمط البائكات المتقاطعة فكان أول ظهور لله فى العمارة الإسـلامية بشكل عام فى صهريج الرملة

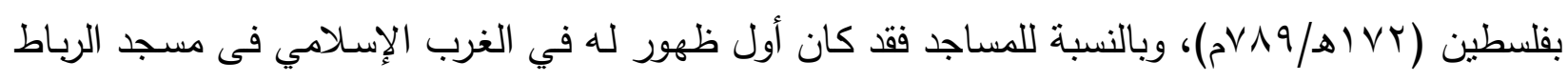

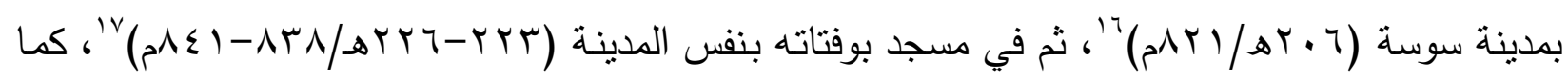

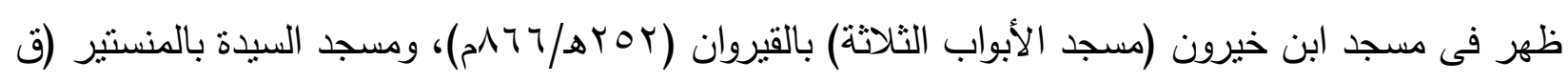
- 11

r' للاستزادة عن هذا الطراز وأنماطه، راجع: إبراهيم، فهيم فتحي، "أضواء جديدة على المساجد السلجوقية فى بلاد الأناضول"،

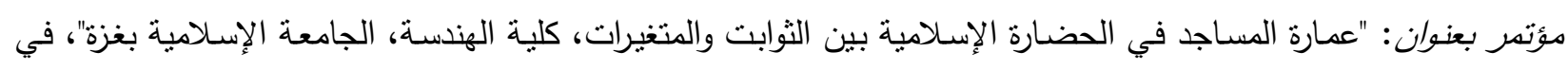

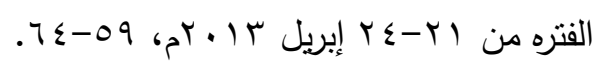

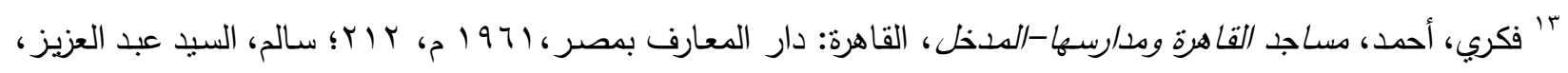

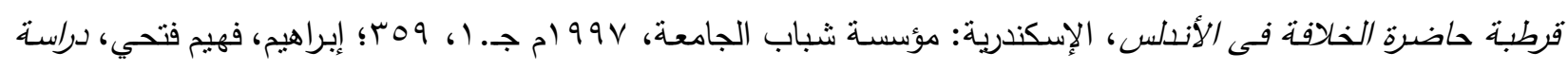

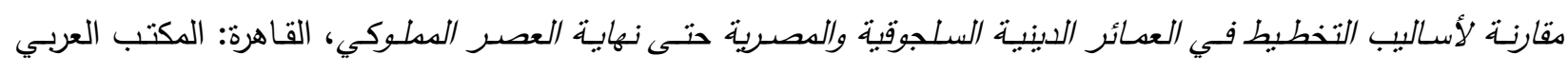

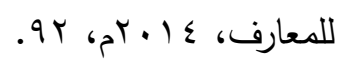

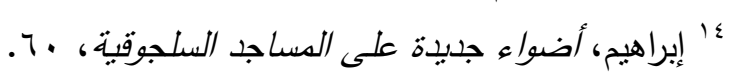

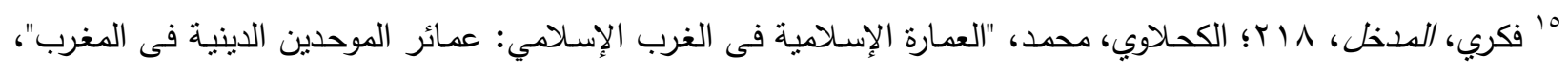

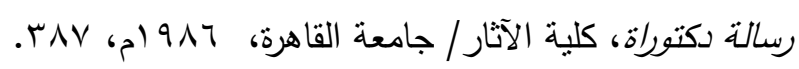

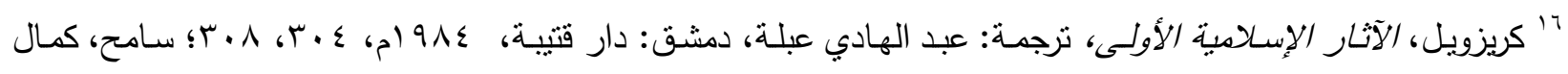

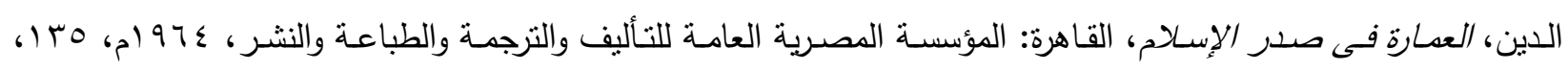

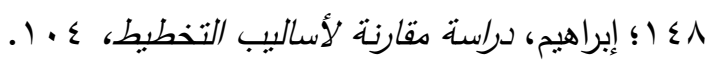

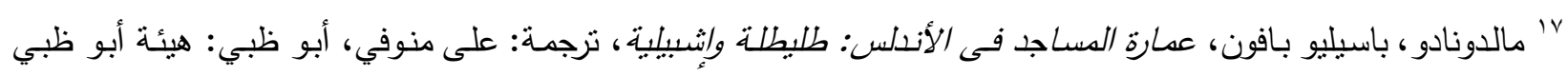

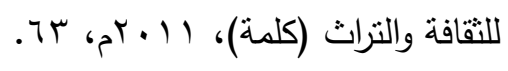
^' الحداد، محمد حمزة، "التخطيط غير التقليدي للمساجد فى الأندلس"، بحث منشور ضمن كتاب : بحوث ودراسات فى العمارة

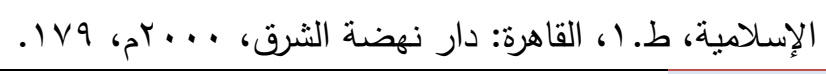


ويختلف نمط "البائكات المنقاطعة" عن نمط "القباب المتعددة"، حيث إن الأول وسيلة التغطية فيه عبارة عن أقبية منقاطعة (لوحة ()، وهو نمط محلي موجود فى عمارة المساجد منذ قبل العصر العثماني 19. نمط القباب المتعددة فوسيلة التغطية فيه هي القباب الضحلة (لوحة ب، ؟، ؟)، وهو نمط وافد مع الأتراك العثمانيين كما سيأتى ذكره.

\section{1, 1, 1, مساجد الطراز المحلي بولاية الجزائر:}

التخطيط العـام لتلك المسـاجد عبـارة عن بيت للصـلاة يثـل مسـاحة مستطيلة، يأخذ بعضهـا هيئة عرضية؛ أبي أن اتسـاع أو عرض بيت الصـلاة أكبر من عمقه. وهذه النوعية من التخطيطات هي أنسب المساقط لرواق الصلاة بالجوامع، خاصة أنه يتيح استطالة الصفوف الأولى للمصلين، وهو ما يتوافق مع ما ورد فى السنة النبوية المطهرة من أفضلية الصفوف الأولى عن التى تليها فى الثواب؛ لذا فهو أنسب من الأشكال الأخرى لأروقة الصلاة التى لا تعطى استطالة لصفوف المصلين كالدائرة والمثمن والمسدى ‘.

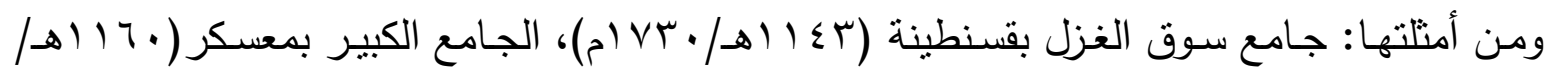

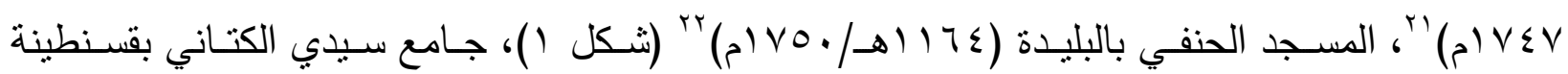

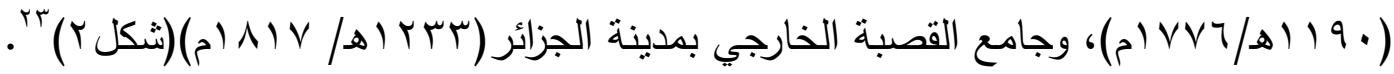
في حين أن هنالك جامعين فقط يأخذ بيت الصلاة فى كل منهما هيئة طولية؛ أي أن اتساع أو عرض

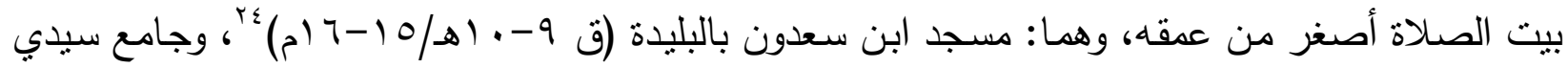

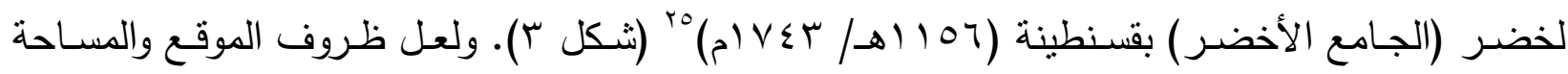
جعلتهما يأخذان هذا التخطبط.

19 وهو ما سيأتي ذكره تقصيلاً عند الحديث عن الأسقة.

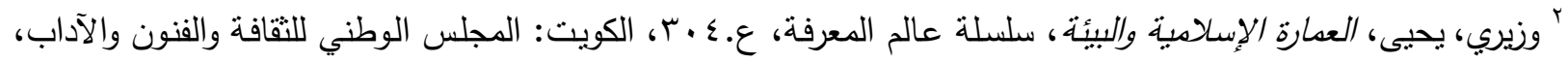

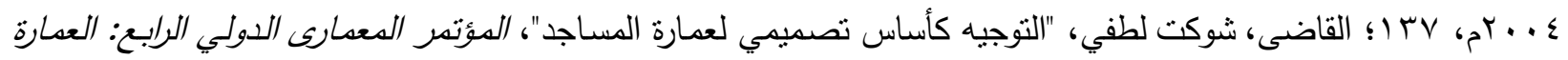

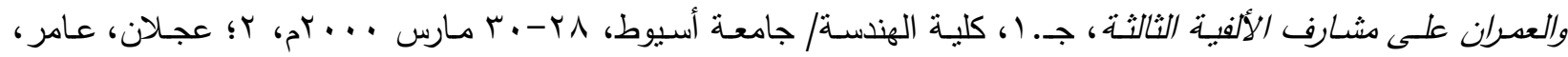

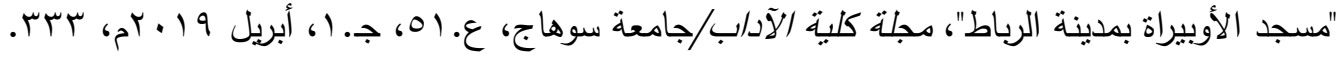

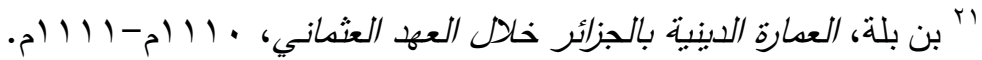

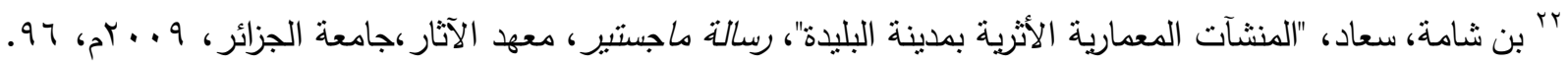

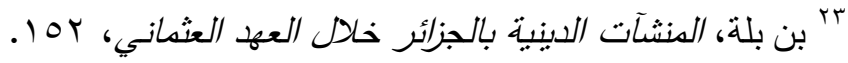

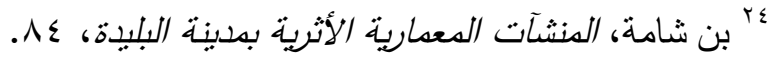

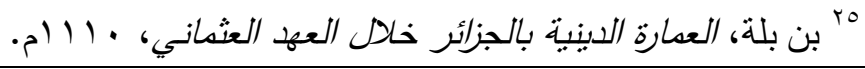


وقد اتبعت المساجد المحلية بالجزائر نمطين:

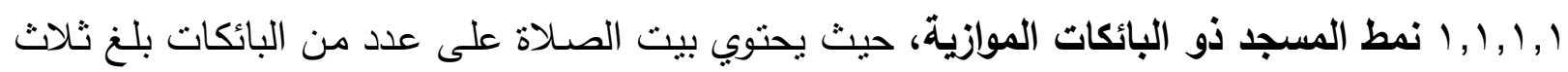

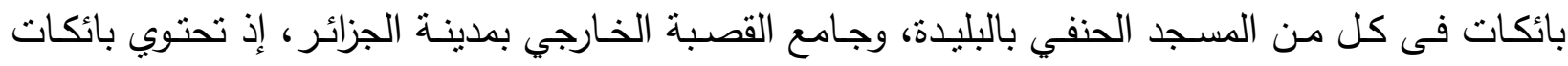

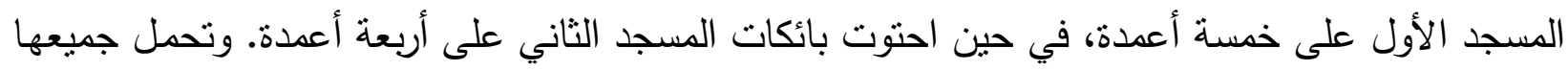

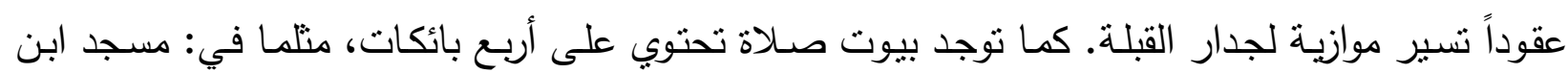

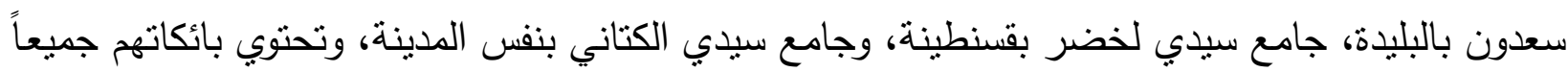

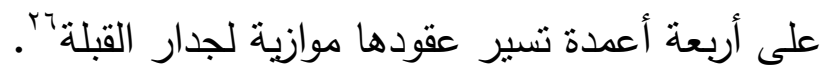

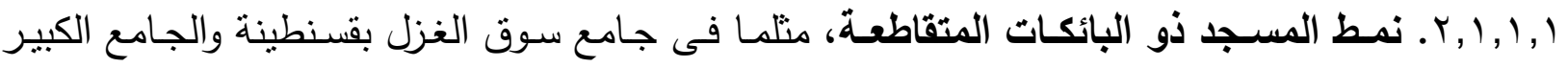
بمعسكر ، حيث يتكون كل منهما من ست بائكات عقودها عمودية على جدار القبلة، تنقاطع مع أربع بائكات

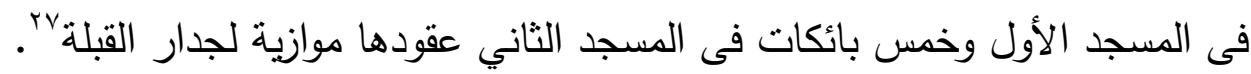
في حين لم نرصد بولايـة الجزائر مساجد تتبع النمط ذو البائكات العمودية؛ وذلك يرجع إلى طبيعة تخطيط بيوت الصلاة فى غالبية تلك المساجد والتى اتخذت هيئة عرضية انساعها أكبر من عمقها - كما

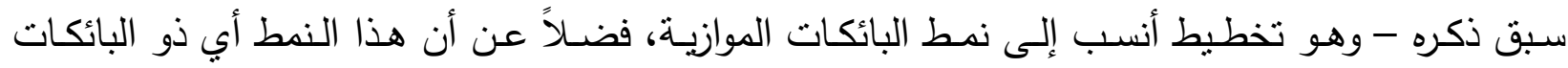

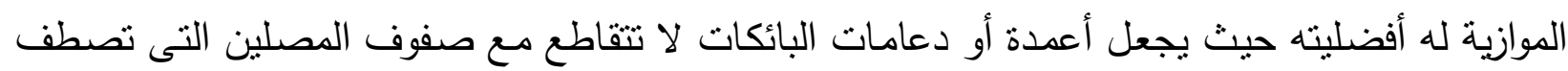

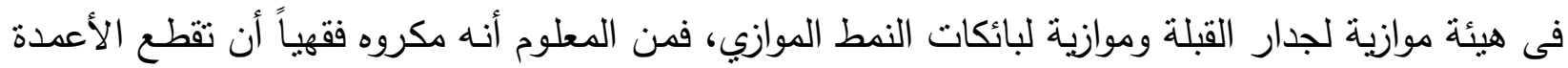
أو الدعامات صفوف المصلين.

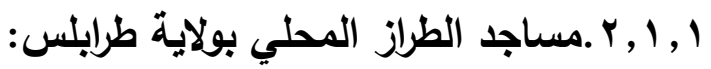
أما الجواهع محلية الطراز بولايـة طرابلس أو بالقطر الليبي فتخطيطها العام عبارة عن بيت للصـلاة

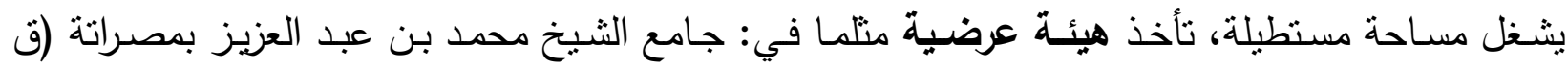

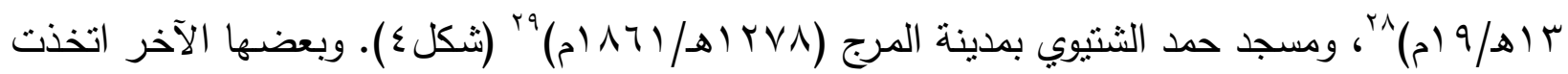

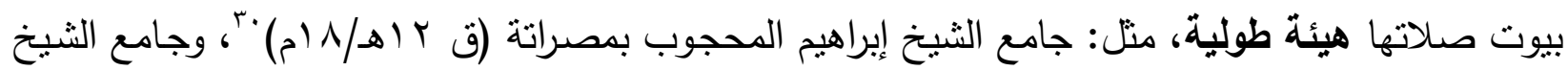

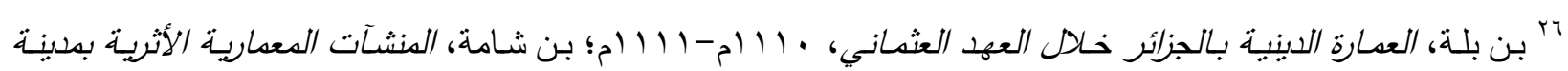

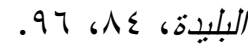

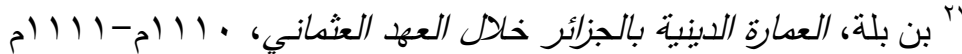

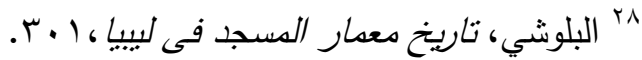

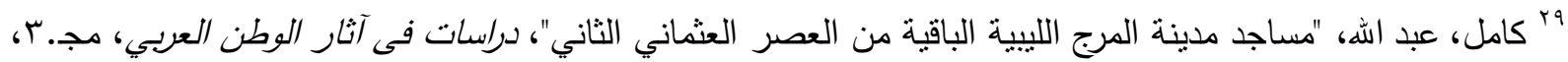
ع.r.

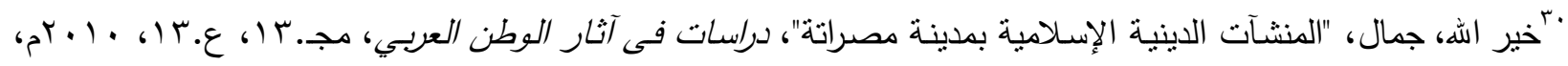




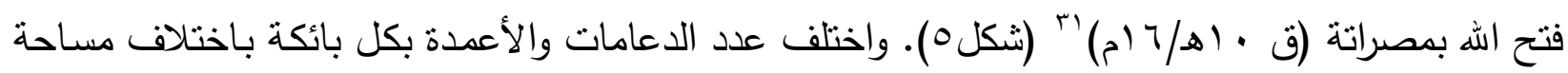
كل مسجد. وجاءت عقود البوائك إما موازية أو عمودية على جدار القبلة أو متقاطعة. أي أن مساجد الطراز المحلـي بليبيـا ظهـرت بهـا الثناتـة أنمـاط: ذو البائكـات العموديـة، وذو البائكـات الموازيـة، وذو البائكـات المنقاطعة.

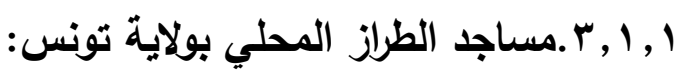

إن غالبيـة المسـاجد التى ترجـع للعصر العثــاني فى تونس بُنيـت على غرار الطراز المحلي. وجميع المساجد محلية الطراز تتكون من بيت للصسلاة يشـل مساحة مستطيلة اتساعها أكبر من عمقها. واحتوت

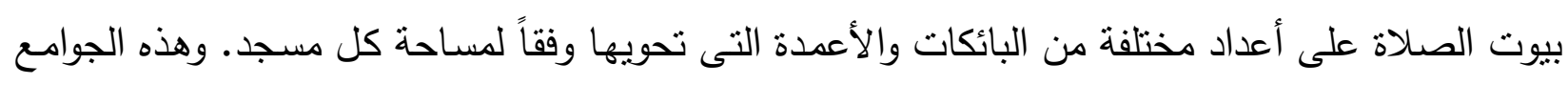

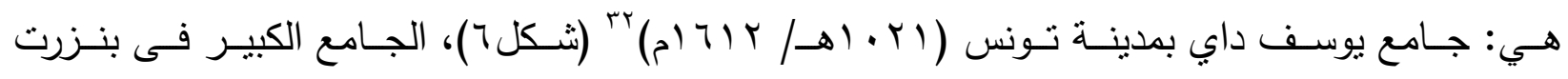

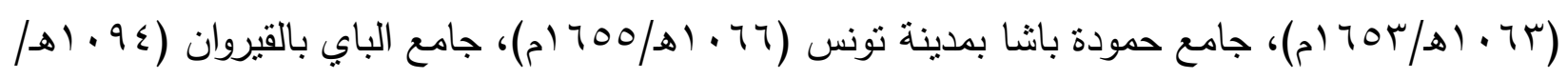

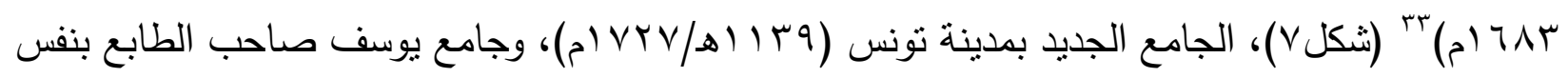

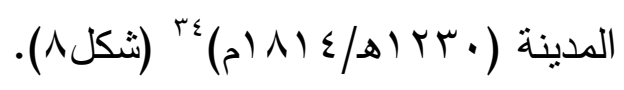

واختلف اتجاه العقود مـا بين عموديـة على جدار القبلـة أو موازيـة لـه أو متقاطعـة وفقاً لنوع التغطيـة المستخدم فى بيت الصلاة، أي أنه ظهرت بها الثلاثنة أنماط: ذو البائكات العدودية، وذو البائكات الموازيـة، وذو البائكات المتقاطعة. باستثناء جامع الباي في القيروان الذى يستتد سقهه على البائكات مباشـرة بدون عقود.

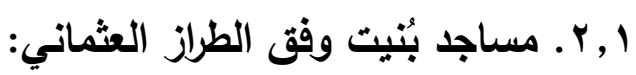

وهي المساجد التي حملت السمات العثمانية فى التخطيط والذي يتكون من بيت للصسلاة اعتمد فى تغطيته على القباب وأنصافها. وجميعها مشتقة من ثلاثة تخطيطات وافدة مع العثمانيين، هي: التخطيط ذو القبة الواحدة، والتخطيط ذو القباب المتعددة (لوحة ؟، ؟، ؟)، والتخطيط السلطاني أو ذو الوحدتين، والذي يتكون بيت الصلاة فيه من قبة مركزية وأنصاف قباب مع قباب صغيرة فى الأركان (لوحة ه، 7). وهذه النوعية من التخطيطات تعطي مساحة داخلية أكثر اتساعاً باستخدام أقل عدد من الأعمدة أو

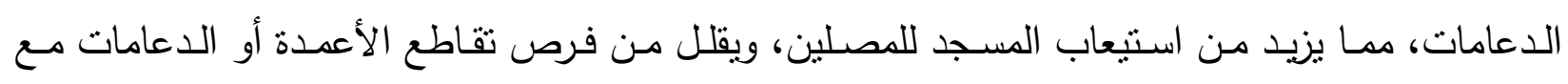
صفوف المصلين الأمر المكروه فقهياً. كما أن التغطية بالقباب تعطي فراغاً داخلياً أكبر لبيت الصلاة ومن ثم

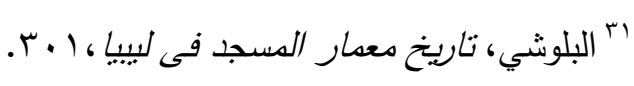

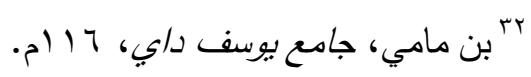

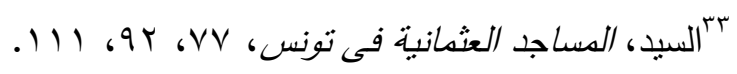

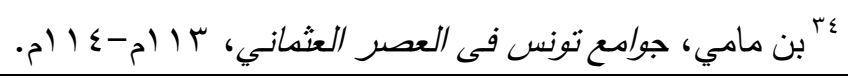


تهوية وإضـاءة أفضل دون الحاجة إلى فتح نوافذ كثيرة، وهو ما يتوافق مع طبيعة الطقس البارد فى بلدان الثمال الإقريقي خاصة فى فصل الثتاء.

وهـن الجدير بالذكر أن التخطيط ذي القبـة الواحـدة والتخطيط ذب القبـاب المتعددة لـم يكونــا مـن التخطيطات العثمانية الأصيلة، إنما وجدا منذ قبل العصر الإسلامي. فالتخطيط ذو القبة الواحدة ظهر في التى

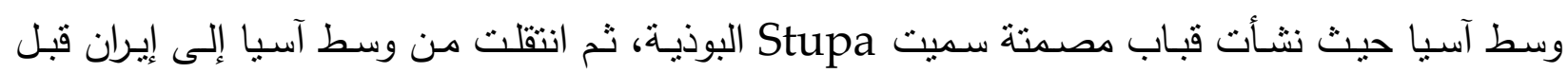

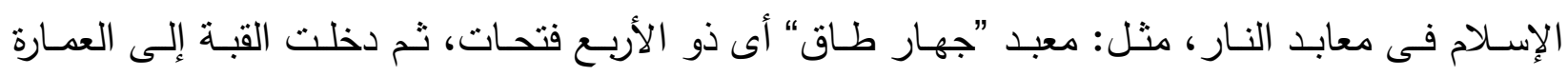

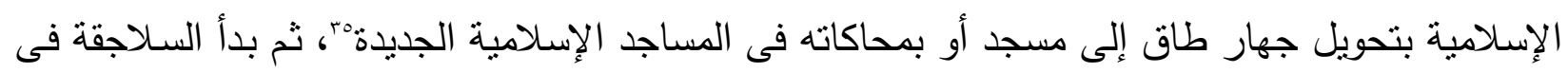

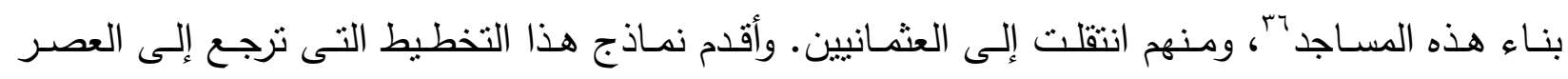

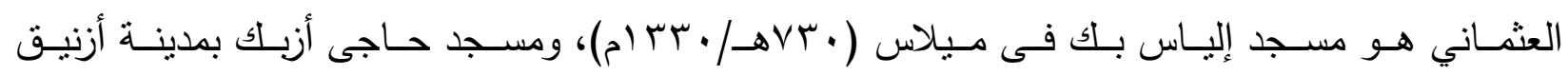

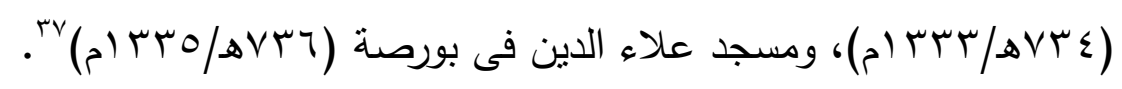

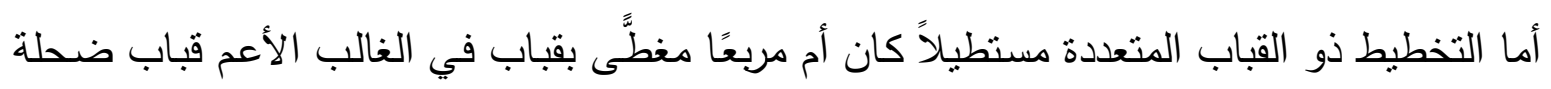

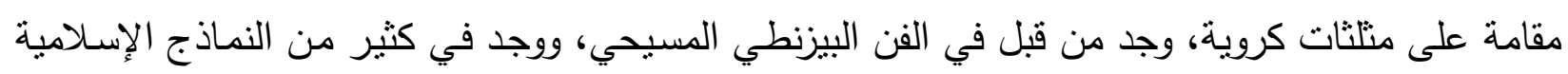

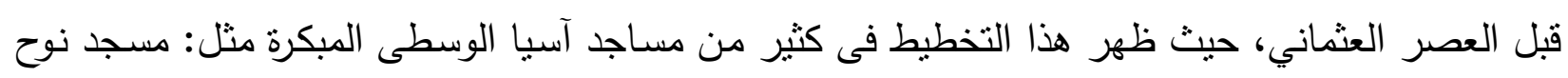

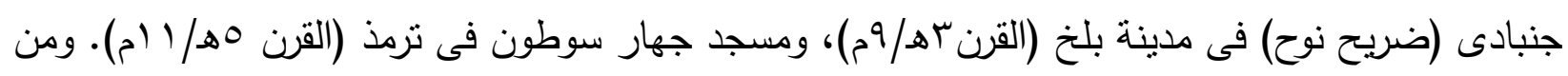
المساجد العثمانية التى اتبعت هذا الطراز مسجد أولو جامع (المسجد الكبير)، الذى أنثأه السلطان بايزيد

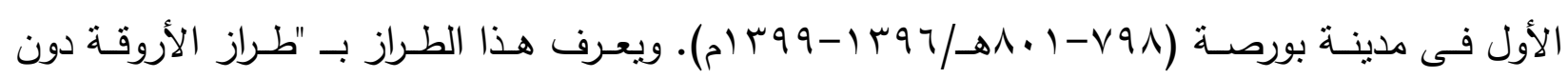

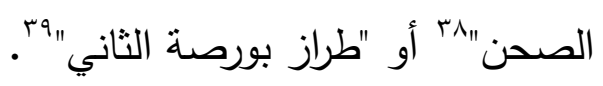

مبماضرة ألقاهـا أ.د. حمزة عبد العزيز بدر ، أستاذ العمارة العثانية، عن المساجد العثانية العبكرة، ألقيت بكلية الآثار

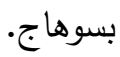

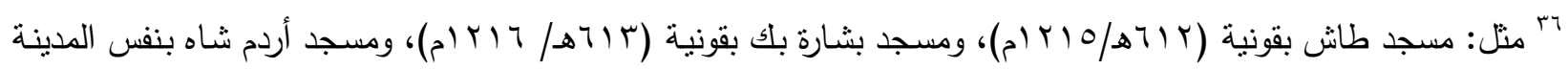

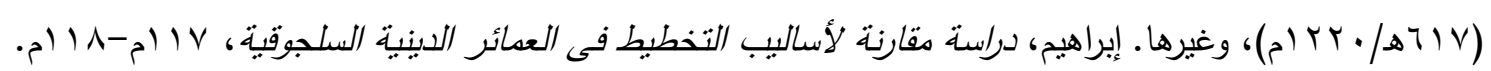

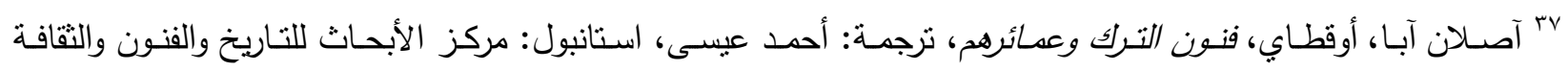

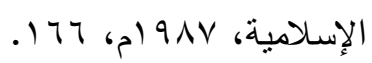

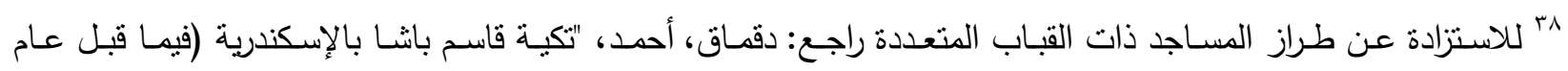

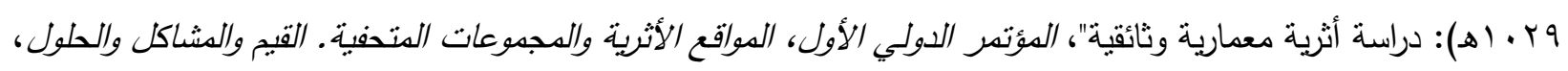

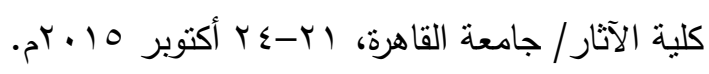

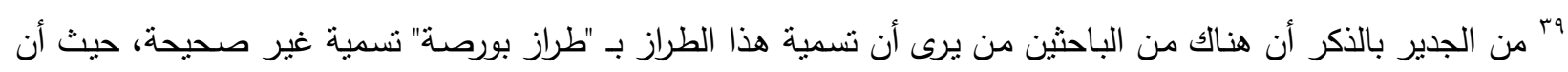

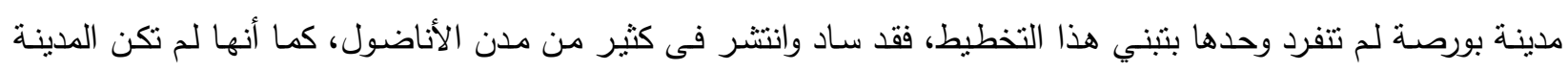

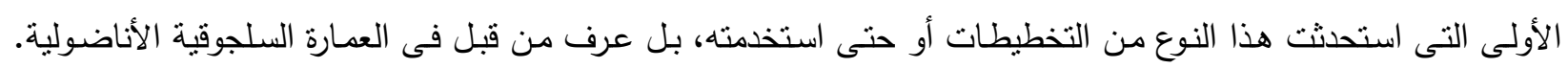

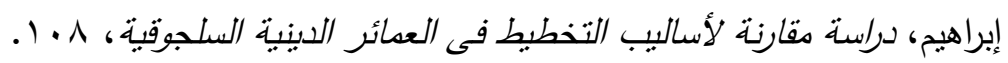


ولا يفوتتا أن نذكر أن طراز القباب المتعددة أو تغطية بيت الصلاة بمجموعة من القباب ظهر منذ فترة

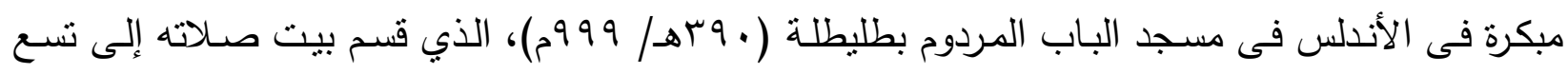

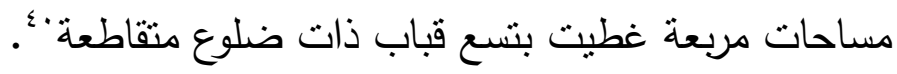

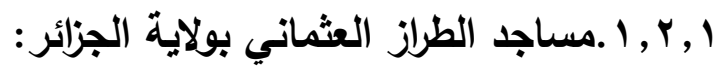
تنقسم مساجد هذا الطراز إلى نمطين:

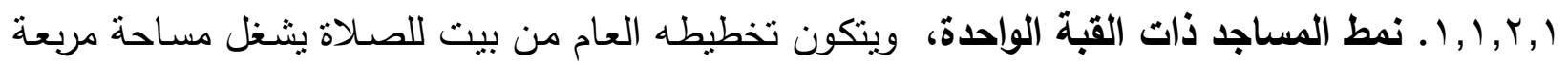

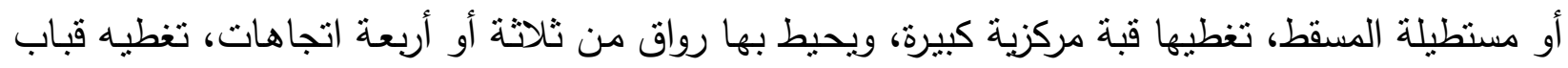

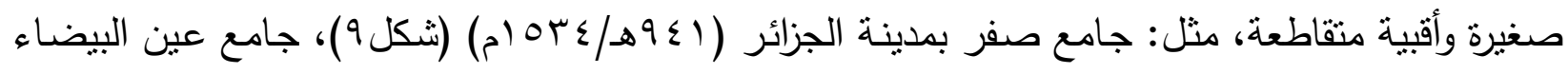

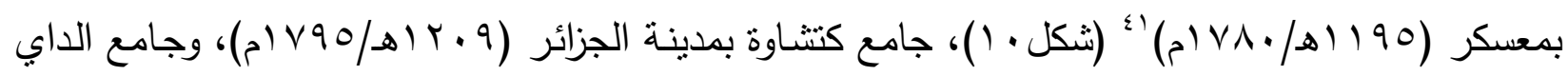

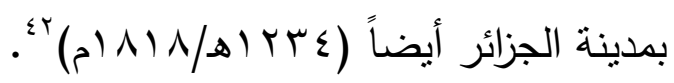
r., , , , أما النمط الثاني فمشتق من طراز المساجد العثمانية ذات الوحدتين. وتخطيطه العام عبارة

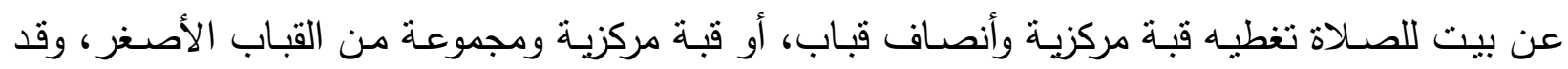

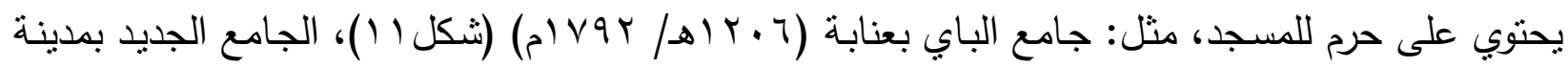

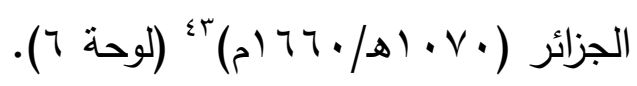

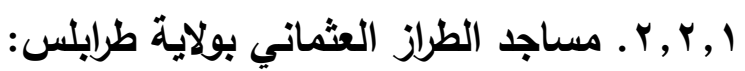
شيدت أعداد كبيرة جداً من المساجد في ولاية طرابلس على غرار الطراز العثماني، واتبعت ثلاثة أنماط

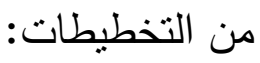

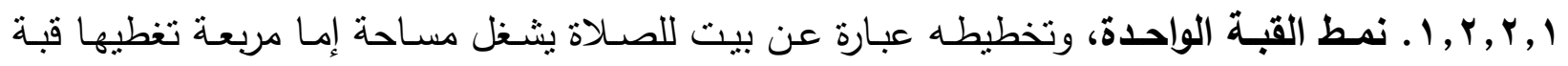
واحدة، أو مساحة مستطيلة تتقسم إلى قسمين: قسم مربع يضم المحراب والمنبر وتغطيه قبة، وقسم مسنطيل يغطيه قبو نصف اسطواني؛ وقد شغلت

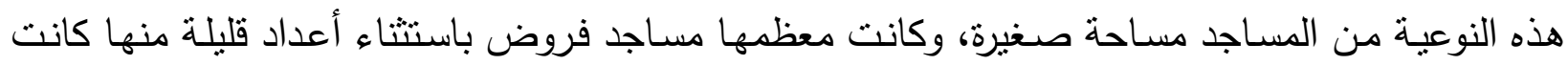

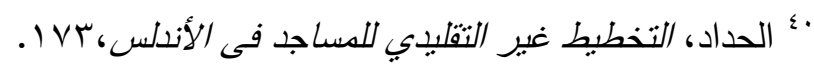

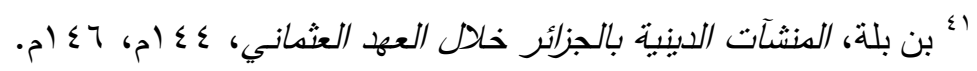

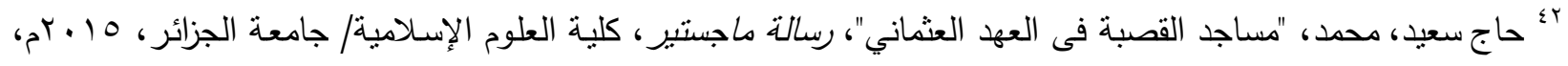

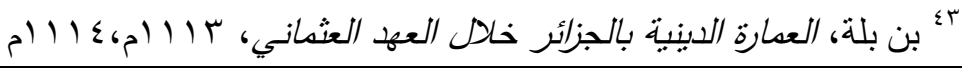




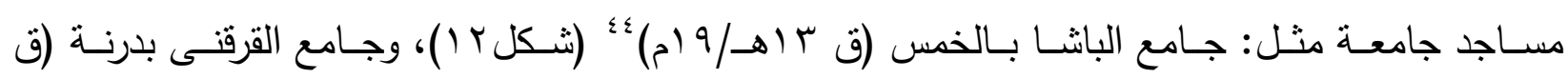

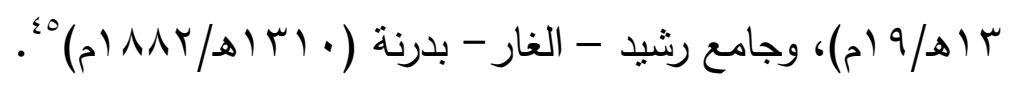

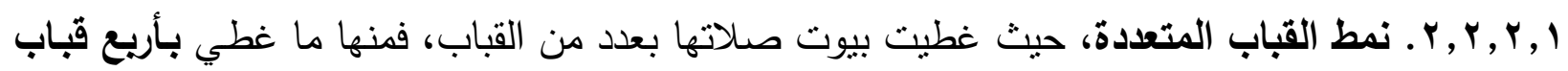

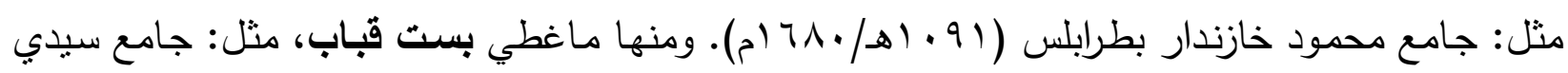

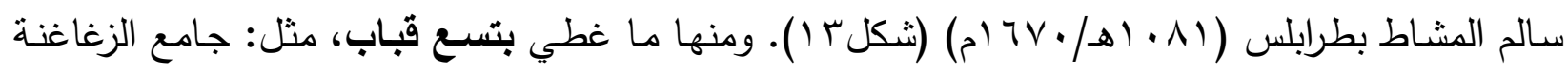

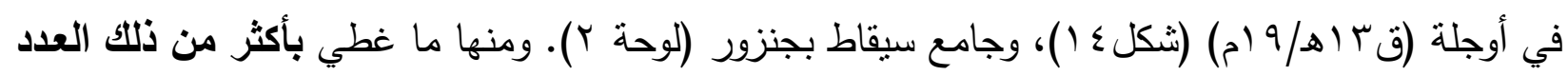

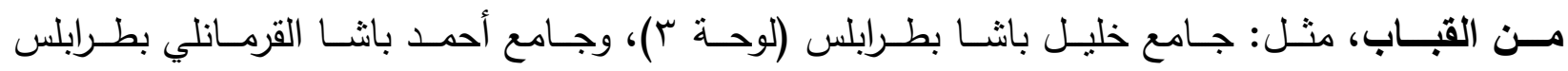

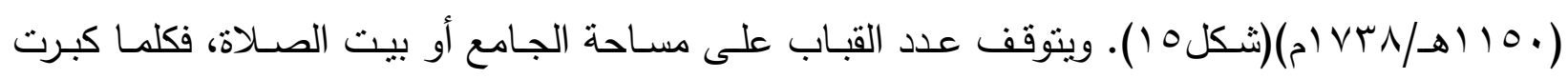

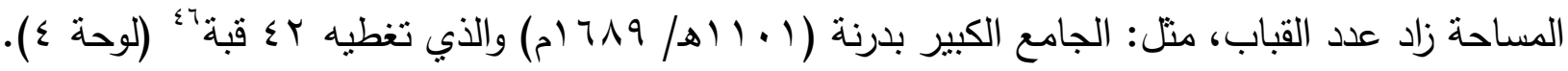

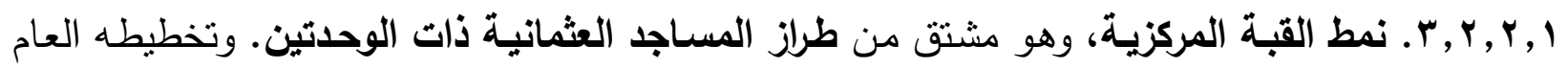

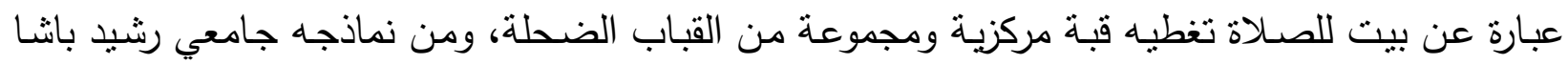

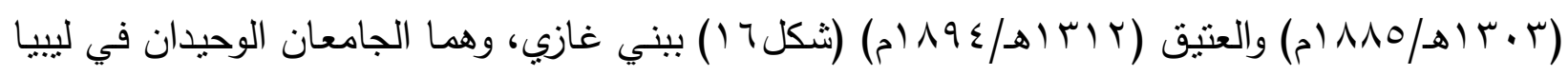

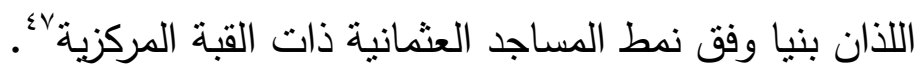

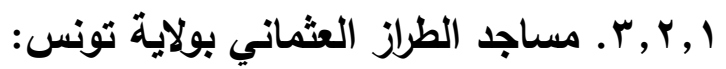

تتبع تخطيطات المساجد ذات الطراز العثماني فى تونس نمطين: الأول مشتق من نمط المساجد ذات

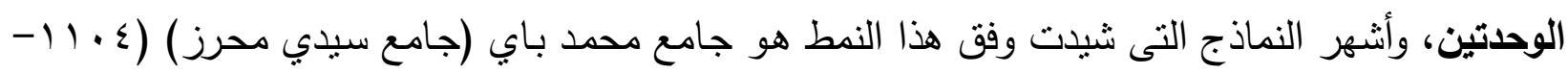

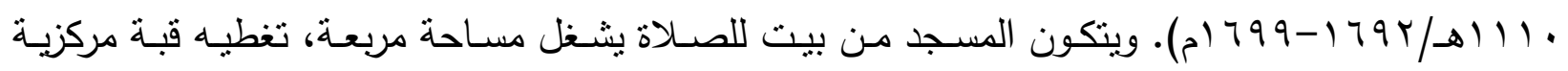

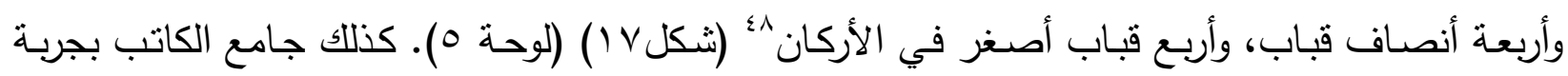

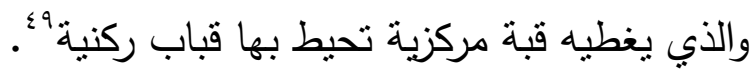

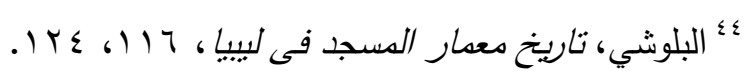

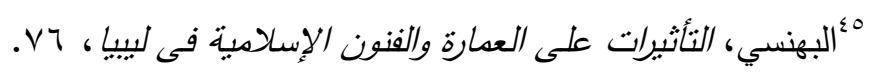

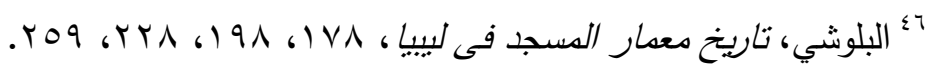

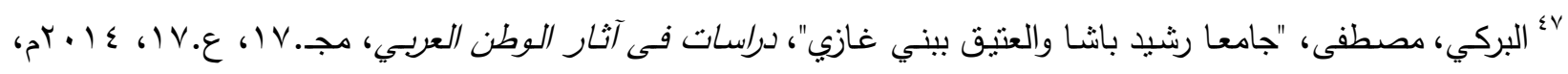

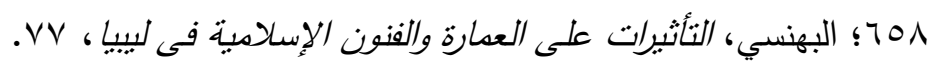

${ }^{48}$ Ben MAMI, La Mosquée M'Hammed Bey, 6.

9؛ المرابط، رياض، "جوامع ومساجد جزيرة جربة فى العصرين الحفصي والمرادي"، رسالة دكتوراة، كلية العلوم الإنسانية

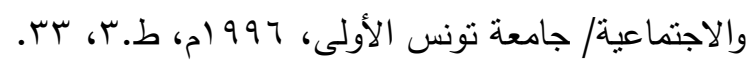


والثاني نمط المسـاجد ذات القباب المتعددة، والذي ظهر في بعض مساجد جزيرة جربة، مثل جامع

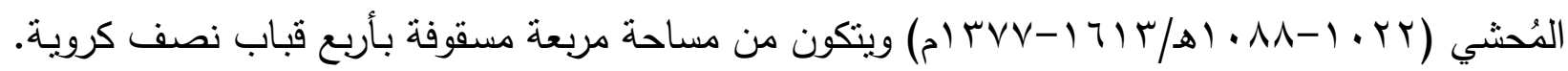

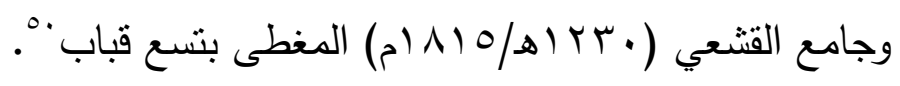
r.سمات الوحدات والعناصر المعمارية:

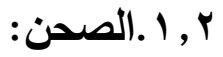
استخدم الصـن أو الفناء كعنصر من عناصر الاتصـال والحركة، وكعنصر من عناصر التهويـة

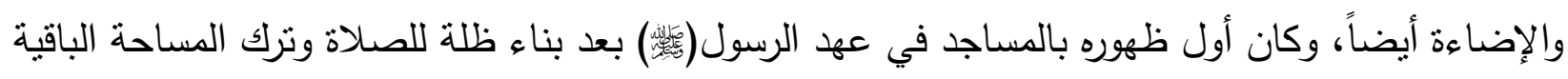

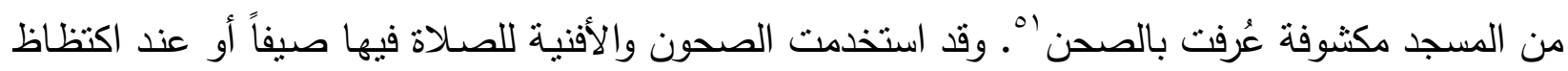
الجامع بالمصلين، وقد كانت بعض هذه الصحون تغطى بالقماش حتى يقي المصلين حرارة الثمس أو سقوط

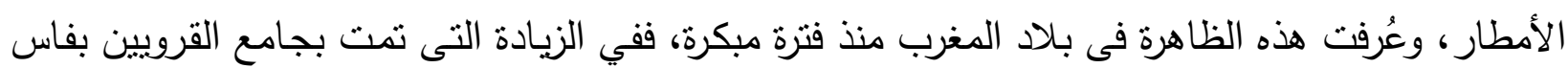

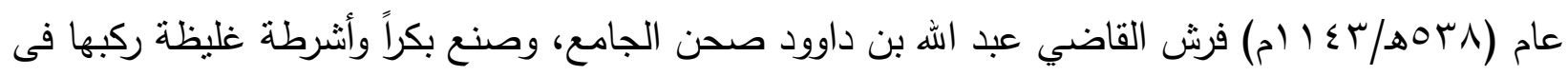

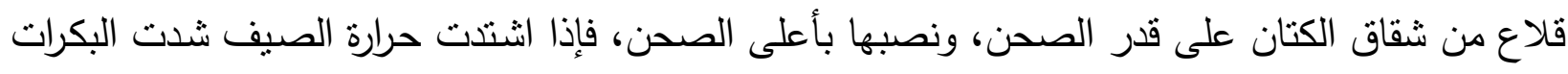

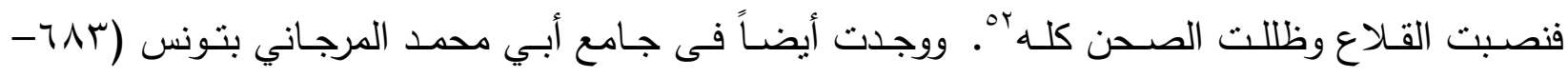

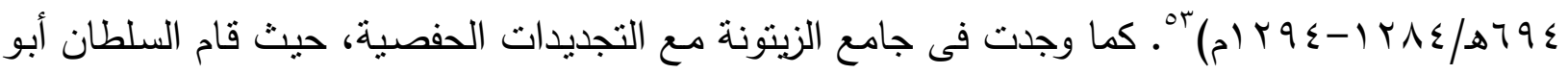

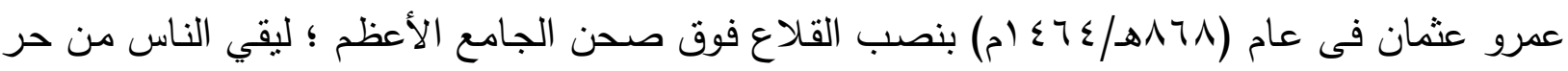
الثمس \&. 2

وقد احتوت بعض المساجد محل الدراسة على صحون وبعضها خـا منها، سواء أكانت تتبع الطراز

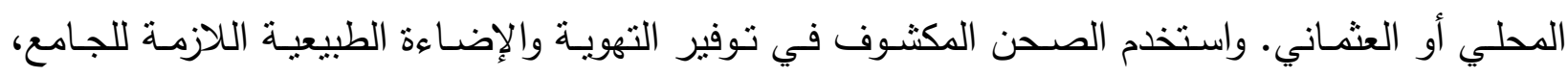

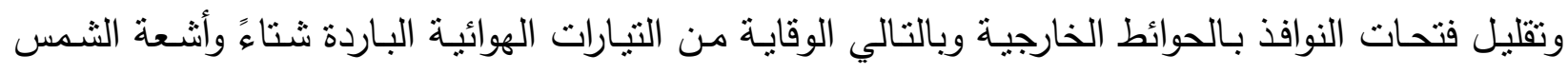

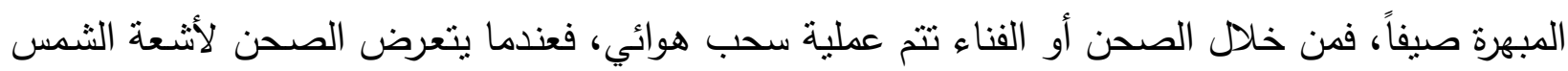

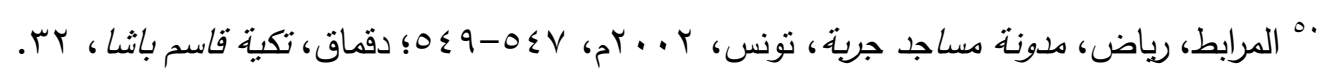

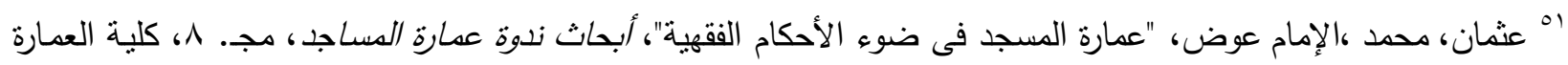

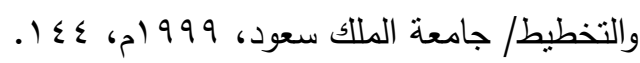

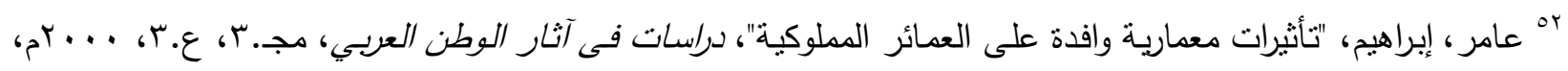
VYTHEYT

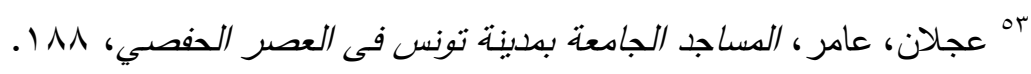

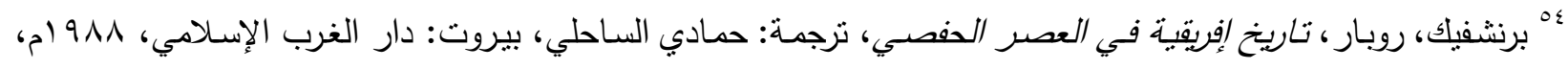


يقل وزن الهواء الساخن ويرتفع إلى أعلى من الفناء المفتوح، وفى هذه الحالة يسحب الهواء البارد من خلاد النوافذ ليحل محل الهواء السـاخن، ممـا يسـاعد على عمل اتزان حراري بين الظروف المناخية الخارجية والداخلية للمبنى، أي أن الصحن يعد بمثابة الوسيط بين كل الظروف المناخية الخارجية وفراغات أو وحدات

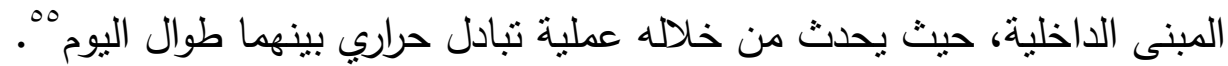

وقد زوَّد المعمار المغربي الصحون بمحاريب لتحديد اتجاه القبلة يطلق عليها المحاريب الصيفية، وظـاهرة تعدد المحاريب من الظواهر المعماريـة التى كانت موجودة بالمسـاجد المغربيـة منذ قبـل العصـر العثماني

وبشكل عام تميزت تلك الصحون بصغر مساحتها متماشية فى ذلك مع مساحات مساجدها، إضافة

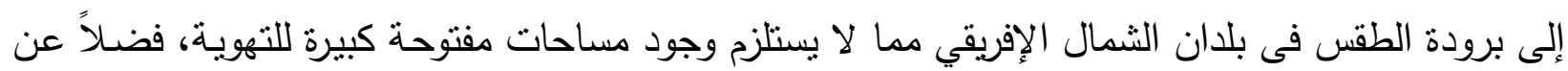
نوعية التخطيطات المنبعة فى تلك المساجد والتىى اعتمدت بشكل رئيس على بيوت الصـلاة المغلقة، فقي ولاية الجزائر احتوي كل من الجامع الكبير بمعسكر وجامع سيدي الكتاني من المساجد ذات التخطيط المحلي وجامع الباي بعنابة وجامع صفر من مساجد الطراز العثماني على صحون مستطيلة المسقط، واحتوى جامع الباشا بوهران على صحن مسقطه نصف مستدير.

وفي ولاية طرابلس احتوت معظم المساجد على صحون مستطيلة المسقط أو صحون غير منتظمة تميل إلى الاسنطالة، فبعض المساجد احتوت على صحن واحد وهي الغالبية من المساجد، وبعضها احتوى

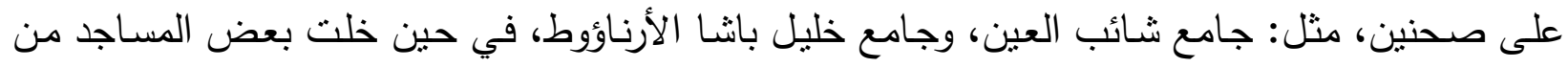

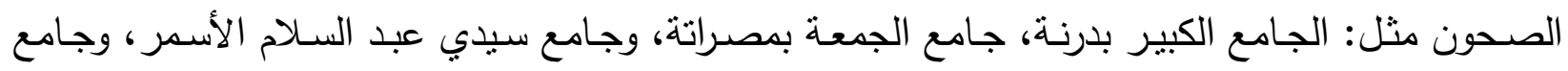

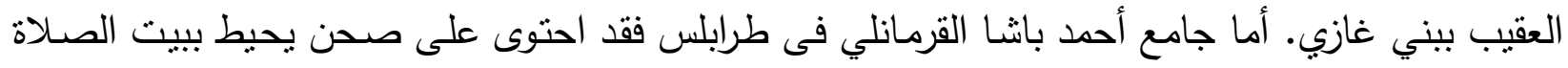

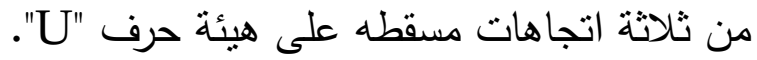

وعن ظـاهرة تعدد الصحون التى وجدت فى بعض المساجد الليبية نجد أن لها أصولها فى عمارة

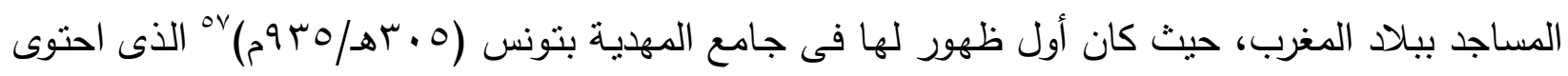

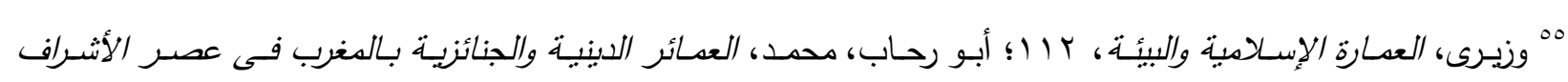

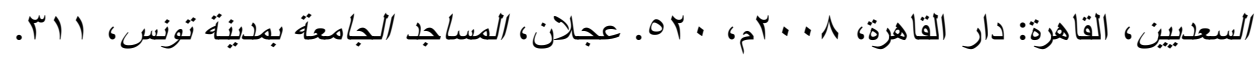

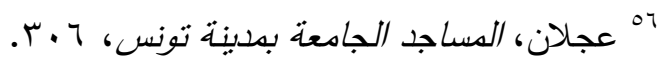
${ }^{57}$ MARÇAIS, L' Architecture Musulmane d' Occident, Tunisie, Algerie, Maroc, Espage et Sicile, Arts et Métiers Graphiques, paris, 1954, 70. 


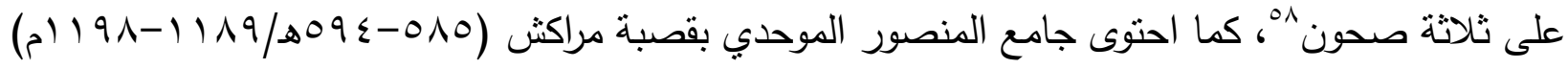
على خمسة صحون، واحتوى جامع حسان بالرباط على ثلاثة صحون 9ه، كما وجدت هذه الظاهرة بتونس فى

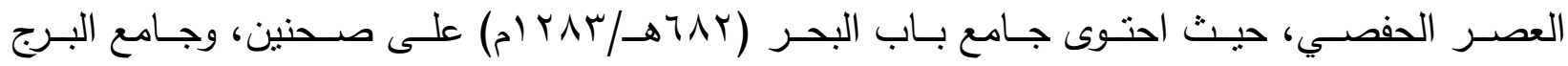

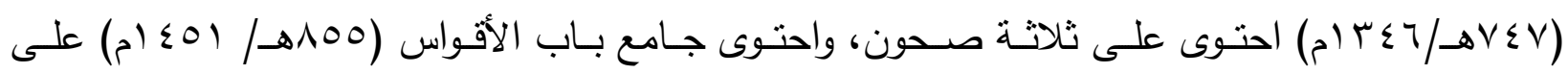
صحنين

أما فى ولاية تونس فقد احتوى كل من جامع يوسف داي، جامع حمودة باشا، جامع يوسف صاحب الطابع، وجامع سيدي محرز على صـون ثأخذ هيئة حرف "Uل"، حيث تحيط ببيت الصـلاة مـن ثـلاث جهات: الثمالية والثرقية والغربية. وهذا النمط من تخطيط الصحون ظهر لأول مرة فى تونس فى جامع

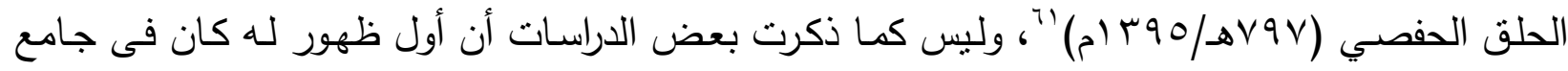
يوسف داي זّ. أما جامع الباي بالقيروان فقد احتوى على صحنين: شمالي وشرقي، يشخل كل منهما مساحة غير منتظمة أقرب إلى الاستطالة.

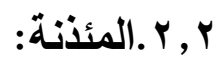

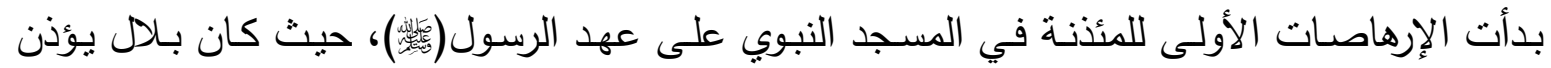
"على ظهر المسجد وقد رفع لله شئ فوق ظهره" عبارة عن كتلة بنائية مربعة من اللبن. ثم استقلت المئذنة عن المسـد حيث أصبح بـلال يؤذن من أعلى اسطوان مربعة يرقى إليها بدرجات يقال لها "المطمار" "ז"

^ه ذكر بعض الباحثين أن التخطبط الأصلي لجامع المهدية كان عبارة عن صحن واحد أوسط محاط بالأروقة، وأن ظاهرة

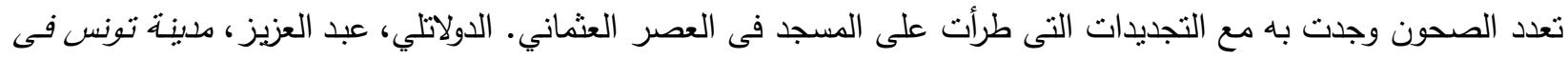

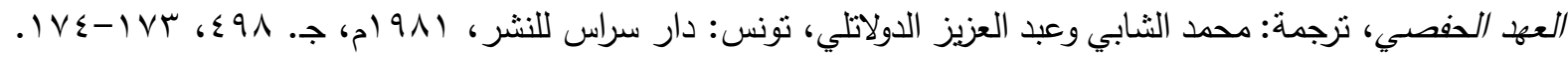

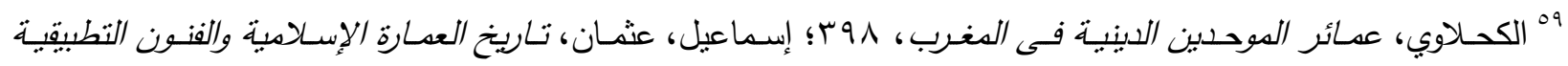

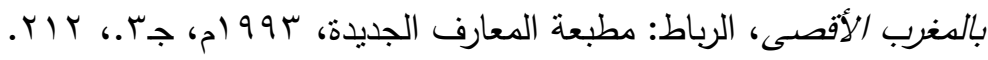

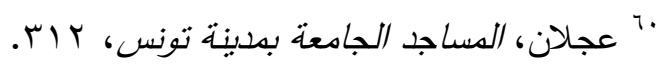

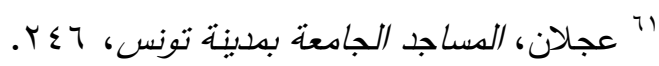

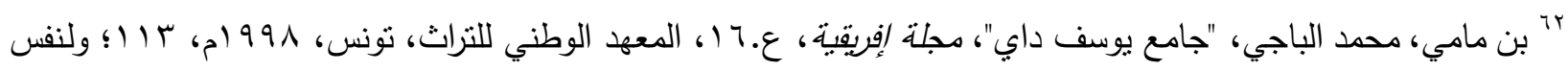

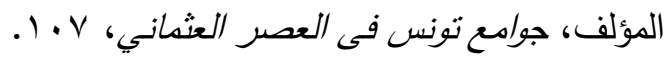

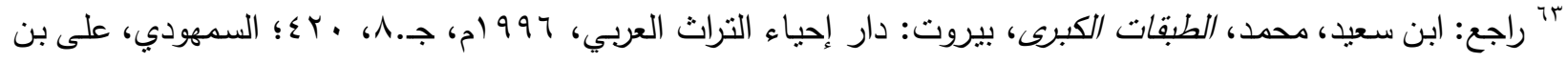

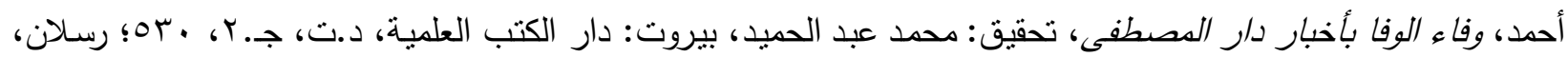

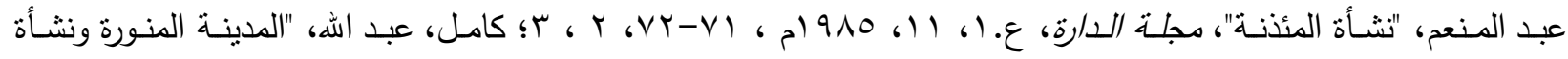

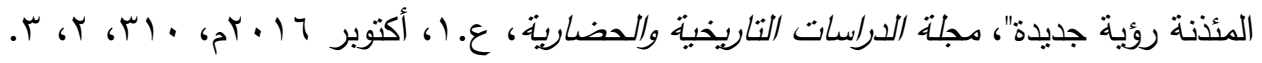


(شكل 1 ( ). ثم تطورت المئذنة وأصبحت عنصراً معمارياً متكاملاً فى عهد عثمان بن عفان، فمن مآثره "بناء

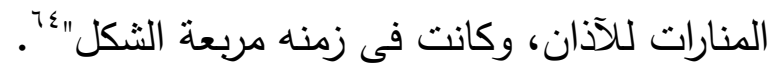

وقد حرص المعمار على الارتفاع بالمئذنة ارتفاعاً يحقق وصول صوت المؤذن إلى أقصى مسافة

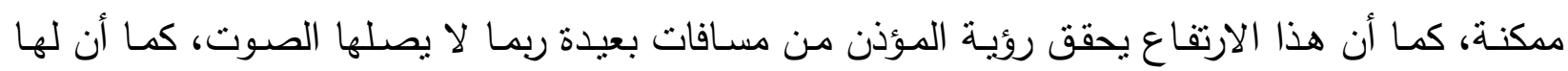

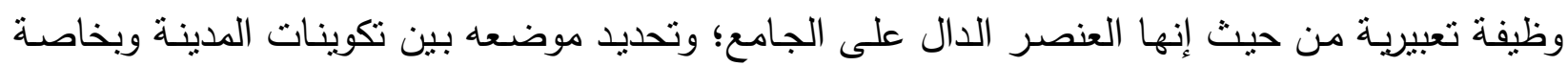

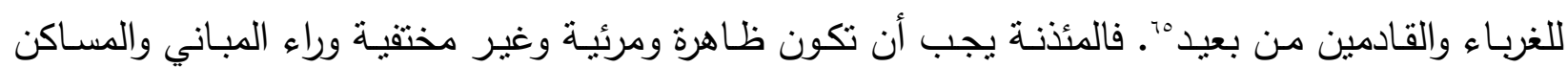

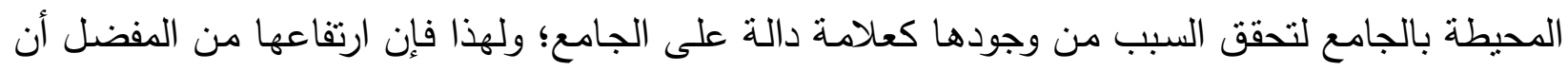

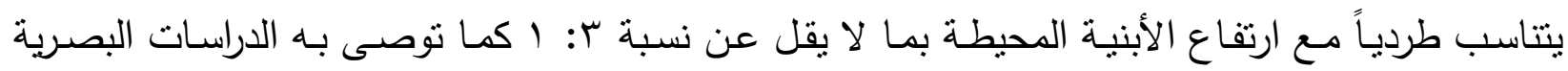

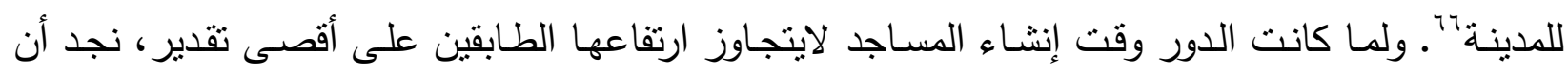
المآذن قد حققت الغرض من كونها العنصر الدال على الجامع بين تكوينات المدينة.

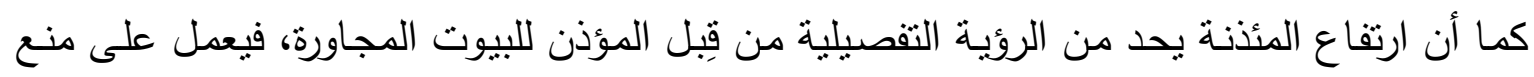

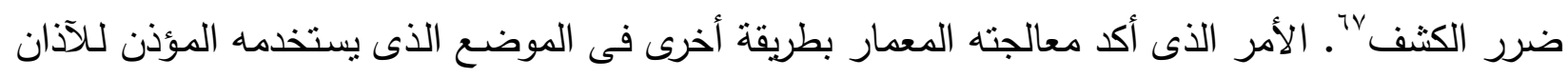

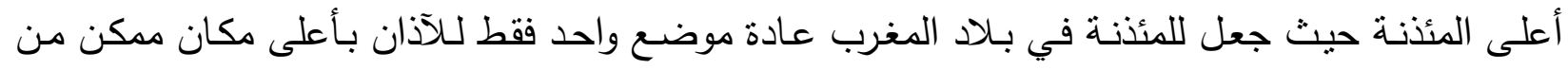

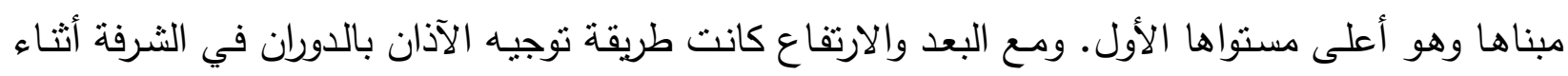

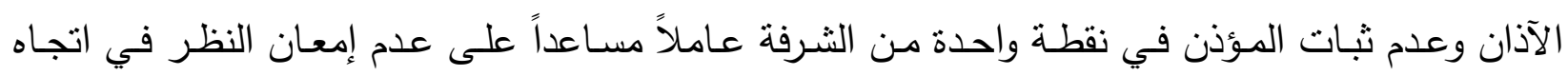

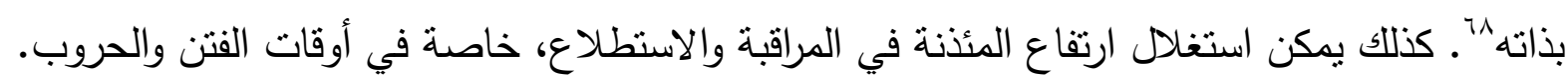
أما عن موضع المئننة بالنسبة للجامع فنجد أن ضرر الكثف وإبراز الجامع من خلال مئنته وموضع

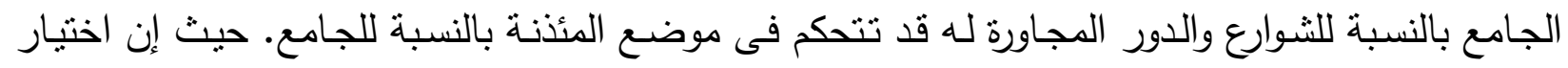

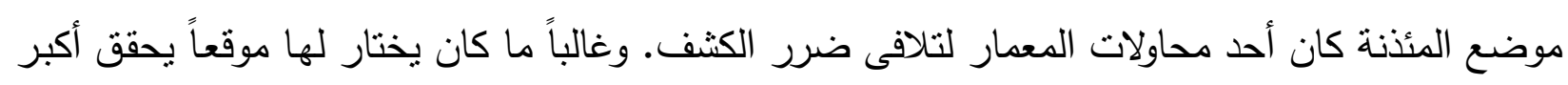

§" ابن الحسين، يحيى، غاية الأماني في أخبار القطر اليماني، تحقيق: سعيد عبد الفناح عانور، القاهرة: دار الكتاب العربي،

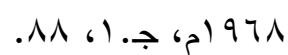

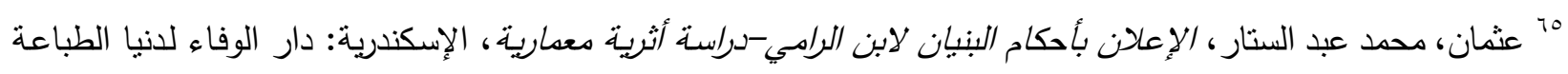

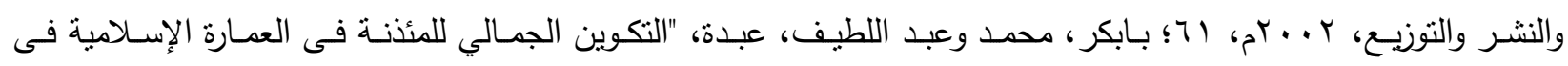

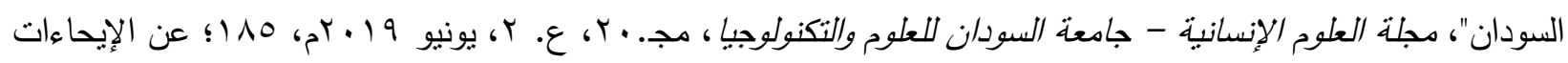

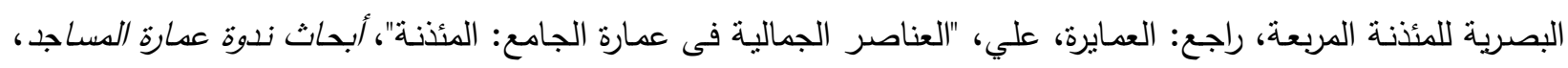

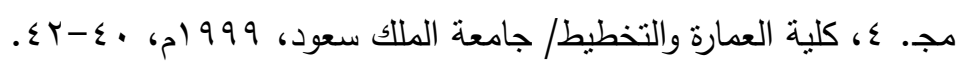

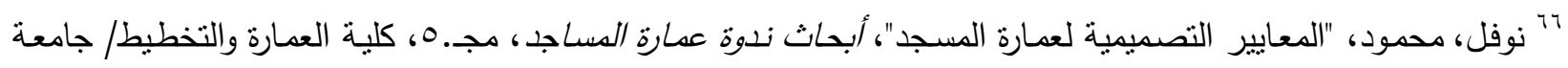

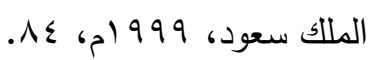

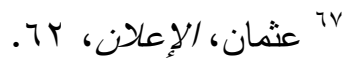

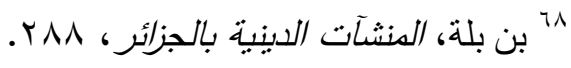


بعد ممكن عن الدور مستخلاً فى ذلك مساحة الجامع والثوارع المطلة عليها وظروف المساحات المحيطة به. يضاف إلى ذلك أن المعمار كان حريصاً على وضع المئنة خارج ساحة الجامع مجاورة له، بحيث لا تشغل أى جزء من المساحات المخصصة للصلاة تطبيقاً للأحكام الفقهية وقد تعددت أنواع المآذن، وتتوعت أشكالها، وطرزها المعمارية، ومواد بنائها، في كل قطر من أقطار العـالم الإسـامي، ففي بـلاد الثـام والمغرب والأندلس ظهرت المـآذن المربعـة الشكل، في حين انتشرت فى في مصـر نمـاذج متعددة مـن أنـواع المـآذن، مـا لبثت أن توحدت فـى العصـر المملوكي، وقد شـاعت المـآذن الاسـطوانية الثـكل بـرؤوس مدببـة (قلميـة الثـكل) عند العثــنيين، وفي إيـران ظهـرت المئذنـة المخروطيـة

وفي مساجد العصر العثماني بولايات الغرب الإسـامي ظهرت عدة أنماط من المـآذن: مآذن مربعة تتبع الطراز المحلي أو التقليدي لمآذن بلاد المغرب والأندلس، ومآذن مثمنة وأخرى اسطوانية، ومآذن تجمع بين المثمن والاسطواني، والمئذنة السلم. وتتكون المـآذن غالباً من قاعدة مربعة، يعلوها البدن الذي ينتهي بشرفة، ثم الجوسق الذى يأخذ نفس تخطيط البدن. ففي مساجد ولايـة الجزائر تبـدأ المـآن بقاعدة مربعة يعلوهـا بدن المئنـة الذي تتوعت أثنكاله، حيث وجدت مـآذن ذات بـن مريـع، مثل: مئنـة الجامع الجديد بمدينة الجزائر (لوحة \)، ومئذنة الجامع الكبير

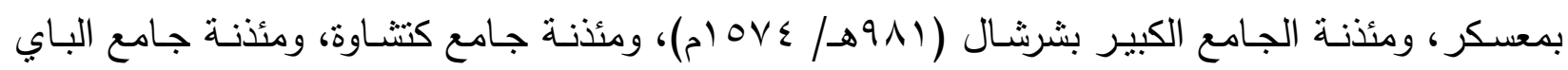
بوهران، ومئذنة جامع سيدي عقبة ببسكرة' . ومـآذن ذات بلن مثثن، مثلما فى مئننة جامع صفر ، ومئذنة جامع الأخضر بقسنطينة، ومئذنة جامع عين البيضاء بمعسكر ، ومئذنة جامع الباشا بوهران، ومئذنة جامع القصبة البراني، ومئذنة جامع الداي ومئذنة جامع الجيش بقصبة مدينة الجزائر • ومـآذن ذات بلن اسطواني وهي التى نجد لها مثالاً وحيداً فى الجزائر والمتمنلة فى مئننة جامع صالح باي بعنابة. ومـآذن ذات بدن بـن

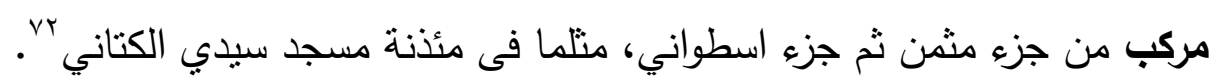

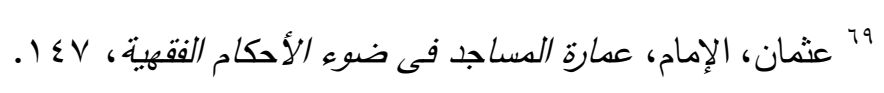

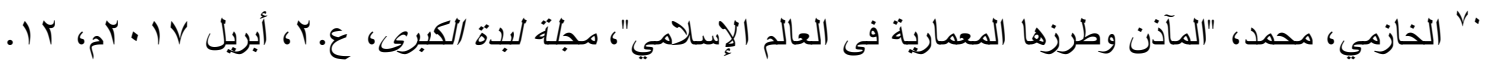

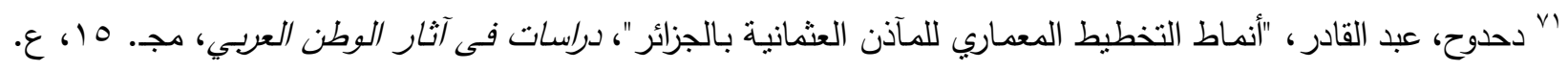

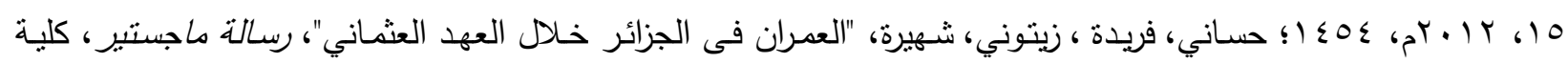

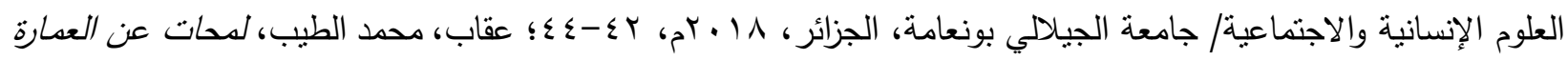

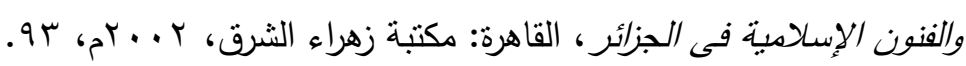

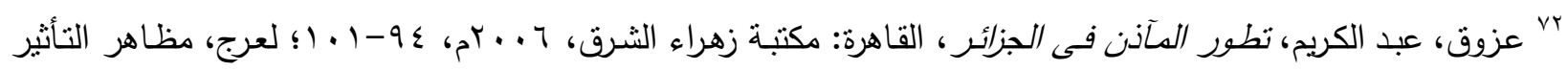

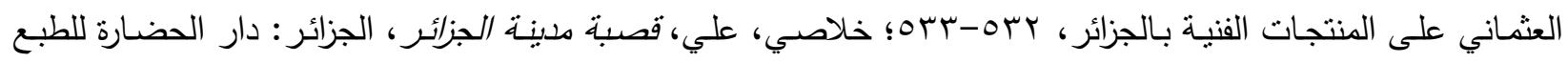

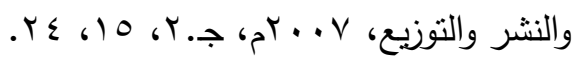


وفي ولاية طرابلس تتوعت المآذن، حيث وجدت مآذن مريعة، مثل: مئنة جامع القبطان، مئنة جامع

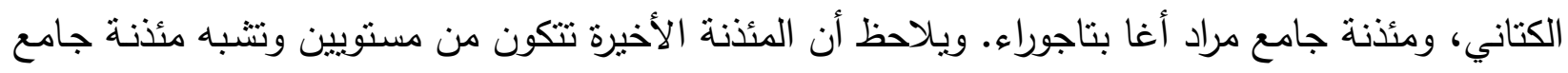

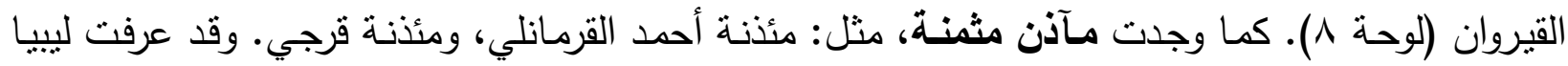

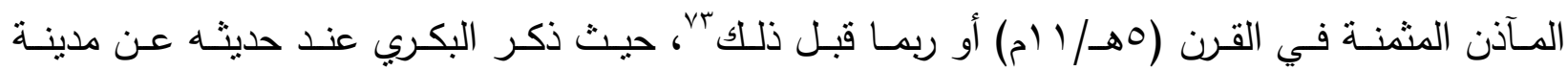

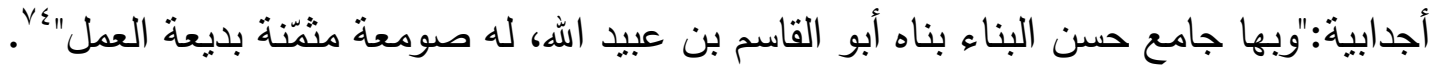

وظهرت المآذن الاسطوانية فى كثبر من المساجد منها: محمود خازندار، سالم المشاط، درغوت باشا،

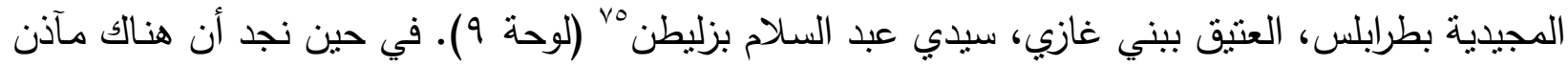
تتكون من سلم فقط، تُعرف بِ"المئذنة السلم"، وعادة ما يكون هذا السلم محازياً لأحد جدران المسجد، كما في

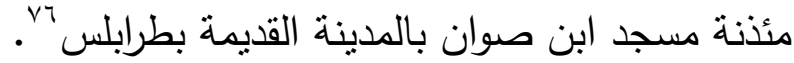

ونمط المئذنة السلم مرحلة بدائية في تاريخ عمارة المآذن، وكانت أولى نماذجها "المطمار" في مسجد الرسول (شكل ^1 (). وعلى الرغم من ذلك فإن هذا النوع كتب له الاستمرار في بعض البلاد الإسلامية ومنها

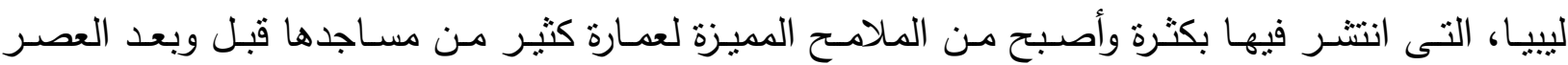
العثماني

كما وجد نوع من المئننة السلم عبارة عن برج صغير فى أحد أركان المسجد أعلى السطح، أثبه ببرج

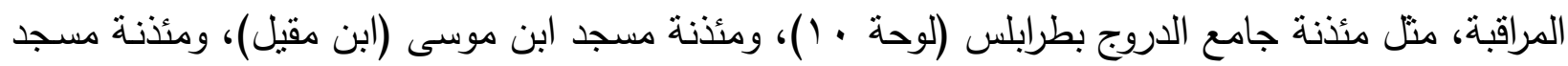

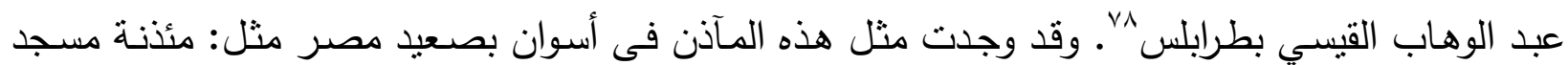
الملاقطة، ومئذنة مسجد كفر العبلاب، ومئذنة مسجد الخطارة"ra. وهذه المآذن شبيهة بأبراج المراقبة الصغيرة

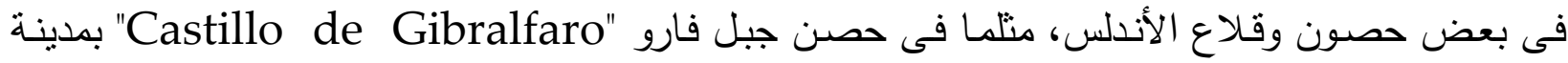
مالقة، وفى قلعة مروان "Castelo de marvão" بالبرتغال ‘.

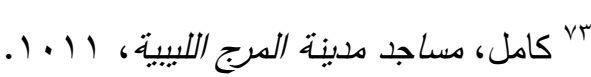

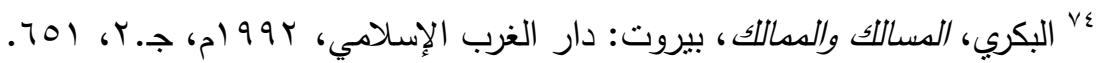

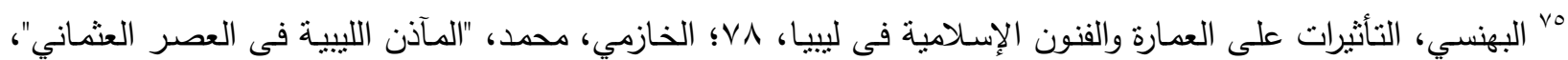

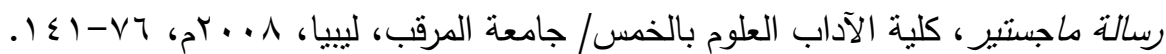

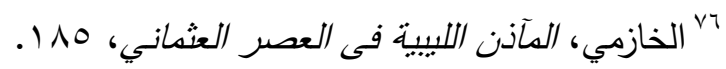

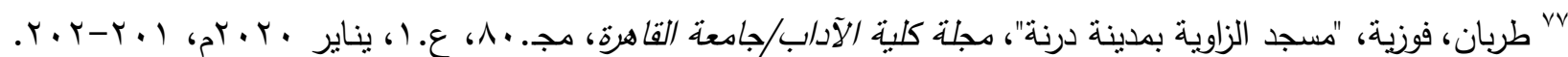
والمئنة السلم في هيئتها ووضعها هذه وجدت في بعض مساجد بلاندان الأناضول في العصر السلجوقي، وكان بطلق عليها

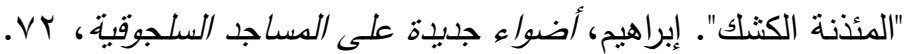

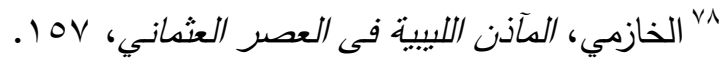

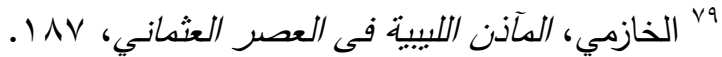
${ }^{80} \mathrm{http}: / /$ arquitecturaurbanismo-usaz.blogspot.com/2014 1001 archive.html Accessed 28/01/2021 . 
وفي ولاية نونس ظهرت المـآذن المريعة في جامع الباي بالقيروان، وفى جامع سيدي محرز بمدينة

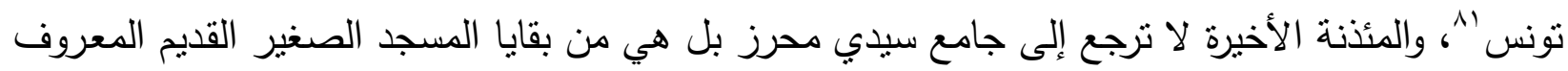

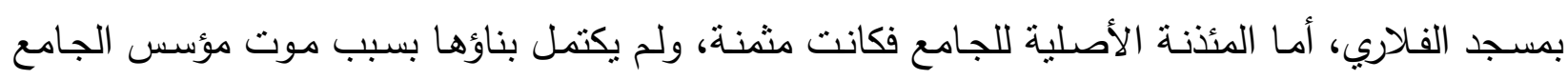
محمد بـاي وقتل خلفه أخيـه رمضـان بـاي ك^؛ كمـا وجدت المـآذن المثمنـة فى كل من جامع يوسف داي (لوحة ( ())، جامع حمودة باشـا (لوحة ب ( )، الجـامع الجديد، جامع صـاحب الطـابع، والجـامع الكبير فى

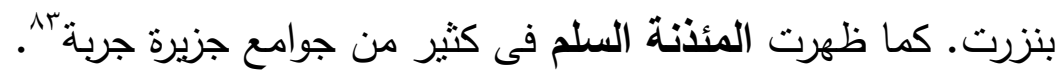

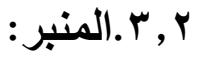

ظهر المنبر كعنصر مهم فى المساجد الجامعة ومصليات العيد، وغالباً ما كان يصنع من الخشب كما كان الحال فى المسجد النبوي، أو يبنى بالطوب أو الحجر كما ظهر فى عهد الخليفة عثـان فى مصلى العيد بالمدينة المنورة، أو يبنى كله من الرخام أو الحجر كما في بعض منابر العصرين المملوكي والعثماني. واهتم المسلمون بالمنبر اهتماماً بالغاً، وتطور فى العصر الأموي حتى أصبح يتكون من تسع درجات بدلاً

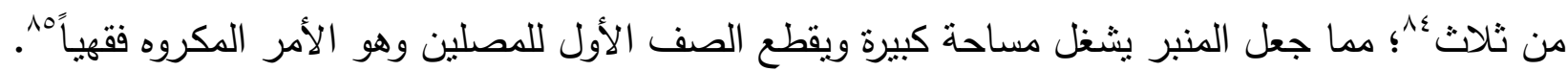
لذلك ظهرت المنابر المتحركة، حيث كانت المساجد فى الغرب الإسـامي قبل العصر العثماني تحتوي على منابر خثبية متحركة، ولم تتتشر المنابر البنائية الثابتة إلا مع قدوم العثمانبين. ولم يجد العثمانيون غضاضة في بناء منابر ثابتة، حيث رأى الفقهاء أنه "بستحب جعل المنبر فى الجامع لأجل الخطبة بشرط ألا يضيق على المصلين"، ورأوا أن اتخاذه سنة مجمع عليها`^؛ لذلك شرع العثمانيون فى بناء منابر ثابتة فى مساجدهم التى شيدوها فى الغرب الإسـامي، خاصـة وأن هذه المنابر لم تكن بالضخامة التى تضيق على المصلين، وتتاسب حجمها مع حجم بيوت الصـلاة بنلك المساجد. ولم يكتف العثمانيون بذلك بل بدلوا بعض المنابر

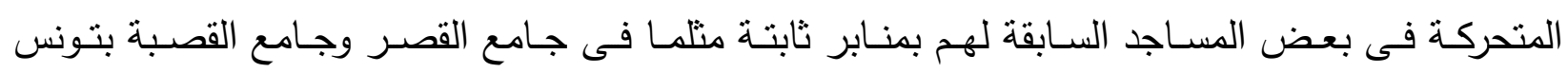

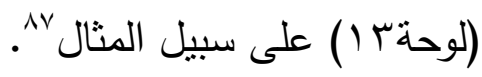

81 BeN MAMI, La Mosquée M'Hammed Bey, 13.

r^ ابن الخوجة، محد،، تاريخ معالم التوحبد في القديم وفي الجديد، تحقيق: الجيلاني يحيى ،حمد الساحلي، بيروت: دار الغرب الإسلامي، ط.ب، 919 ام، 1110-110.

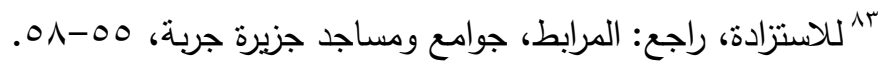

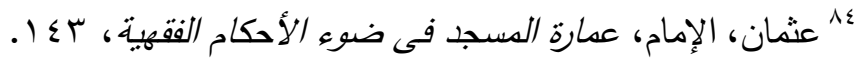
هـ الزركثى، بدر الدين، إعلام الساجد بأحكام العساجد، تحقيق: أبو الوفا المراغى، القاهرة: المجلس الأعلى للشئون الإسلامية،

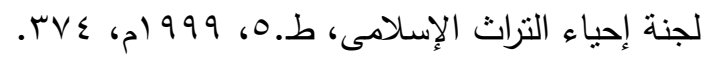

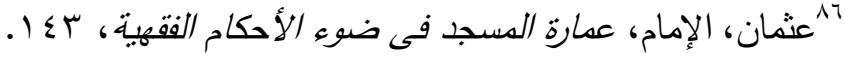

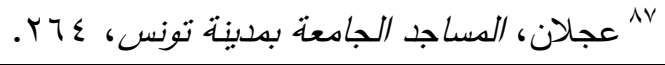


وأدى ظهور المنابر الثابتة على حساب المنابر المتحركة إلى اختفاء بيت المنبر الملحق خلف جدار

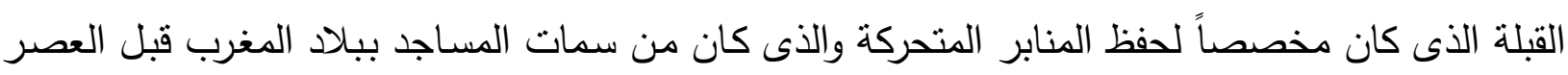
العثماني.

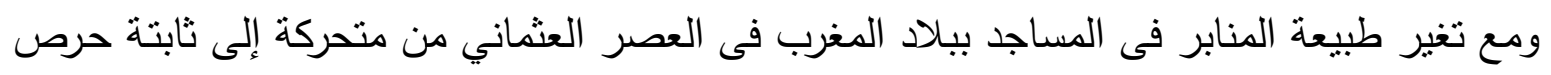

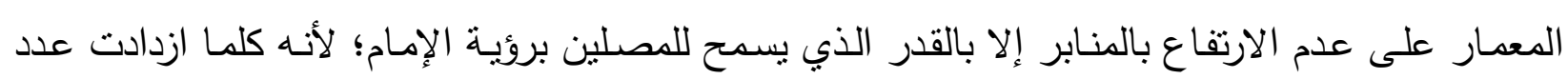

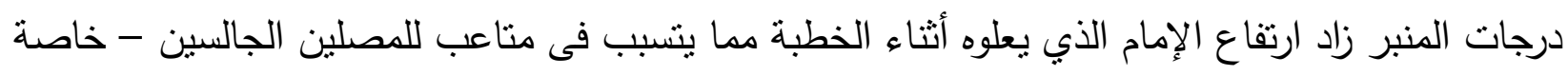
الذين بالصفوف الأولى - نتيجة رفع رؤسهر طوال الخطبة. وقد تباينت مواد بناء تللك المنابر ما بين الحجر والرخام والخشب. ففي مساجد ولاية الجزائر تتوعت

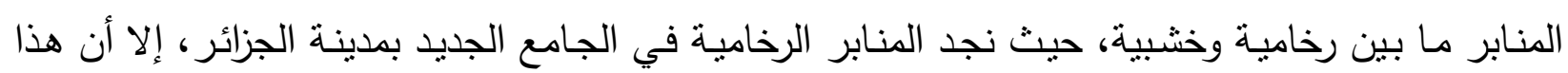

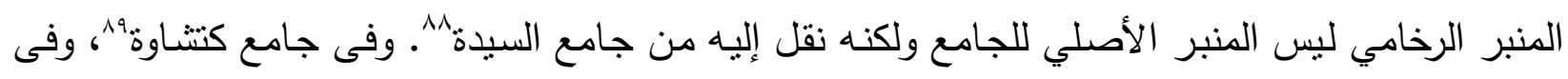

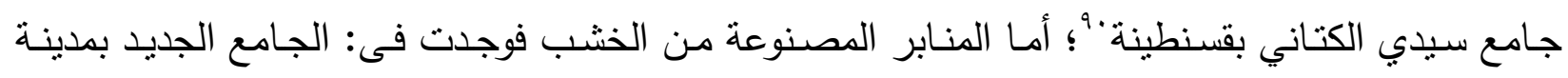

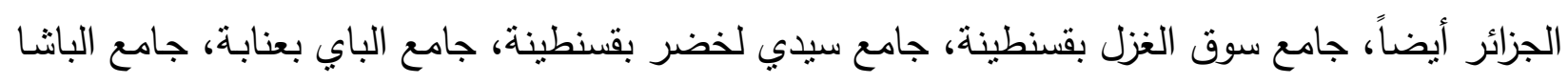

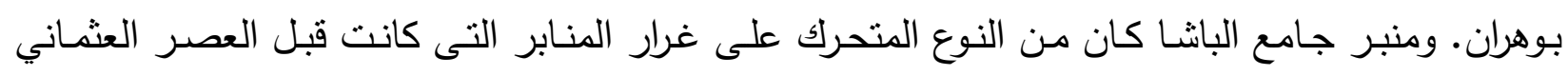

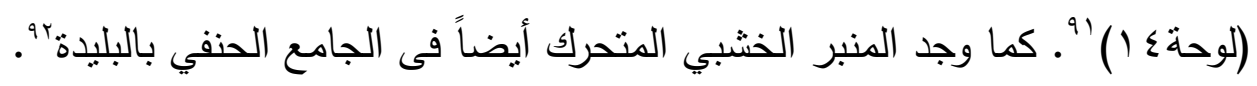

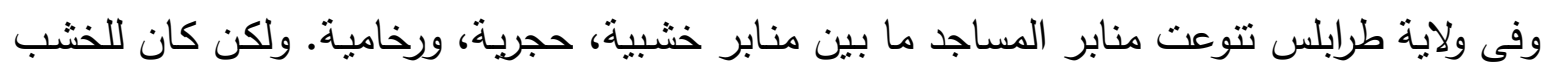

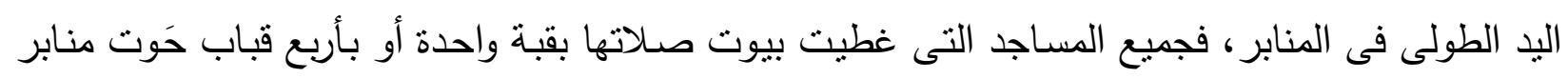

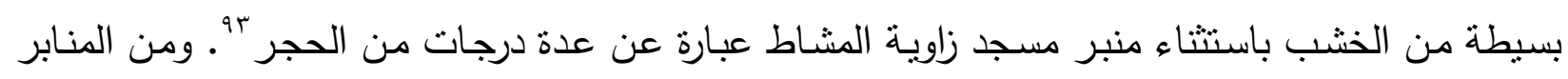

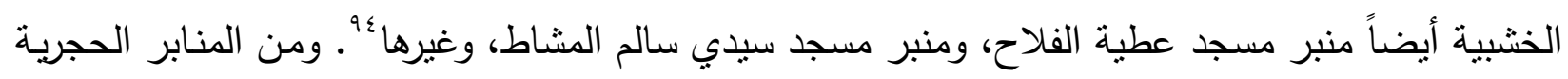

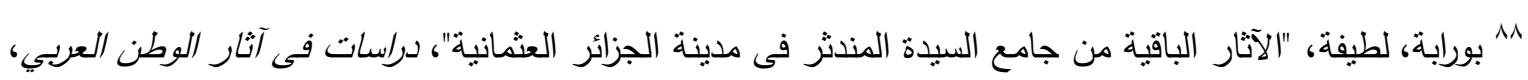

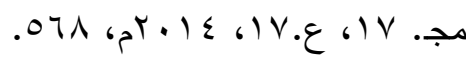

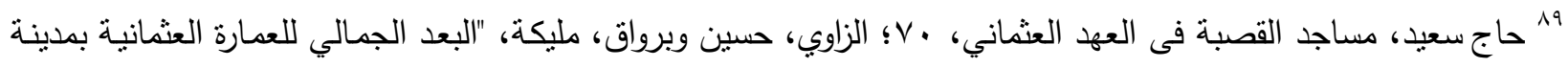

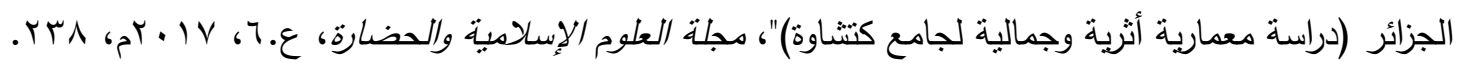

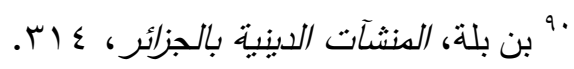

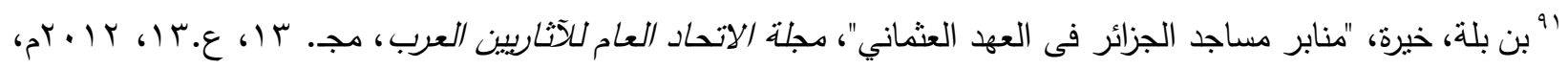


منبر جامع الخروبة (لوحة ه (1)، ومنبر جامع محمد شائب العين. أما المنابر الرخامية فنجد أمثلتها فى منبر جامع القرمانلي، ومنبر جامع مصطفى قرجي وفي ولاية تونس جاءت جميع منابر مساجدها من النوع الثابت، وبنيت منابر : جامع يوسف داب، جامع محمد باي المرادي، الجامع الجديد، وجامع يوسف صاحب الطابع بمدينة تونس من الحجر وكسيت بلوحات

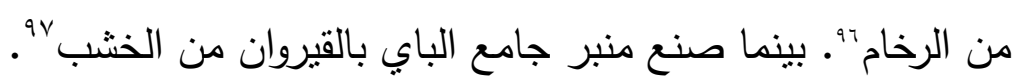
r

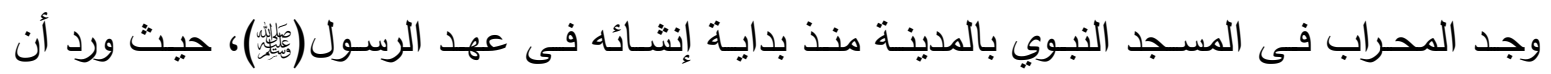
الصحابة عند بناء محراب المسجد "صفوا النخل قبلة له، وجعلوا عضادتيه من حجارة"، وهو ما يعنى معمارياً

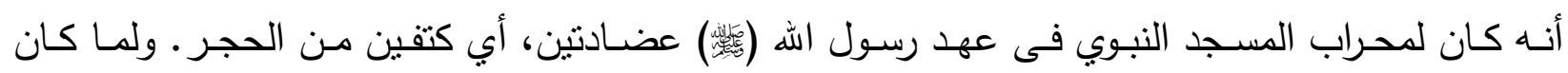
المحراب مسدوداً من الجهة الخارجية فإن ذلك يعنى أنه كان فى هيئة دخلة أو حنية، أي أنه كان مجوفاًُهـ ومن أقدم النماذج الباقية للمحاريب المجوفة محراب جامع عقبة بالقيروان ( • هـ/ • Vדم)، ومحراب مسجد قبة هئة

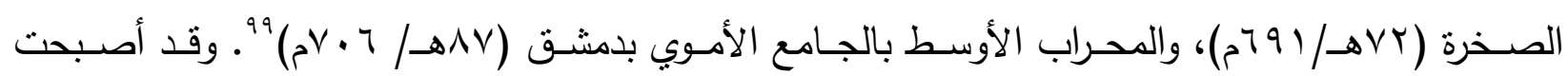
المحاريب من العناصر الرئيسة فى أروقة الصـلاة التى تحدد اتجاه القبلة فى مساجد العالم الإسـلامى شرقاً وغرباً. وثتوعت تخطبطاتها، وأثكالها، وزخارفها.'. ففي مساجد العصر العثماني بالغرب الإسـامي تنوعت تخطيطات وأشكال المحاريب. وعربا.

ץ, ـ , ا ـ من حيث المظهر الخـارجي: ففي ولايـة الجزائر نجد أن محاريب المساجد التى بنيت على الطراز العثماني لها حنية بارزة عن جدار القبلة؛ وذلك يرجع إلى عاملين: هما مدى عمق حنية المحراب، ومدى سمك جدار القبلة. ومن الملاحظ أن محاريب تلك المساجد امتازت بعدق حناياها على غرار باقي مساجد الغرب الإسـلامي '.'. وسـاعد عمق حنيـة المحراب على تضخيم صـوت الإمـام ليصل إلى أكبر قدر من

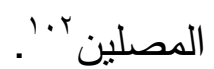

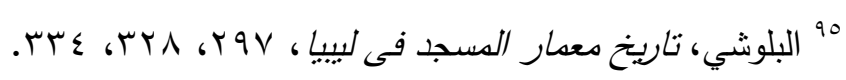

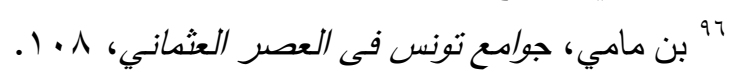

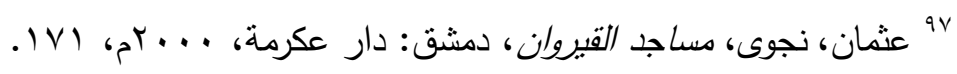

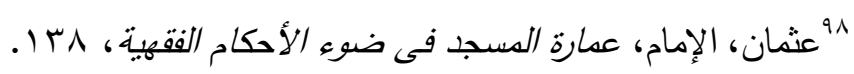

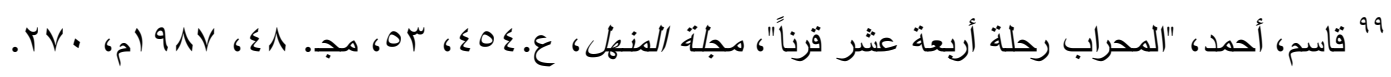

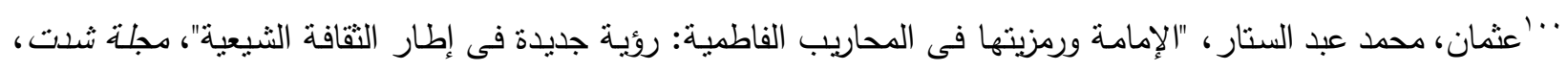

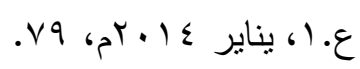

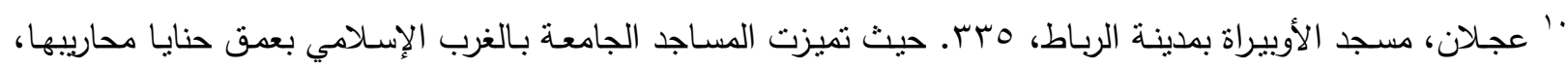

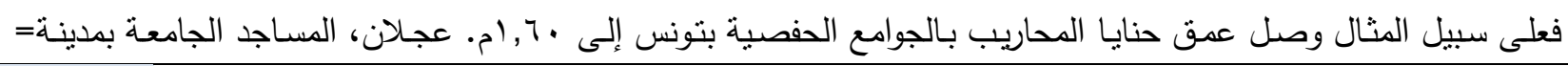


كما يتيح هذا العمق مع اتساع فتحة المحراب للإمام أن يقف داخل حنية المحراب وفى نفس الوقت يكون مرئياً من قبل المصلين، وبالتالي يوفر خلفه صفاً للمصلين، فيعدل بذلك على زيادة استيعاب رواق القبلة للمصلين. وقد استطاع المعمار أن يحقق هذا العمق فى المحراب عن طريق البروز بحنية المحراب خارج جدار القبلة.

أمـا المسـاجد التي بُنيت على الطراز المحلي فمحاريبها بارزة أيضـاً عن جدار القبلة باستثناء جامع القصبة الخارجي بمدينة الجزائر ، وجامع سيدي لخضر بقسنطينة، وجامع ابن سعدون بالبليدة؛ وذللك يرجع إلى: بالنسبة لجامع القصبة الخارجي فلم تبرز حنية محرابه بسبب سمك جدار قبلته. أما جامع سيدي لخضر فلم تبرز حنية محرابه لوجود كتلة المحراب بارزة داخل بيت الصـلاة. فى حين لم تبرز حنية محراب جامع ابن سعدون لأنها غير عميقة، إذ بلغ عمقها فقط 07 , •مّ'؛ أما محراب الجامع الجديد بمدينة الجزائر فهناك من الدراسات ما صنفت حنية محرابه على أنها غير بارزةء'، وبالرجوع إلى مخططات المسجد نجد أن حنية محرابه بارزة عن جدار القبلة، إلا أن هناك حجرات تقع خلف جدار القبلة تحول دون رؤية بروز المحراب من خارج المسجد.

=تونس، 101؛ وفي المغرب الأوسط وصل عمق حنايا المحاريب إلى 90, ام مثلما فى محراب الجامع الجديد بمدينة الجزائر.

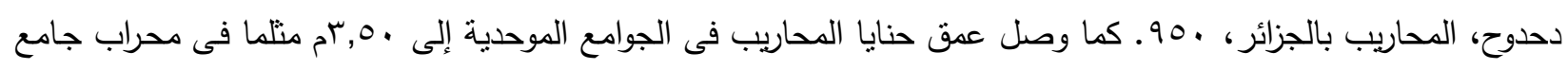

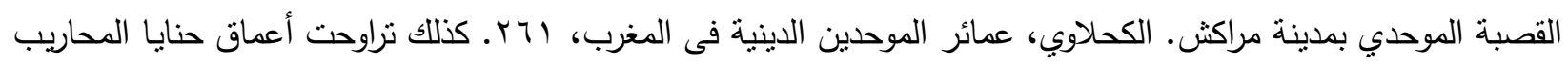

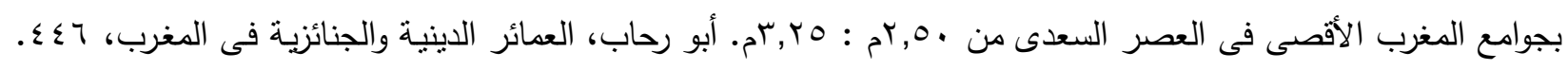

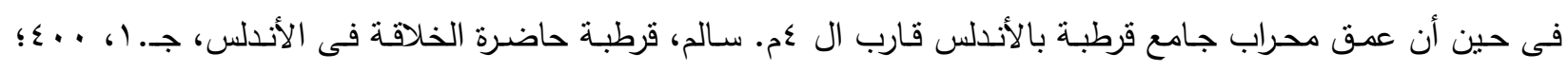

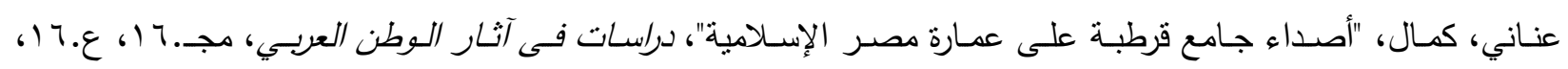

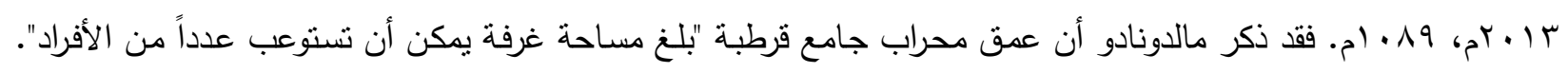

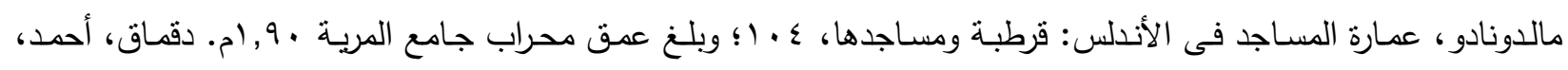

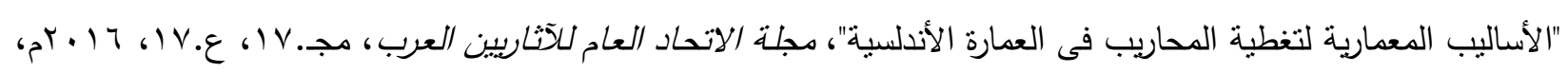

0 0

TORRES BALBÁS, L:.« La mezquita mayor de Almería, Cronica Arqueologica de la Espana», Musulmana 5, 1981, 255-256.

r.1 عنمان، الإمام، عمارة المساجد فى ضوء الأحكام الفقية ، به 1؛ مهران، على، "المعايير التخطيطية والأسس التصميمية

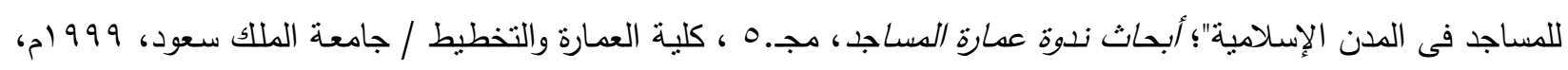

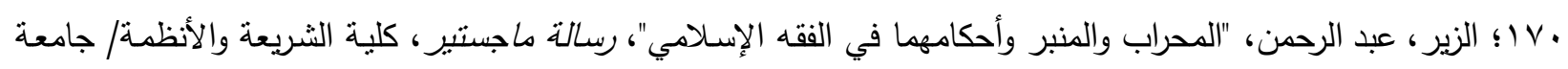

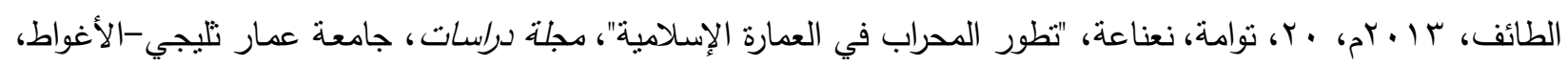

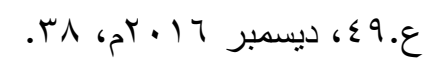

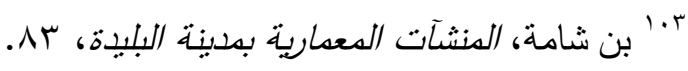

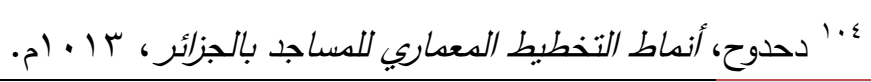


وقد تتوع شكل بروز حنية المحرب من الخارج، فمنها ما اتخذ هيئة نصف دائريـة، مثلما في: جامعي صفر وكتشـاوة بمدينة الجزائر ، ومسجد سيدي إبراهيم بالمنصورة، وجامع الغزل بقسنطينة. ومنها مـا اتخذ هيئة مضلعة، مثل محاريب جوامع: علي بتثين بمدينة الجزائر، عين البيضاء بمعسكر • ومنها ما اتخذ هيئة مستطيلة منل: محراب الجامع الجديد بالجزائر العاصمة، ومحراب جامع سيدي الكتاني بقسنطينة. وفي ولايـة طرابلس فإن أغلب المحاريب عبارة عن كتلة بنائية تبرز عن سمت جدار القبلة للداخل، وتجويف المحراب داخل هذه الكتلة، وهو ليس عميقاً بداخلهاه.'. لذلك فإن جل حنايا المحاريب ليس لها بروز خارج جدار القبلة باستثناء بعض المساجد منل: جامع أحمد باثـا القرمانلي، وجامع يدر ، وجامع محمود خازندار بمصراته لمحاريبها بروز مستطيل خارج جدار القبلة. فى حين أن مسجد حمد الشتيوي بالمرج له بروز نصف دائري.

وفي ولايـة تونس: فقد وجدت الحنايا البارزة للمحاريب فى كل من: جامع حمودة باشـا والجامع الجديد بمدينة تونس، وأخذ بروز كليهما شكل نصف دائري. وفي جامع الباي بالقيروان والجامع الكبير ببنزرت اتخذ بروز حنية المحراب شكل مستطيل.

r , צ , . . من حيث المظهر الداخلي: فقد تنوعت مساقط حنايا المحاريب من الداخل، ففي ولاية الجزائر وجدت محاريب ذات حنايا نصف دائرية، وهو النمط الأكثر استعمالاً فى محاريب مساجد الجزائر ؟1.، مثل: محراب جامع كتثاوة، ومحراب جامع القصبة الداخلي بمدينة الجزائر ، ومحراب جامع الكتاني (لوحة 7 ( ). ويعد التخطيط النصف دائري هو الأقدم في تصميم المحاريب، سواء المشرقية أو المغربية، ومن أمثلته

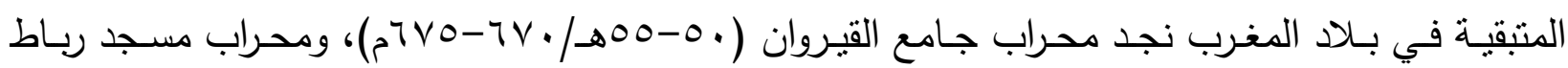

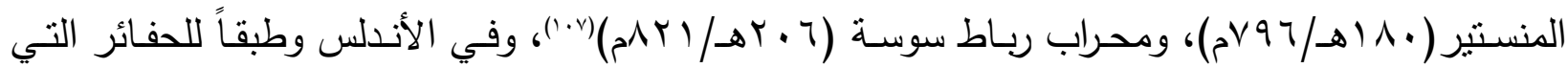
أجريت في أرضية زيـادة عبد الرحمن بن الحكم بجامع قرطبة، نجد أن محراب هذه الزبـادة كان نصف

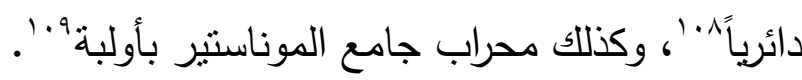

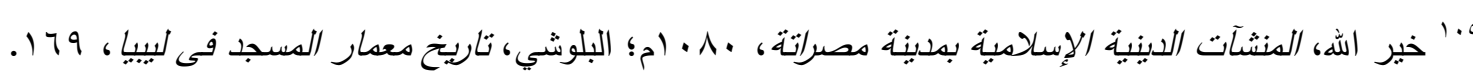

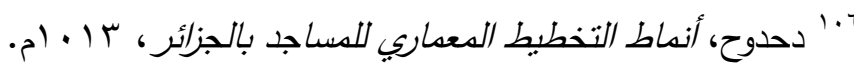

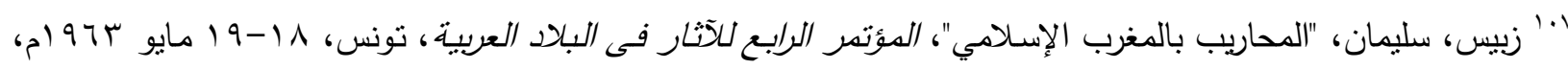


ووجدت محاريب ذات حنايا مضلعة، منلما في مساجد: عين البيضاء بمعسكر، الباي بعنابة، والجديد بالجزائر • وتضليع المحاريب بمساجد الغرب الإسـامي تأثنراً أندلسياً،"'، مستوحى من محراب جامع قرطبة ذو السبعة أضلاع'"' . وفي مساجد كل من ولايـة طرابلس وولايـة تونس اتخذت حنايا المحاريب هيئة نصف دائرية.

أمسا طاقيـة المحراب فقد تتوعت أثنكالها، ففي محاريب مسـاجد ولايـة الجزائر نجد أن أغلب طاقيات المحاريب اتخذت شكل ريع قبة. وتغطية المحاريب بربع أو نصف قبة من الممارسات المستخدمة بكثرة فى المساجد العثمانية بالغرب الإسلامي، وأقدم محراب باق غُطِّيَ بهذا الثكل هو محراب مسجد رباط المنستير،

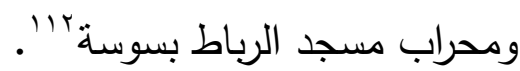

ومنها مـا اتخذ هيئة محاريـة، منثل: طاقيـة محراب الجامع الأخضـر، وطاقيـة محراب جامع سيدي الكتاني، وطاقية محراب جامع سيدي عقبة ببسكرة(')". وقد استخدم الثكل المحاري في الغرب الإسـامي في مناطق انتقال القباب في جامع القيروان والزبتونة، كما أنه ظهر كعنصر زخرفي في العمارة والفنون الأندلسية المغربيـة، كما في محراب جـامع القيروان، ومحراب جـامع المهديـة، وفي قبـاب جـامع قرطبـة ذات العقود المتقاطعة، وفي العصر المرابطي في قبة الباروديين بمراكش، وفي العصر الموحدى في باب الرواح، وفي

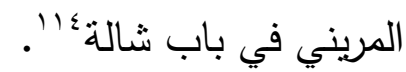

ومنها مـا اتخذ هيئة مضلعة، منلما فى طاقية محراب جامع عين البيضاء بمعسكر، وطاقية محراب

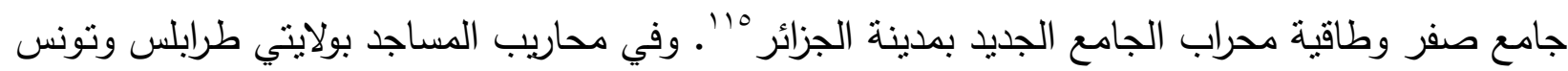
اتخذت طاقية المحراب شكل ربع قبة.

ويكتتف حنايا المحاريب عادة عمود أو أكثر من كل جانب. ففي مساجد ولاية الجزائر يكتتف معظم محاريبها عمدد واحد فى كل جهة، منلما فى مساجد مدينة الجزائر ، ومسجدي معسكر والباشـا بوهران. أو

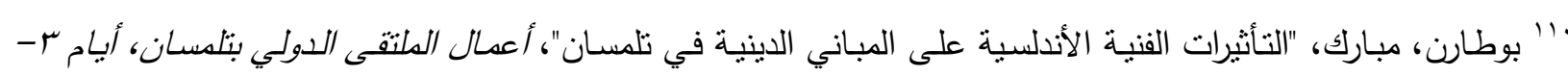

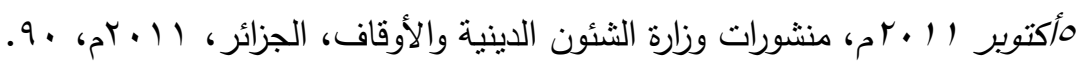

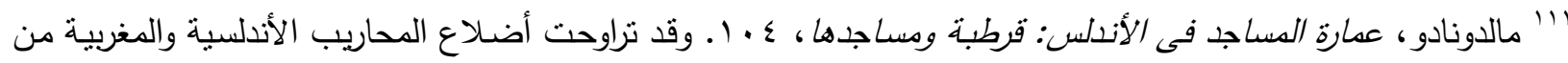

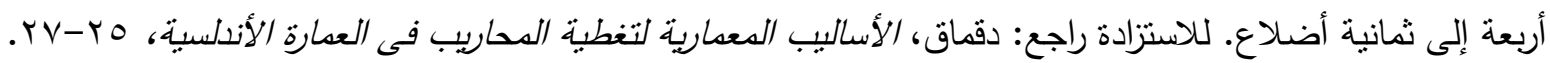

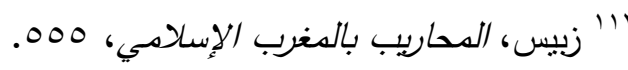

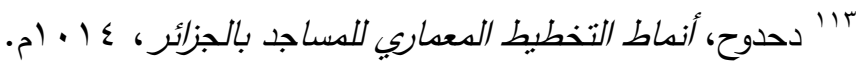

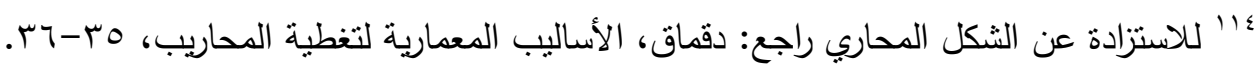
Balbás, Torres, L., La mezquita de Córdoba y las ruinas de Madinat Al-zahra, Editorial Plus-Ultra, 1952, 51-53; Marçais, G., L' Architecture Musulmane d' Occident, 16-17, 20, 44, 56- fig. 30, 109; Balbás, Torres, L., "La Mezquita Mayor de Qayrawān", Crónica Arqueológica de la España Musulmana II, 1981, 53-57; CAILlÉ, J., La ville de Rabat jusqu'au protectorat français. Histoire et archeology, Casablanca: Publications de l'Institut des Hautes-Études marocaines, t. XLIV, 2006, 139. 
يكتنف حنية المحراب عمودان من كل جهة، كما هو الحال فى محراب جامع سوق الغزل والجامع الأخضر وجامع سيدي الكتاني بقسنطينة (لوحة 7 (). في حين وجدت ثلاثة أعمدة تكتنف حنية المحراب من كل جانب فى محراب جامع سيدي عقبة ببسكرة. ومن الجدير بالذكر أن ظاهرة تعدد الأعمدة التى تكتف حنايا المحاريب لم تتنشر فى مساجد الجزائر إلا فى العصر العثماني، ولم تظهر من قبل سوى فى محراب مسجد سيدي أبي مروان بعنابة والذي برجع إلى العصر الحمادي. وكذللك الحال بالنسبة لتونس التى لم تعرف هذه الظاهرة ولم تتنتر بها حتى فى العصر العثماني "1". وفي مساجد ولاية طرابلس وولاية تونس يكتتف حنايا المحاريب عمود واحد من كل جهة، باستثناء محراب مسجد مصطفى قرجي فيكتفه عمودان من كل جهة. كما تتوعت أثكال عقود المحاريب، ففي ولاية الجزائر وجدت عقود محاريب نصف دائريـة، مثلما فى محراب جامع سيدي لخضـر، ومحراب جامع سيدي الكتاني. واستعمل العقد الحدوي فى محراب الجامع الجديد، ومحراب جامع عين البيضـاء بمعسكر • والعقد المـدبب المفصص ظهر فى محراب جامع صفر.

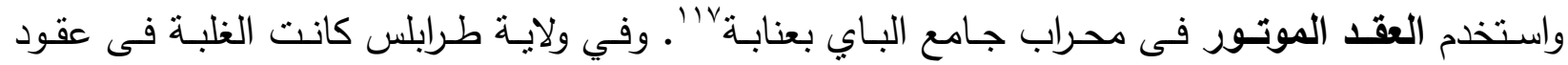
المحاريب للعقد النصف دائري، ومـع ذلك وجدت بعض المساجد التى حوت محاريبها عقود حدوة فرس كما هو الحال فى محاريب: جامع درنـة، جامع سيدي عبد السـلام الأسمر بزليطن، جامعي القرمـانلي وقرجي بطرابلس ^" . وفي مساجد ولاية تونس توجت حنايا محاريبها بعقود حدوة فرس دائرية.

:

ظهرت السقائف ثتقدم كثيرًا من واجهات المساجد فى العالم الإسـامي، واختلفت وظيفة وموضع وعدد هذه السقائف من مسجد إلى آخر ، فمن حيث الوظيفة: نجد أقدم نماذجها في مسجد بوفتاتة بمدينة سوسة 119

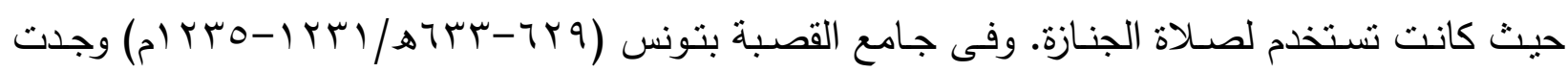

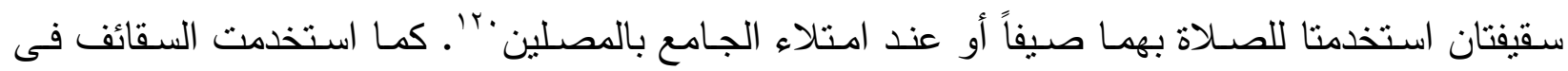
المسـاجد الريفية بمنطقة بني ورتـلان بشمال غرب الجزائر ؛ حيث كانت تقام بها الصلوات عند الضـرورة،

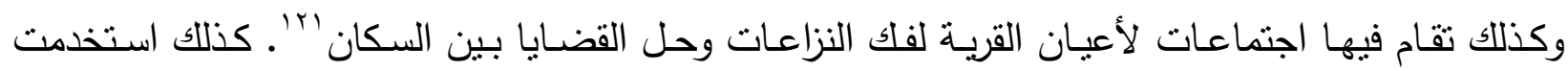

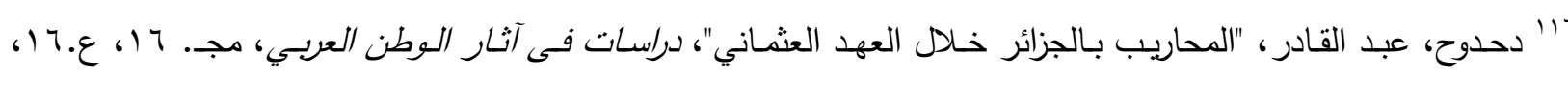

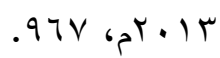

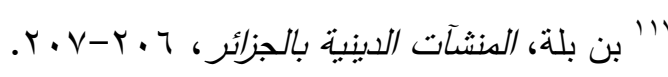

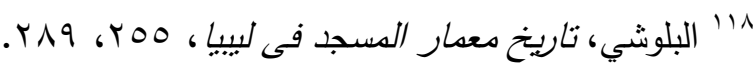
119 CReSWELL, K.A.C., A Short account of Early Muslim Architecture, Cairo: The American University in Cairo Press, 1989, 351.

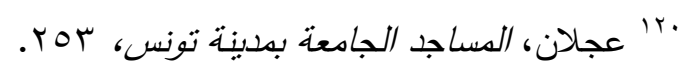

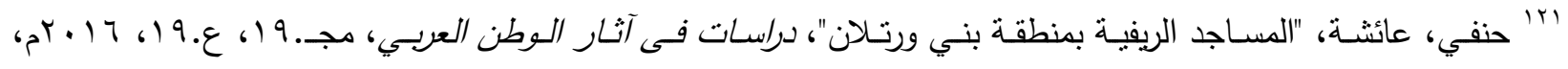


السقائف كعنصر اتصال وحركة لتسهيل حركة المرتفقين بالمسجد منلما فى مسجد الصالح طلائع بن رزيك

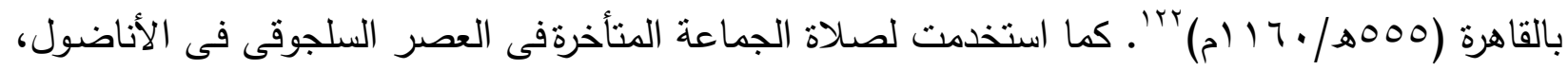
وكذلك فى فترة البكوات، وفى العصر العثمانى بr '. كذلك فقد ارتبطت وظيفة السقائف بالعوامل المناخية مثلما

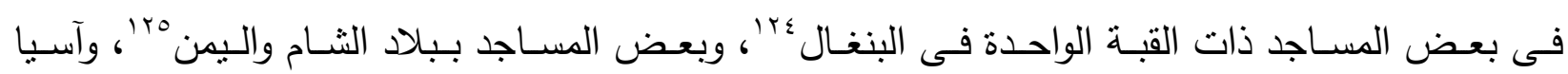

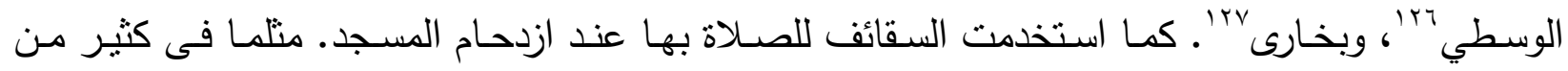

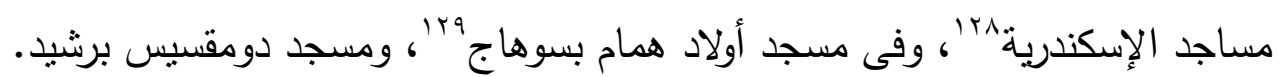

بار عثمان، محمد عبد الستار، موسوعة الععارة الفاطمية، الكتاب الأول: العمارة الفاطعية الحربية-الددنية- الدينية، القاهرة:

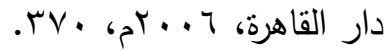

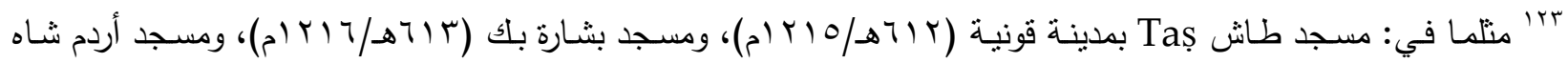

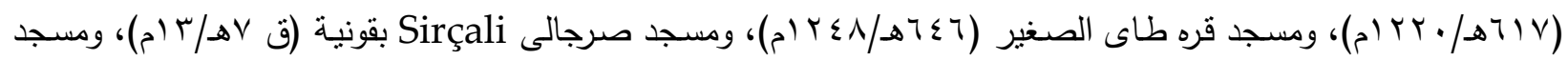

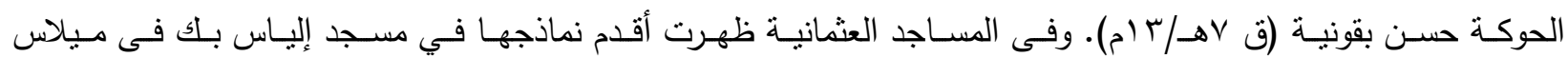

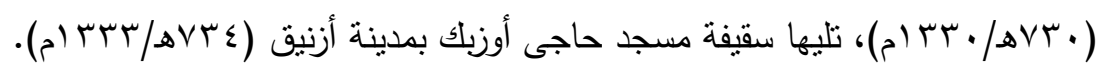

KUBAN, D \& o, Selçuklu Çağinda Anadolu Sanati, Istanbul, 2002, 152.

GodfreY, G., A History of Ottoman Architecture, London: Thames and Hudson Ltd, 1971, 17; SABIT K. , Türkiye'nin Üzerindeki Işik, Ankara: T.C. Kültur Bakanliği, 2002, 233

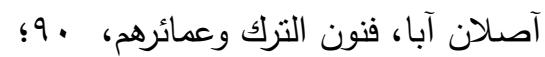

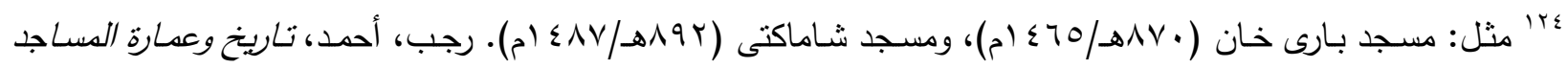

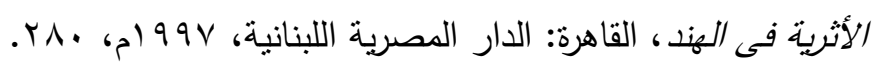

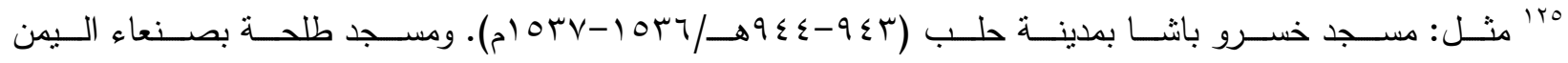

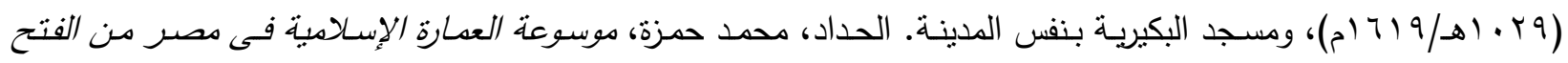

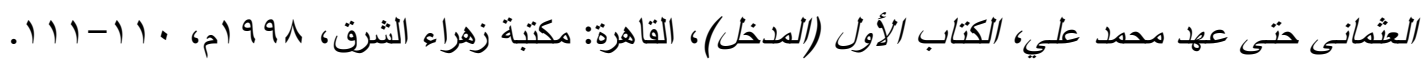

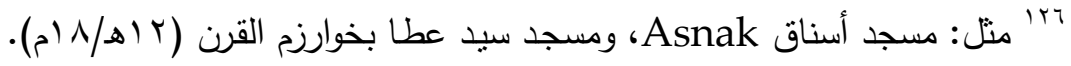

O'KANE, B:.« Studies in Persian Art and Architecture , Cairo: The American University in Cairo Press, 1995, 342; PROCHAZKA, A. B., Architecture of The Islamic Culture« KHAWĀRIZM», OICC \& MARP, 1991, 52.

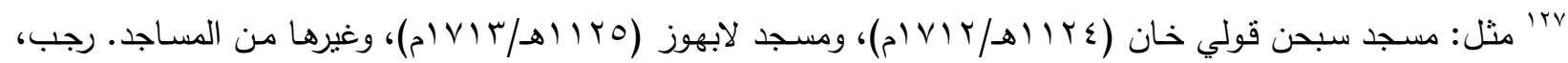

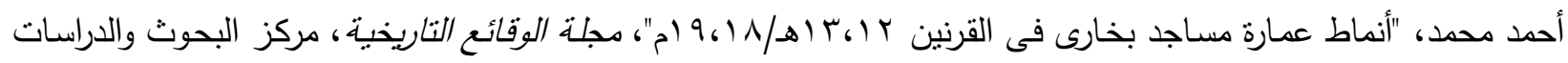

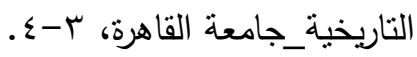

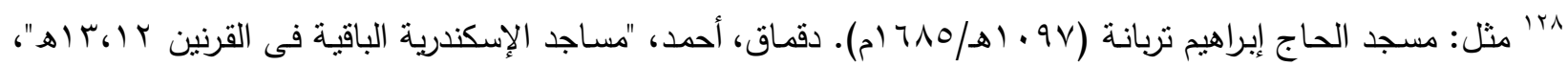

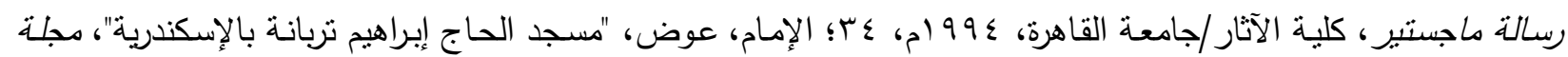

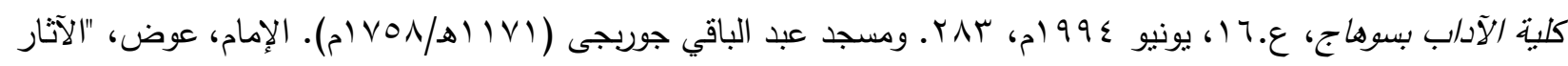

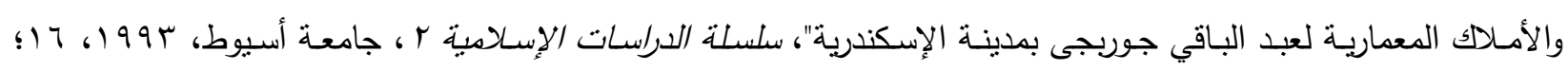

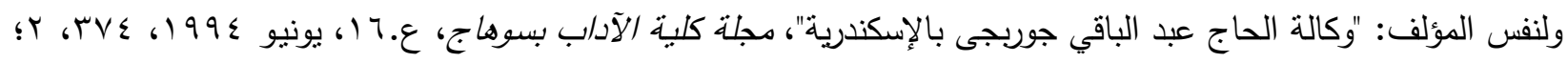

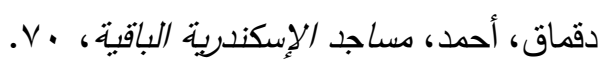


ومسن حيث الموضـع: فقد اختلف موضـع السقيفة بالنسبة للمسجد بـاختلاف تخطيط وحدود المسجد والمباني والثـوارع المجاورة لـه، حيث يتقدم بعض هذه المساجد سقيفة من اتجاه واحد، وبعضـها تحيط بـه السقائف من اتجاهين، والبعض الآخر تحيط به السقائف من ثلاث جهات. ومن حيث المساحة: فقد اختلفت مساحات السقائف من مسجد لآخر وفقاً لوظيفتها ولمساحة المسجد. ومن حيث التغطية: فتغطيها إما قباب أو أقبية أو كليهما، أو أسقف خشبية مسطحة أو مائلة ·r'.

وقد ظهر عنصر السقيفة فى مساجد العصر العثماني محل الدراسة، ففى ولاية الجزائر وجدت السقيفة فى جامع الباي بعنابة تتقدم بيت الصلاة من الناحية الثمالية' 'ا . وفى ولاية طرابلس بحيط ببيت الصلاة فى جامع أحمد باشا القرمانلي سقيفة من ثلاثة اتجاهات، أما جامع مصطفى قرجي فنتقدم بيت صدلاته سقيفة من اتجاهين الثمالي والثرقي بrا'. كما تقدمت السقائف أيضـاً مساجد: درغوت باشا، وابن مقيل، وشائب العين، وخليل باشنا، وعثمان بوقلاز، والجامع العتيق بينى غازي بّ'. وفى تونس احتوت بعض المساجد على سقيفة تتقدم بيت الصلاة، وكانت من اتجاه واحد فى جامع يوسف داي، ومن ثلاثة اتجاهات فى جامع حمودة باشا، وجامع يوسف صاحب الطابع، وجامع سيدي محرز گَّا.

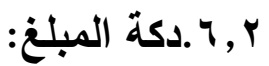

اشثترط الفقهاء لصحة صلاة الجماعة ضرورة رؤية المأموم للإمام أو مشاهدة بعض صفوف المصلين، أو أن يتم ذلك بسماع صوت الإمام أو صوت المبلغ عنه. وكان هذا الحكم سبباً في ظهور دكة المبلغ كأحد عناصر الانتفاع بالمسجد، وصارت من قطع أثاثهُّا'. ولم تكن مساجد الغرب الإسـلامي تحتوي على دكة للمبلغ، إذ جرت العادة أنه يوجد فى الجامع الواحد أربعة مؤذنين، أحدهم يقف خلف الإمـام، والثانى حيث ينتهي إليه صوت الأول، والثالث حيث ينتهي صوت الثانى، ثم الرابع كذلك على هذا الترتيب بَ'. وذكر

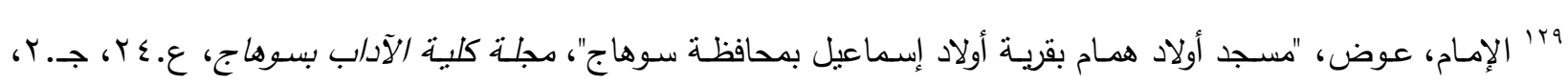

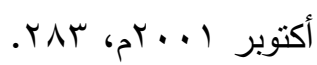

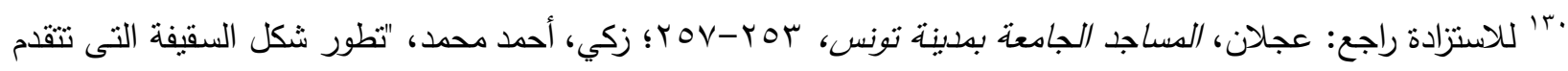

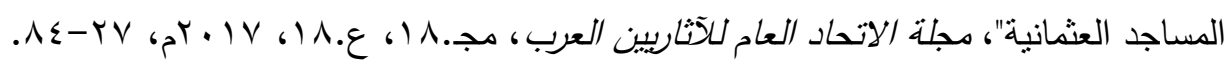

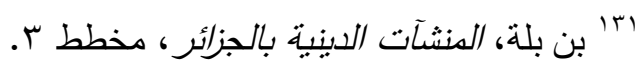

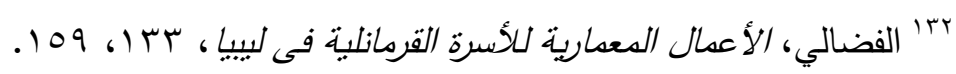

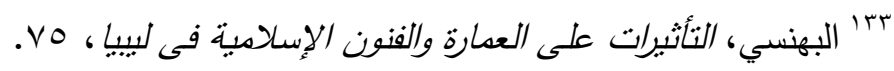

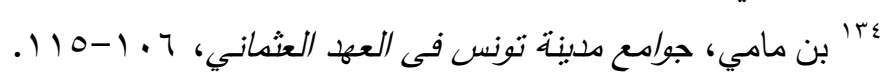

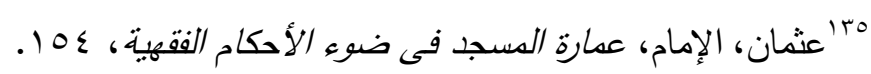

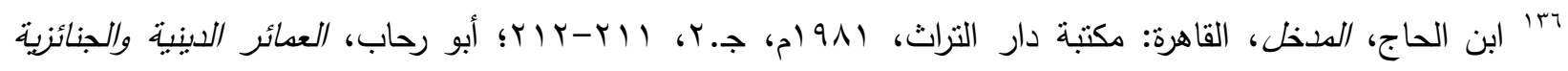

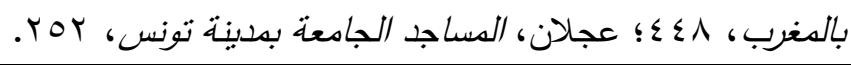


المراكثي أثناء حديثه عن الموحدين: "فأما صفة أحوالهم وخطبتهم فى جُمعهم، ...إذا جلس الخطيب فوق

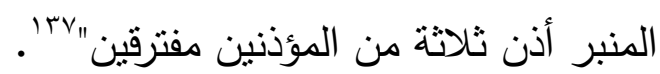

ولم تعرف مساجد الغرب الإسلامي بشكل عام دكة المبلغ إلا في العصر العثماني ^ّ، ولعل السبب

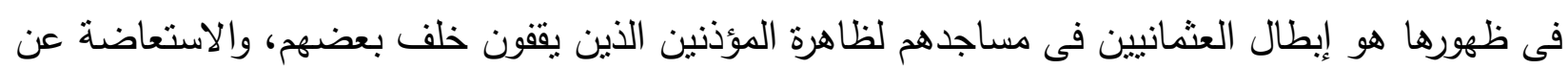

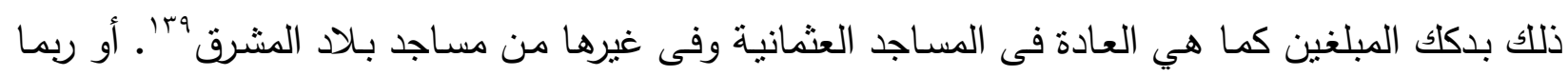

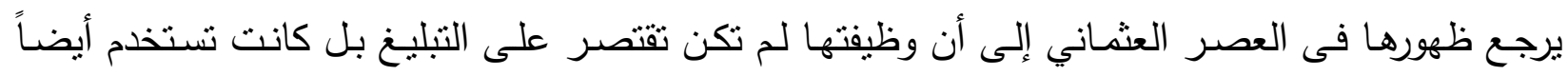

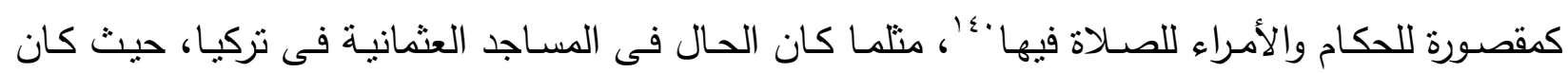

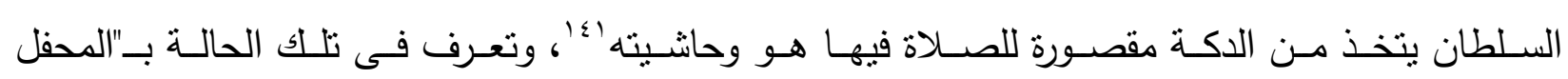

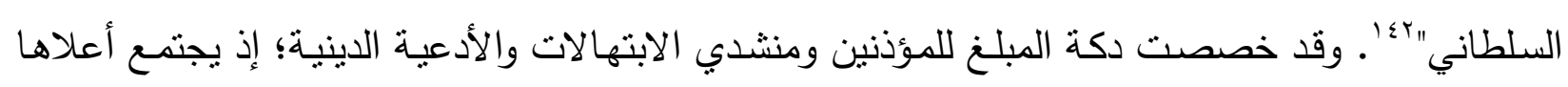

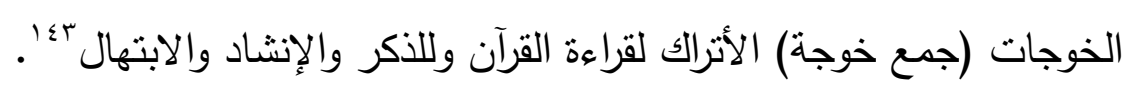

ففي ولاية الجزائر لا تزال بعض المساجد تحتفظ بدكة المبلغ، وقد صنعت دكلك المبلغين فى الجزائر

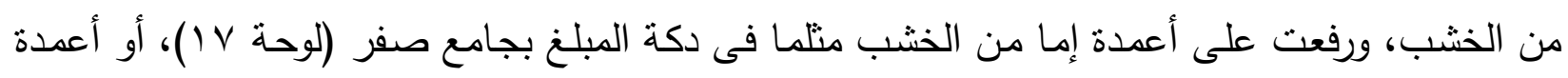

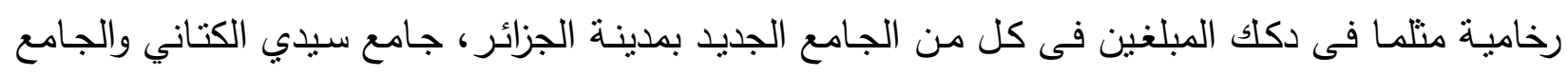

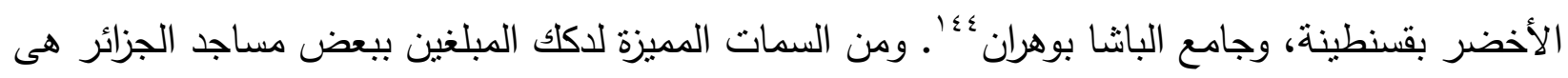

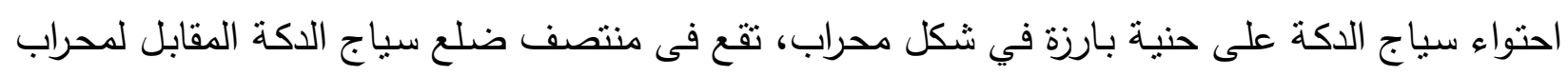

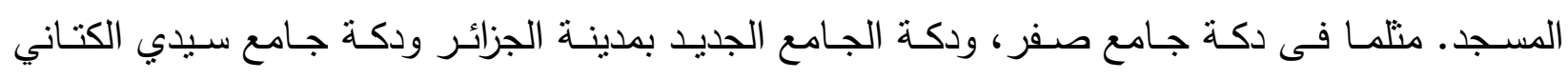
بقسنطينة ؛ 1 .

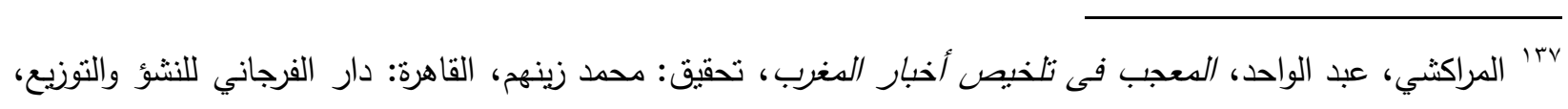

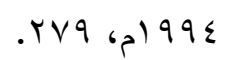

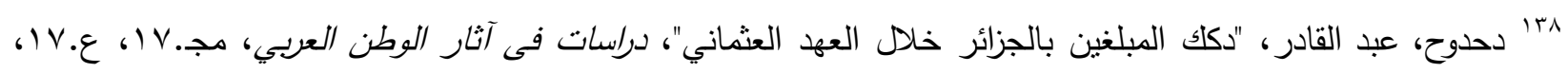
(

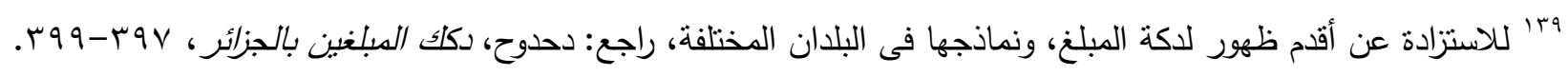

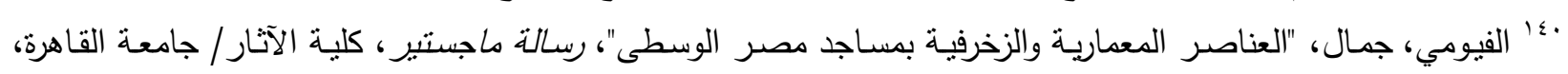
促 اء' السباعي، أميرة، "الجامع المدرسة فى استانبول خلال النصف الثاني من القرن العاثر الهجري"، رسالة ماجستير، كلية

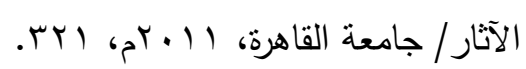

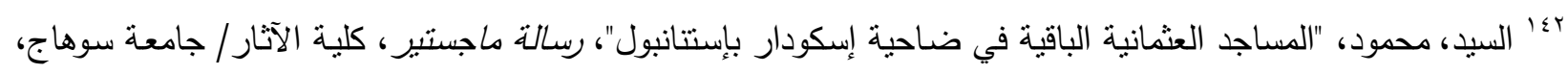
. 2996 م

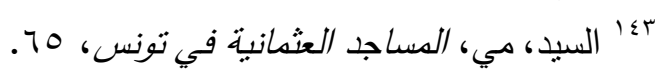

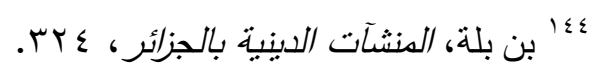

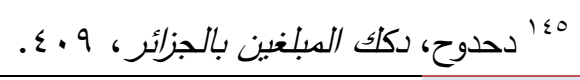


وفى ولاية طرابلس صنعت دكك المبلغين بالمساجد العثمانية من الخشب وحُملت على أعمدة خشبية، مثلما فى دكة المبلغين بجامع أحمد باشـا القرمانلي، ونظيرتها بجامع مصطفى قرجي بءا، ووجدت أيضاً فى بـ

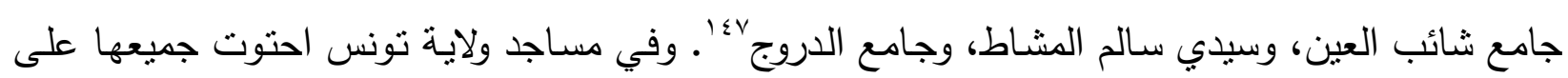

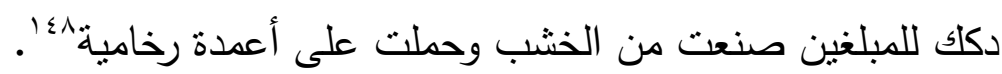
وعن موضـع دكة المبلـغ نلاحظ أنها تقع عـادة فى نهايـة بيت الصـلاة مقابلة للمحراب، الأمر الذى يمكن المبلغين من رؤية الإمام وفى الوقت ذاته يصل صوتهم إلى جميع المصلين بالمسجد سواء داخل بيت الصلاة أو خارجه.

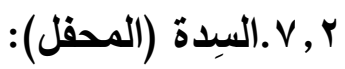

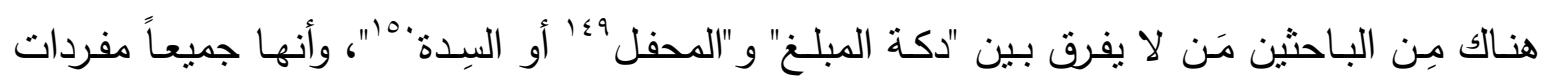
لعنصر معمارى واحد وهو دكة المبلغ، وأن كل اسم منها اشتهر بمنطقة أو إقليم من الأقاليم الإسلامية، حيث

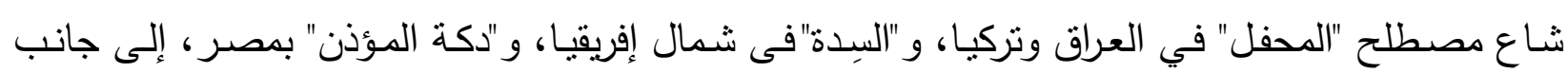

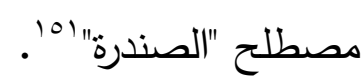

وفي الواقع فإن مصطلح "المحفل" في المشرق بوازي مصطلح "السدة" فى بـلاد المغرب، وهو بذللك مختلف من حيث المساحة والوظيفة عن "دكة المبلغ"؛ فالسِدة: بكسر السين، هى سقف خشبي معلق محاط ب"درابزين"، يتم من خلاله تقسيم أية مساحة إلى جزعين: علوي وسفلى، وبذلك يضاعف المساحة المستخدمة، ويتم الصـود إليها عن طريـق سـلم خثبي أو أكثر، وقد استخدمت السـدة فى كثير مـن العمـائر الدينيـة

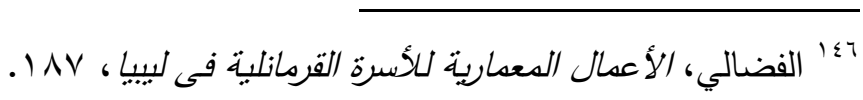

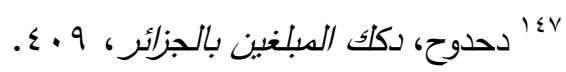

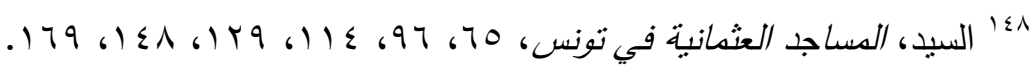

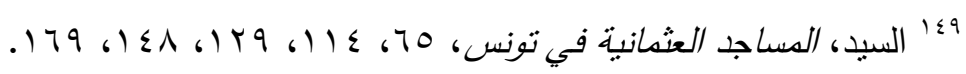

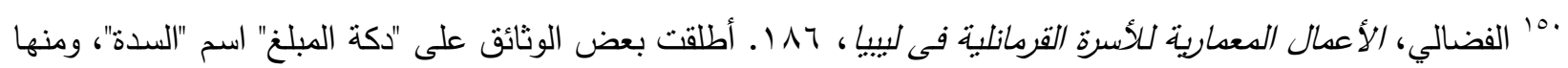

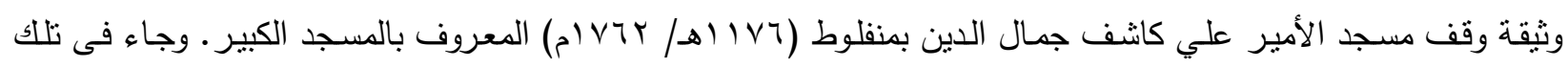
الوثيقة: "...يتوصل من الباب الدذكور إلى محل العبادة المشتمل على منبر للخطيب ومحراب به عمودين من الحجر الرخام الأبيض، وعلى كرسي معد للجلوس عليه لقراءة القرآن والحديث النبوي، وعلى سدة للمؤذنين". بدر ، حمزة عبد العزيز ، "الآثار

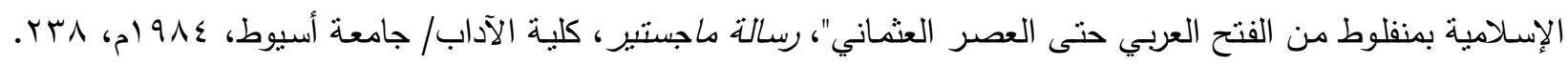

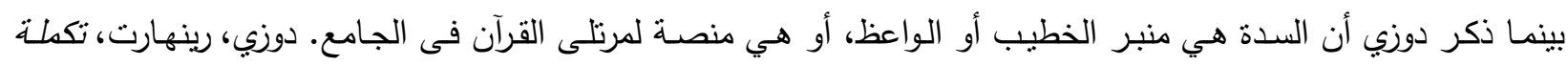

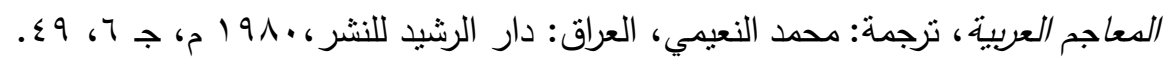

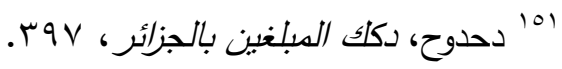


والمدنية_or! ففي الجوامع تشغل السدة بلاطة أو أكثر من البلاطات الخلفية أو الجانبية أو كليهما معاً من

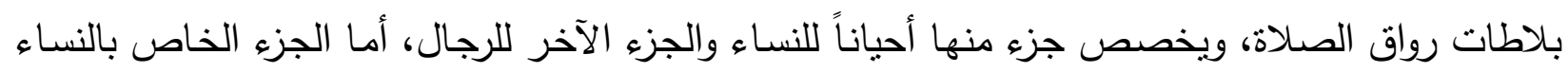

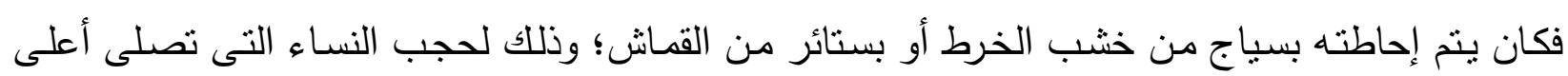

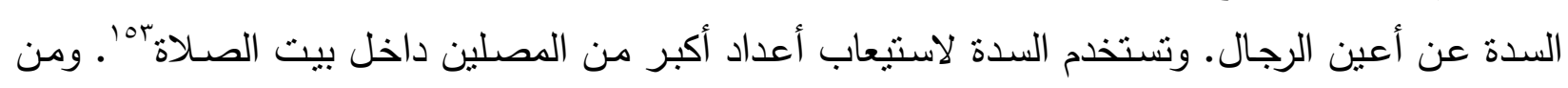

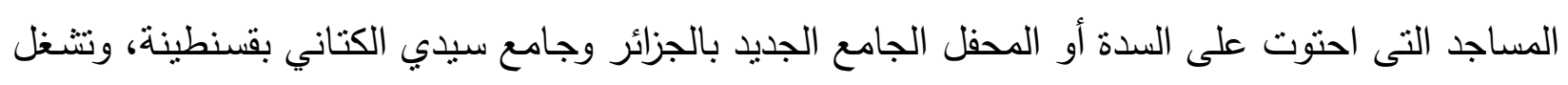

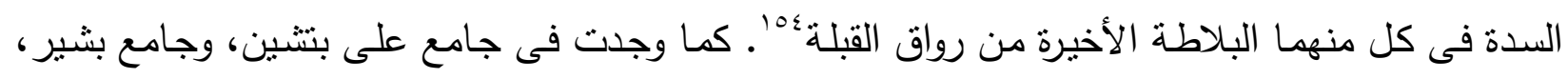

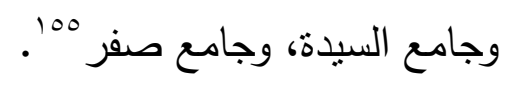

وفى تونس وجدت السدة في الجامع الجديد 104 ، وفى جامع سيدي محرز "ov ، وجامع حمودة بانشا،

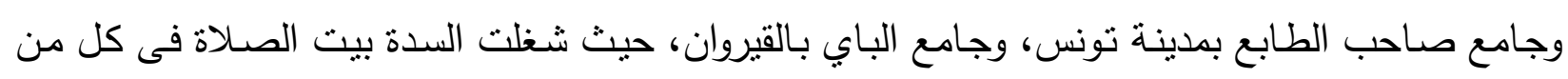

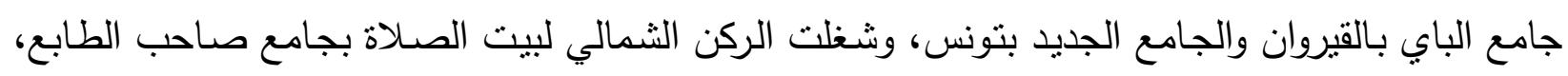

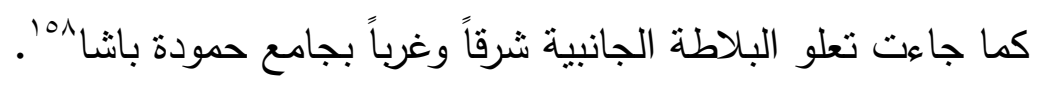

وفي ليبيا ظهرت السدة فى أواخر العصر العثماني الأول، وأقدم أمتلتها ظهرت فى جامع محمد باثنا

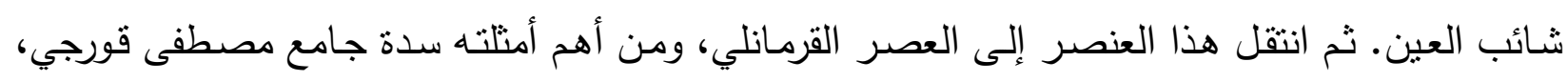

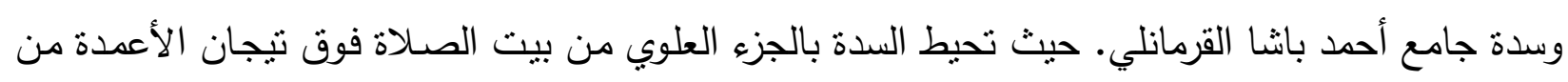

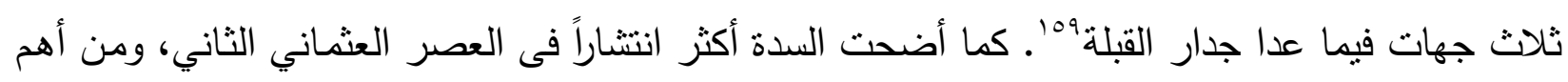

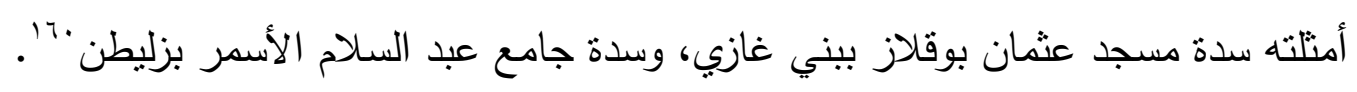

101 استخدمت السدة أيضاً فى الدور ، خاصـة ذات المساحات الضيقة، كذلك استخدمت فى الحوانيت لتزيد من المساحة

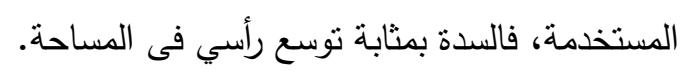

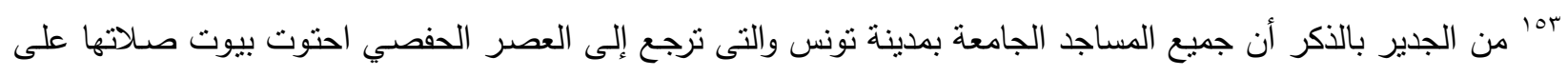

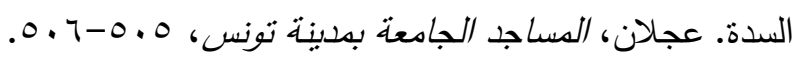

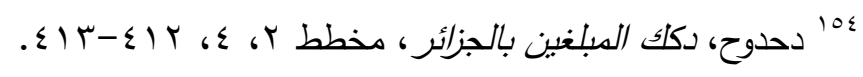
100 100

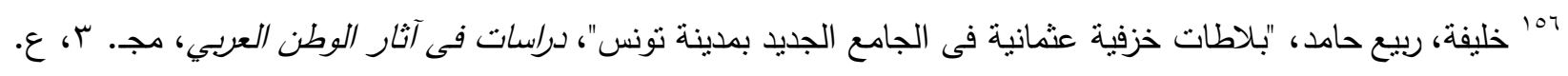

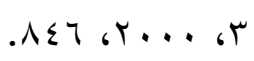

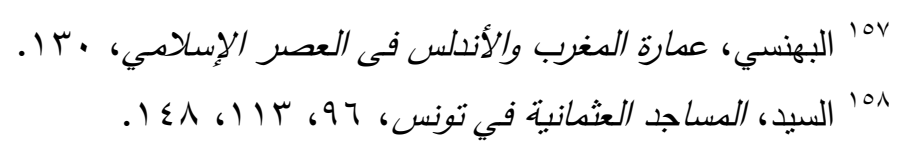
109

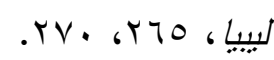

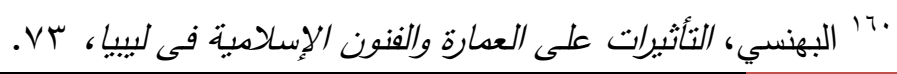


نص القرآن الكريم والسنة النبوية على ضرورة طهارة المسلمين وتوضئهم قبل الصلاة؛ ولذلك بنيت الميضآت مجاورة للمساجد أو ضمن تكوينها المعماري، وصارت من عناصر الانتفاع الضرورية بها. وتتكون

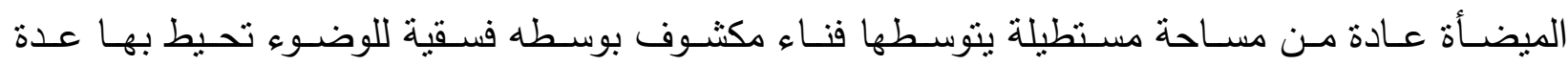
مراحيض "'ا". ولقد كان الحرص على طهارة المساجد وتجنيبه ما لعله ينبعث من روائح غير مرغوب فيها أثره

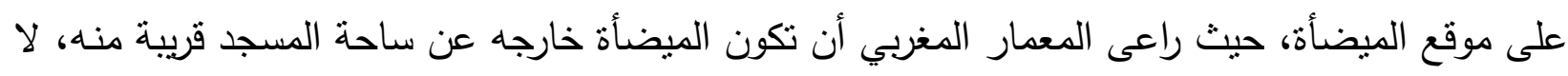

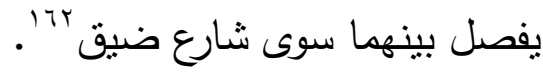

وقد كان للشروط الفقهية الخاصة بالوضوء وطهارة الماء أثرها على تخطبط وشكل الميضأة"كا". فنجد

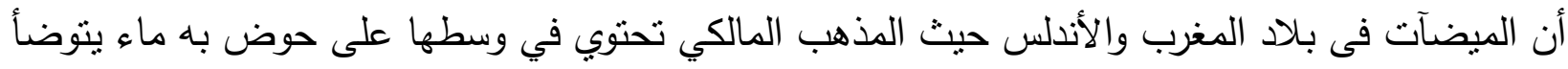

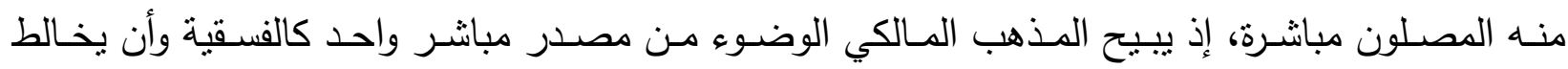

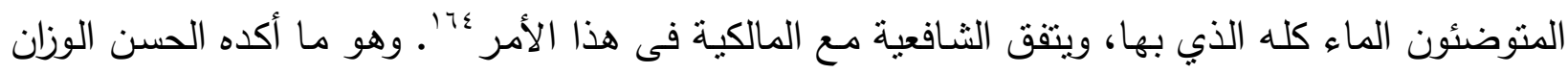

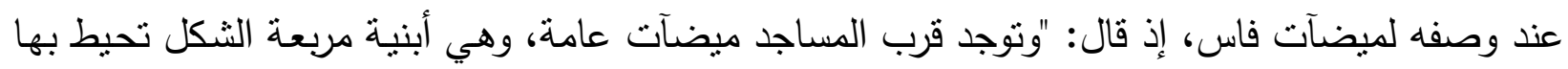

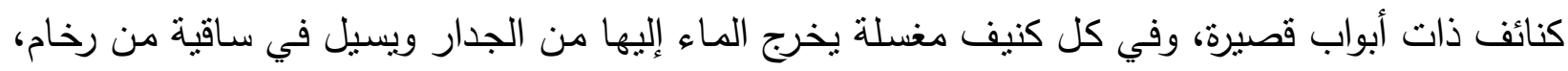

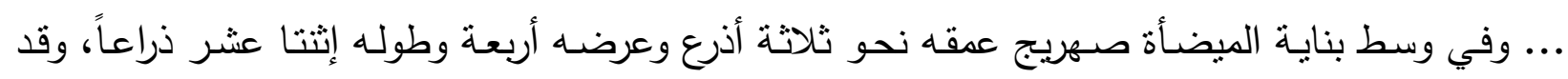

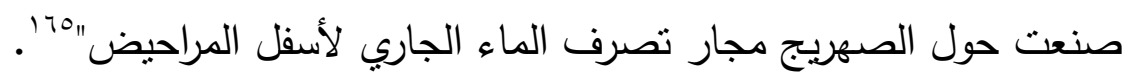

ومع قدوم العثمانيين تغير شكل الميضآت حيث المذهب الحنفي الذي رأى أصحابه أنه لا يجوز أن

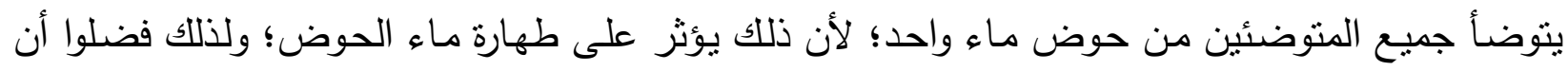

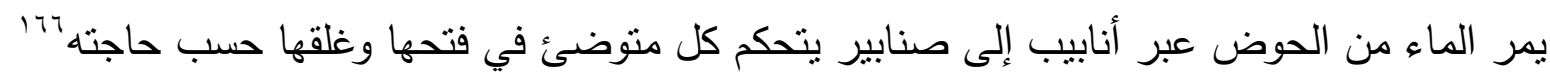
ومسن خـلال دراسـة عدد من الميضـآت الملحقة ببعض المسـاجد ببلاد المغرب الأدنى نلاحظ أنها

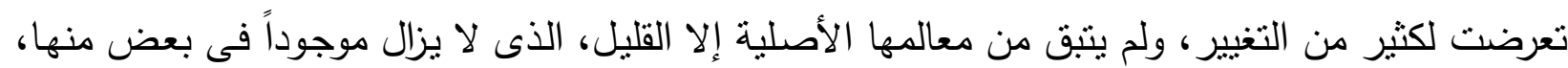

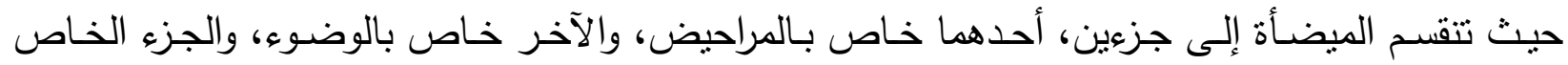
بالوضوء عبارة عن حوض من الحجر تخرج منه بزابيز من النحاس، وتتقدم الحوض مصطبة حجرية يجلس لتصل

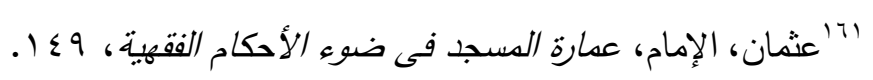

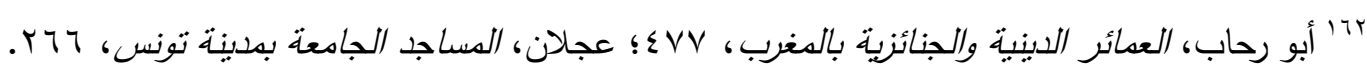

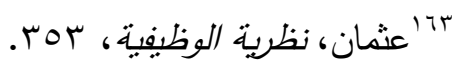

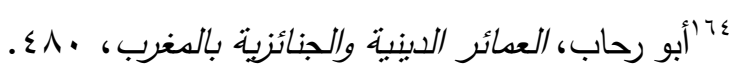

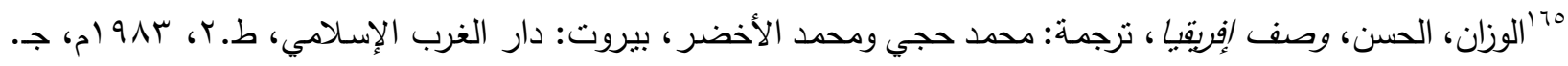

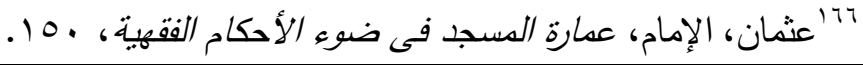


عليها المتوضئ، ويفصل بين الحوض والمصطبة قناة لتصريف المياه المستخدمة فى الوضوء، وقد تميزت

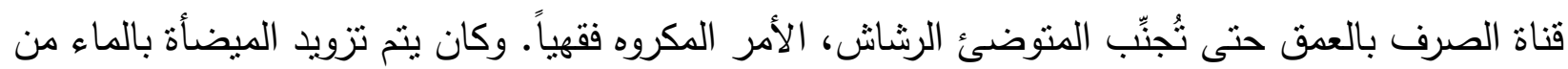

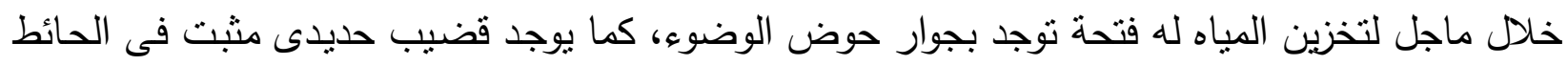

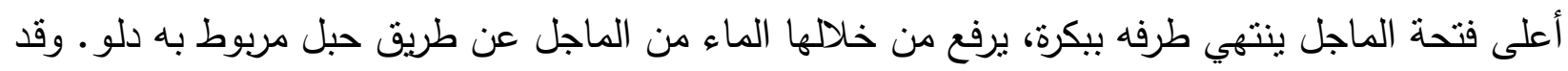

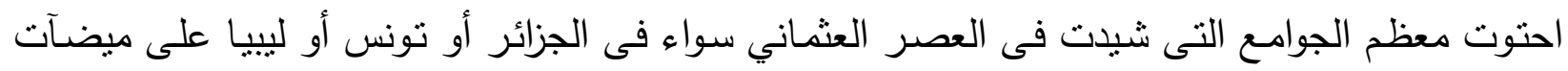

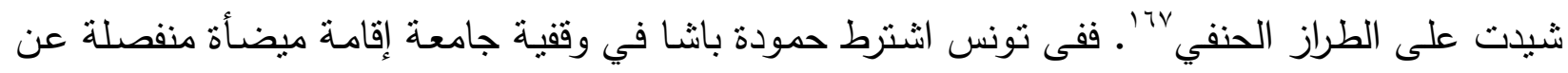

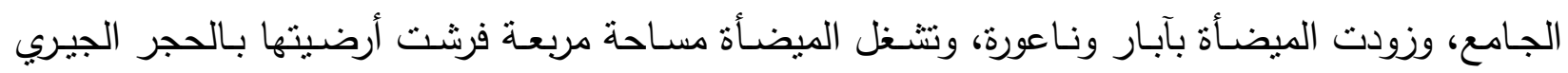

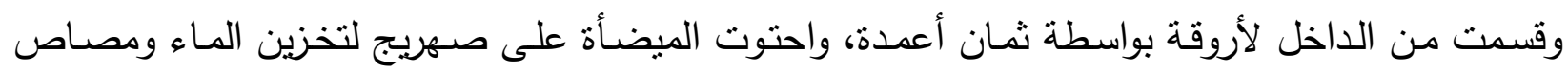

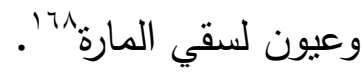

r 9 ـ الأعمدة والدعامات:

عُرفت الأعمدة بعدة مسميات: فهو عمود في المشـرق، وسـارية فى المغرب، وشـمعة فى لبنـان،

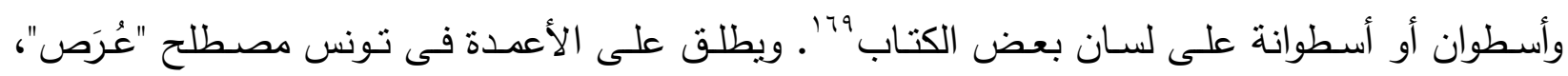

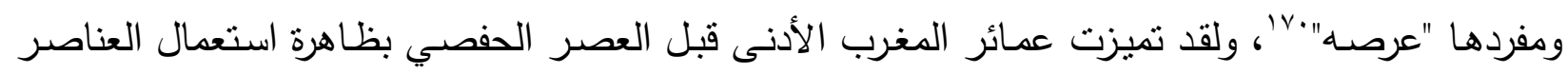
المعمارية الموجودة فى المواقع الرومانية والبيزنطية كالأعدة والتيجان والكوابيل، فلم يكن أي أثنر يخلو منها

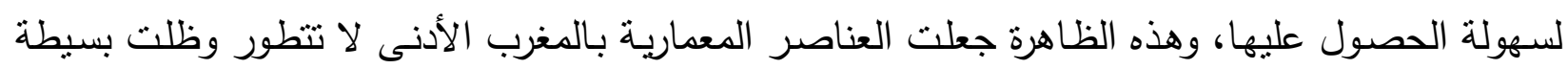

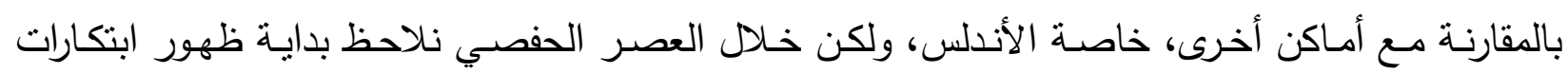

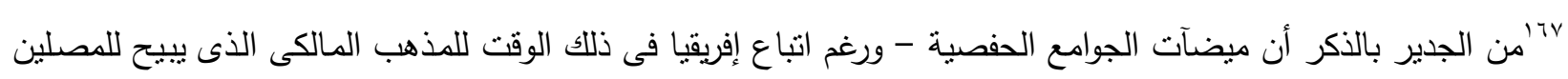
أن يتوضأوا من حوض واحد- يتم الوضوء منها عن طريق صنابير يتحكم المتوضئ فى فتحها وغلقها، وهو ما اتبع أيضاً فى انى

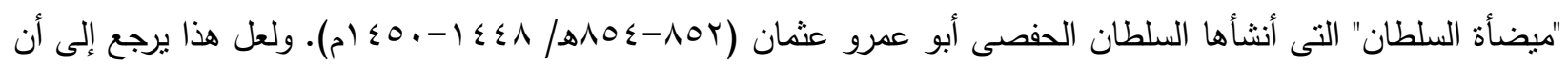

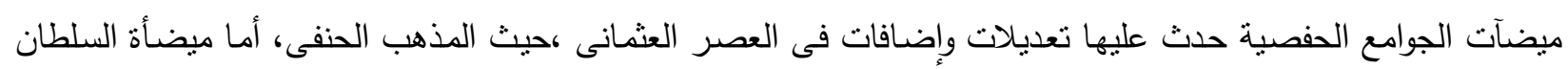

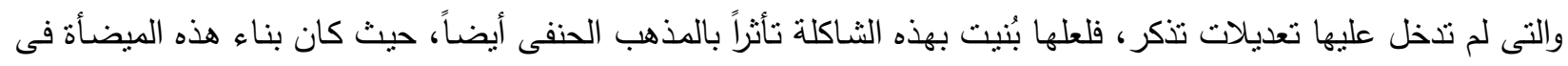

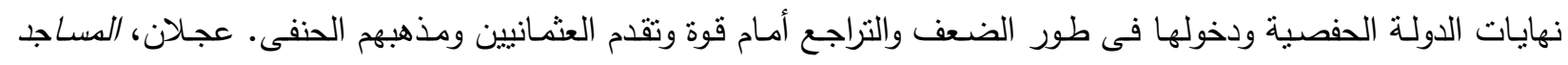

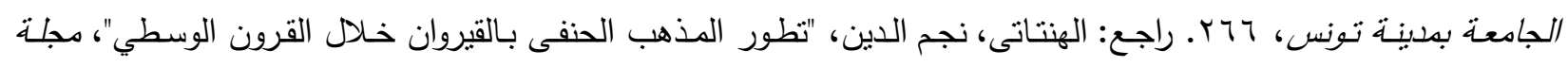

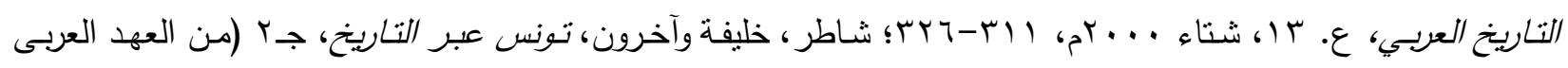

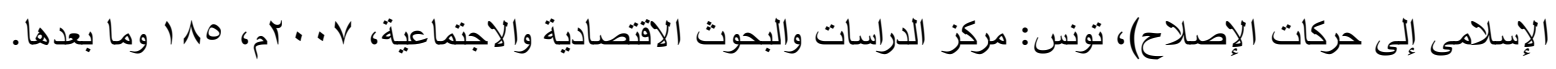

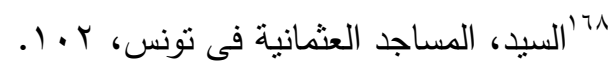

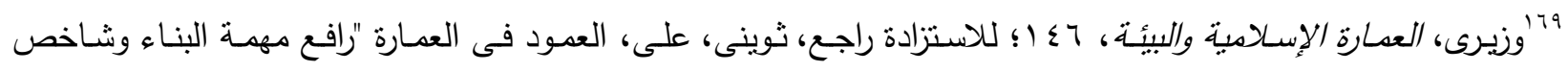
available on line at الحكمة في حيثياته" http: //www.skfupm.com/vb/showthread.php?t=9964 Accessed 15/05/2009 .

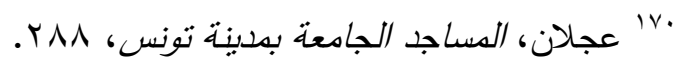


محلية، تتمثل فى نحت عناصر معمارية زخرفية متطورة أو متأثرة بأساليب فنية مشرقية ومغربية-أندلسية 'ال، الأمر الذي تطور بشكل أكبر فى العصر العثماني. لنئ. ونلاحظ ندرة استخدام الدعامات فى المساجد مقارنة بالأعمدة، ونجد أقدم ظهور للدعامات فى بـلاد

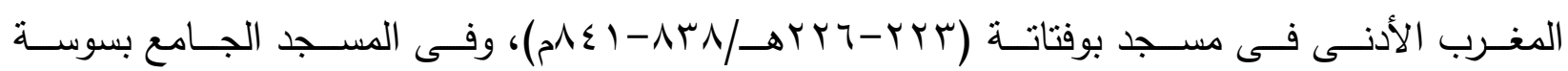

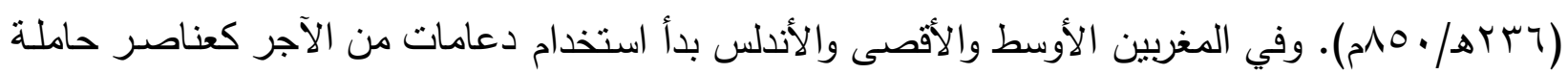

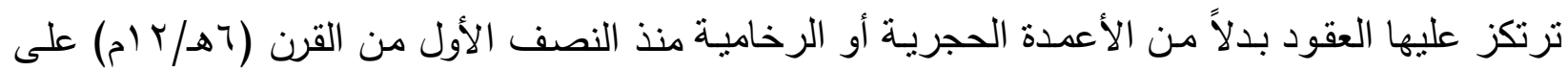
أيدي المرابطين

وللأعمدة والدعامات فى المسجد وظائف أخرى بجانب وظيفتها الإنثـائية منها: أن ابتدارها والصـلاة

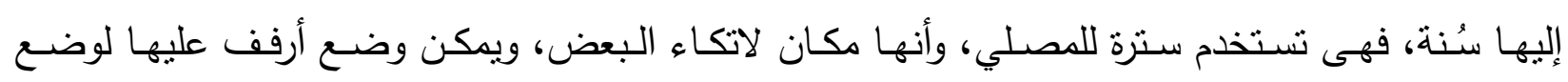

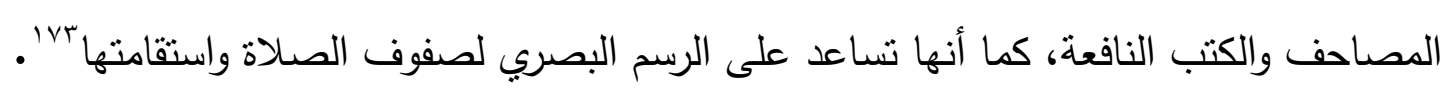
وتباين استخدام الأعمدة والاعامات فى حمل الأسقف بمساجد المغربين الأدنى والأوسط فى العصر العثــي، فبعض المسـاجد استخدم بها الأعمدة فقط، وبعضهـا استعمل بـه الدعامات، وبعضـها جمـع بين الأعمدة والدعامات، وبعضهها خلا من كليهـا. ففي ولاية الجزائر نجد أن المساجد التى بُنيت على الطراز

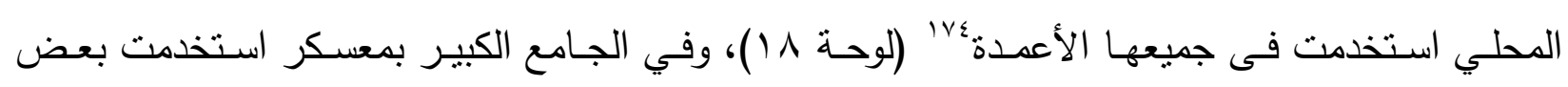
الدعامات بجانب الأعمدة (لوحة 9 ( ). أما المساجد التى تتبع الطراز العثماني فمنها ما احتوى على الأعمدة متلما فى جامع عين البيضاء بمعسكر ، جامع صفر ، جامع كتشاوة، وجامع القصبة الداخلي بمدينة الجزائر • وبعضها ارتكزت أسقفه على مأى الدعامات كجامع علي بتشين والجامع الجديد بالجزائر العاصمة. وبعضها جمع بين الأعمدة والدعامات مثل: جامع الباي بعنابة وجامع الباشا بوهران. وهنا نلاحظ تأثير التخطيط ونوع التغطية على استخدام الأعمدة من عدمه؛ فالمساجد ذات التخطيط المحلي الطـراز والمغطـاة بأسقق مسـطحة أو أقبيـة تحتوي على أعمدة، أمسا اسـتخدام الـدعامات فـارتبط

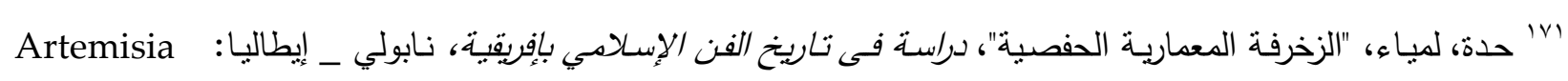
$.11 \mathrm{~V}, \mathrm{P}, \ldots$. E Comunicazione

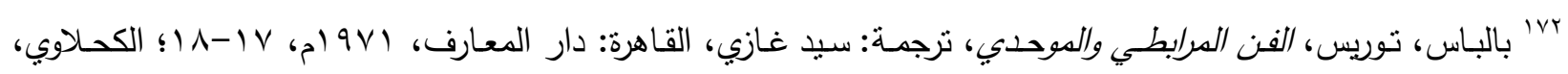

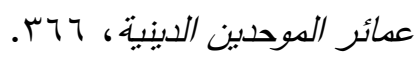

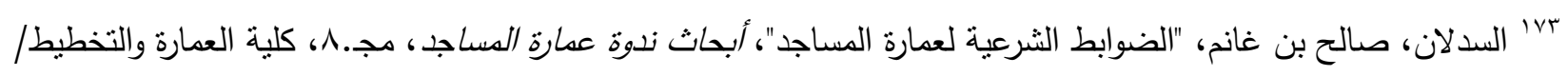

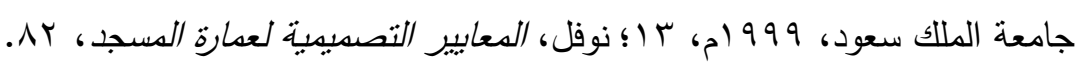

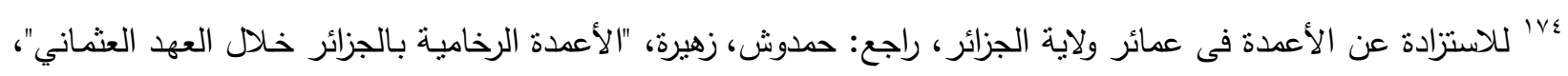

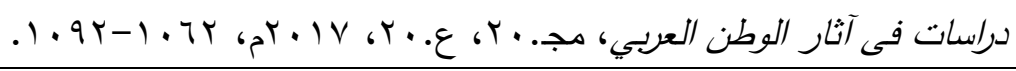


بالمساجد ذات التخطيط العثماني والتى تحتوي على قباب مركزية كبيرة، حيث إن ضخامة هذه القباب وتقلها يتطلب وجود دعامات كبيرة ترتكز عليها لتتحمل نقل القباب.

وفى ولاية طرابلس استخدمت الأعمدة والدعامات فى حمل الأسقف، ولكن كانت الغلبة للأعمدة التى

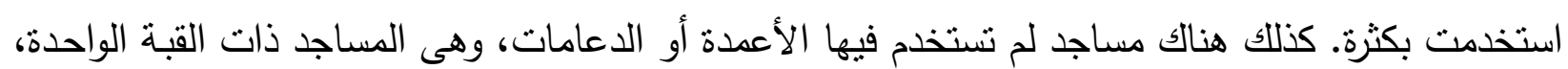

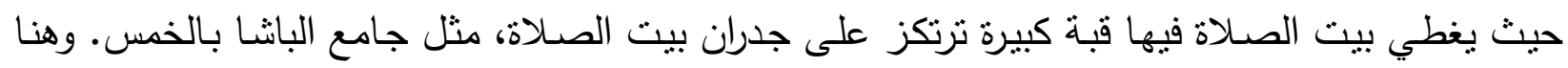
تبرز مرة أخرى علاقة التخطيط ونوع التغطية باستخدام الأعمدة أو الدعامات. وفي ولاية تونس استخدمت الأعمدة فى حمل الأسقق فى جميع المساجد التى على الطراز المحلي،

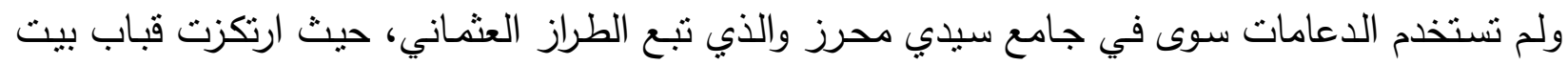

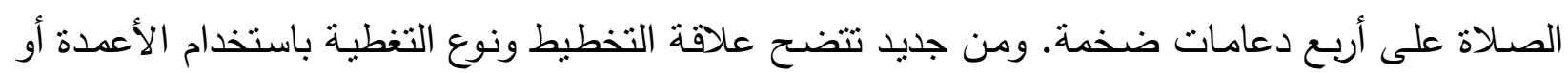

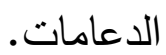

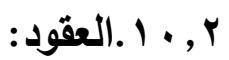

تتوعت أثنكال العقود المستخدمة فى البائكات لحمل الأسقف، ولكن كانت الغلبة لعقد حدوة الفرس والعقد النصف مستدير • والعقد الذى على هيئة حدوة فرس يعرف بأكثر من اسم، كالعقد الحدوي أو المتجاوز

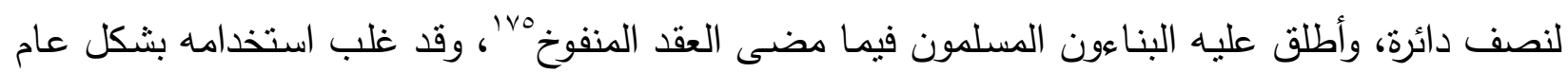

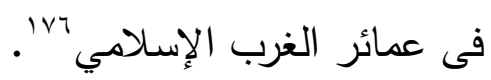

ولعل الدافع لثنيوع هذا النوع من العقود فى عمائر الغرب الإسلامي تلك المميزات التى يتمتع بها، كقوة

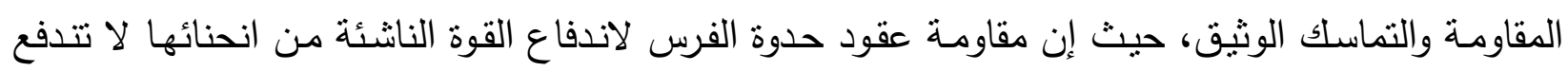

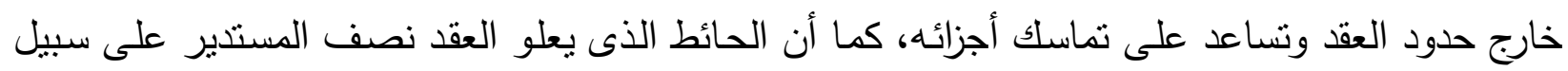

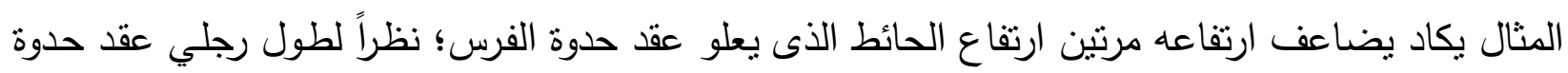

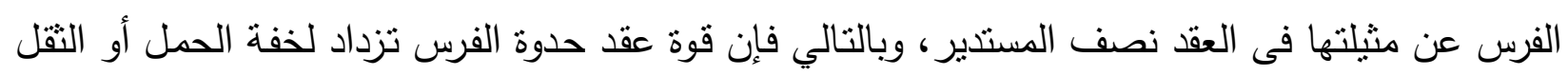

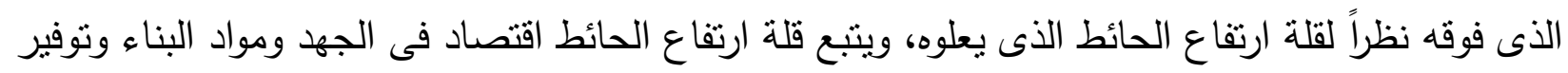

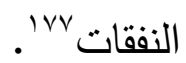

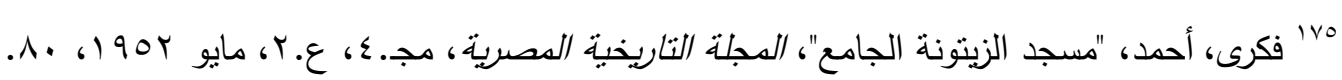

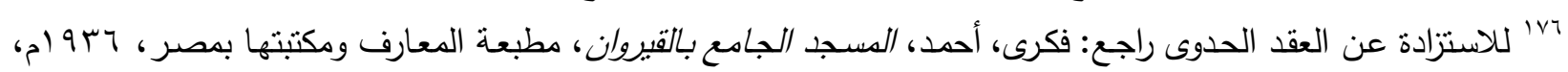

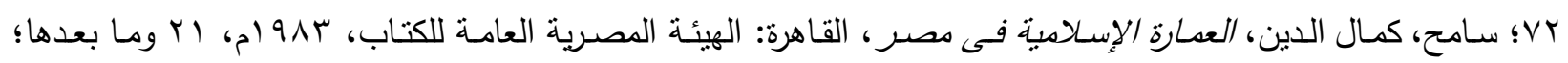

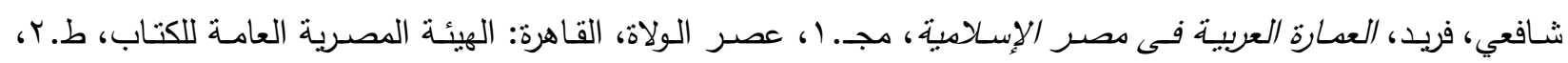

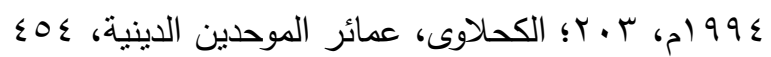
JoHnston, H. H., The origin of the Horse-Shoe Arch, Man, Vol. 14, 1914, 36

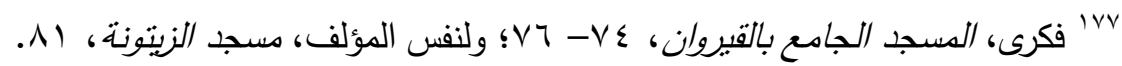


ولجـأ المعدـار إلى استخدام عقد حدوة الفرس لحمل الأسقف ببائكات الجوامـع نظراً لقصر الأعمدة عـادة، وظـاهرة قصـر الأعمدة تميزت بها عمـائر شـمال إفريقيا والأندلس 'VA، حيث يبدأ خصـر العقد بعد الدعامـة مباشـرة ويطول فـلا تبدأ العقود إلا بعد ارتفـاع مترين الخاصسية لا تتوافر إلا في عقد حدوة الفرس، بالإضـافة إلى أن ارتفـاع عقد حدوة الفرس ليس محدوداً

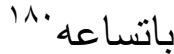

أما العقد النصف مستدير فعلى الرغم من انتناره وشيوعه فى مختلف بلدان العالم، فإنه يصعب تحديد أول نموذج له أو تحديد العصر الذى ظهر فيه، أما أقدم مثال باق له من العمارة الإسلامية فيتمنل فى عقود

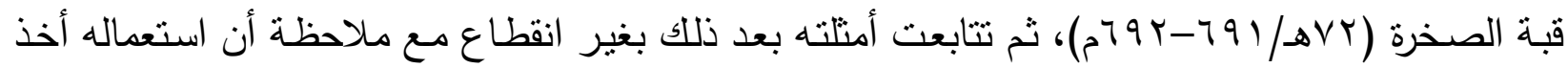
يقل تدريجياً مع ازدياد الإقبال على الأنواع الأخرى التى انتشرت فى العمارة الإسلامية فى الثرق والغرب''. أما العقود المفصصة فقد ظهرت فى المغرب الأدنى منذ العصر الأغلبي فى الجامع الكبير بالقيروان זي'. والعقود عادة ما ثُبنى على شََّّات خشبية (فورمات أو عبوات) وتتكون هذه الثدَّات من القطع الخشبية التى يسمر بعضها إلى بعض بحيث يشكل سطحها الخارجي انحناء العقدَ'1. ويحتاج بناء العقد إلى أربع خطوات، تبدأ بتجهيز "الفورمـة" وتركيبها فى المكان المطلوب، ثم البناء فوق الفورمـة، ثم فك الفورمـة، ثم

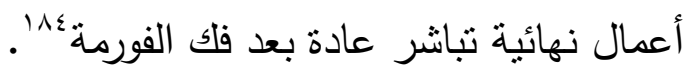

ففي مسـاجد ولايـة الجزائر اسـتخدم العقـــ التصـف دائسري فـى جامع صـفر، والجـامع الجديد بمدينـة الجزائر ، وجامع سيدي لخضر وجامع سيدي الكتاني بقسنطينة، وجامع الباي بعنابـة. كما استخدمت عقود حدوة الفرس فى جوامع: القصبة الخارجي بمدينة الجزائر (لوحة ^ ( )، الباشا بوهران، وعين البيضاء والكبير بمعسكر (لوحة 9 (). وظهر العقد المدبب في جامع سوق الغزل بقسنطينة. كما استخدم فى جامع الباي بعنابة عقود من النوع الإهليجي 110.

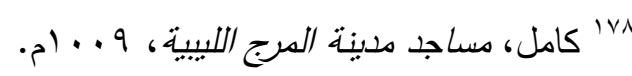

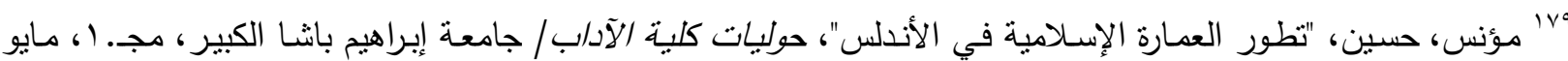
rIV 6 1901

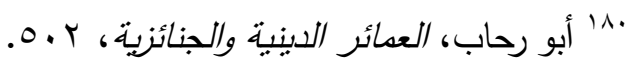

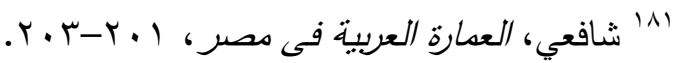
182 MARÇAIS, L' Architecture Musulmane d' Occident, 44.

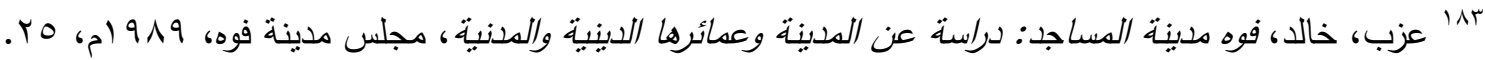

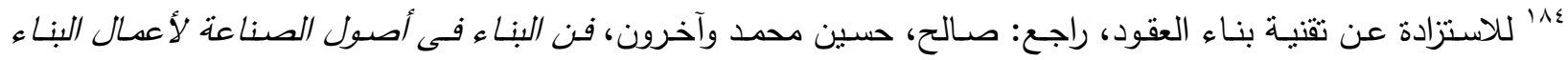

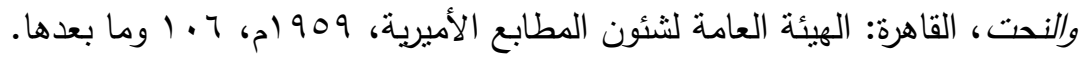

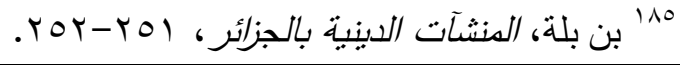


وفي مساجد ولاية طرابلس كانت الغلبة للعقد النصف دائري الذي استخدم بشكل رئيس فى بائكات غالبية

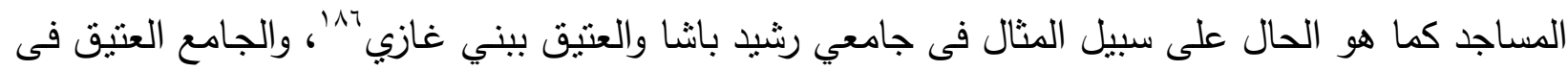

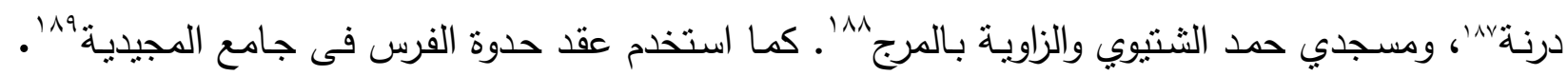

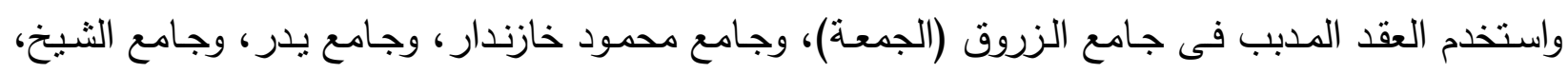

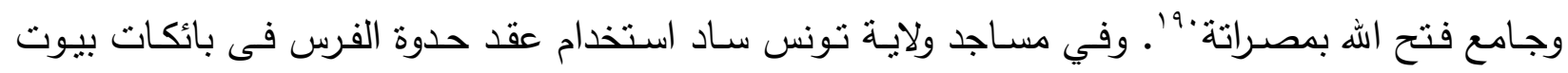
الصلاة والسقائف والأروقة الخارجية. كما استخدم العقد النصف مستدير لحمل القبة الرئيسة والقباب الصغيرة

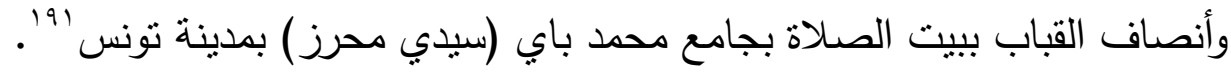

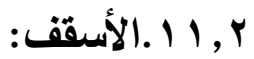

تتوعت الأسقق المستخدمة في المساجد بالمغربين الأدنى والأوسط خـال العصر العثماني، فوجدت

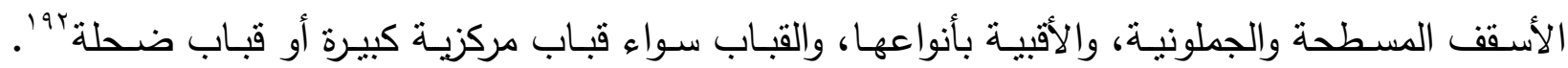

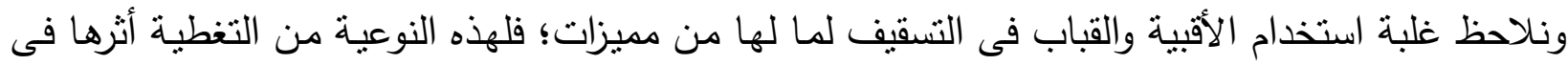

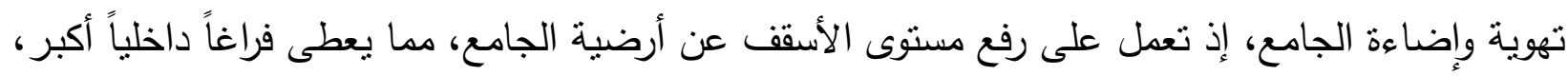

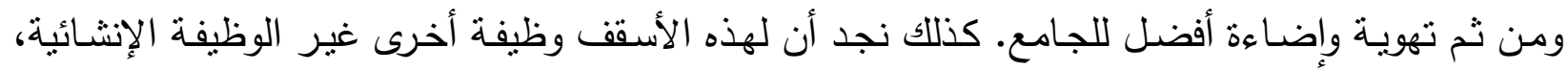

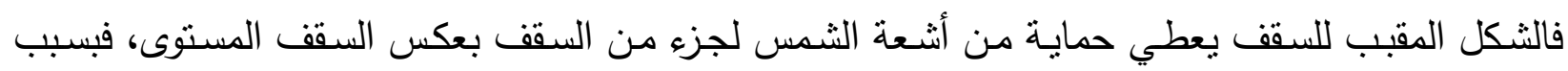

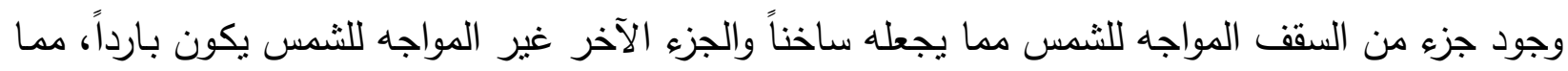
يساعد على تحريك الهواء لفرق الضغط بين المنطقتين الواقعتين أسفل هذين الجزعين بـ19 (شكل 9 (1) ). وقد حرص المعمار بالمغربين الأدنى والأوسط على استخدام الأقبية المتقاطعة والنصف اسطوانية فى لهى

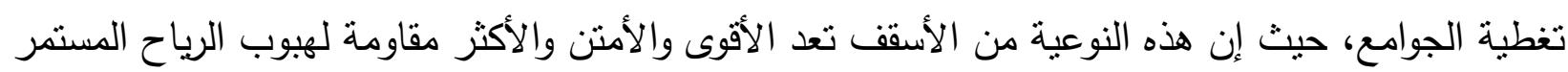
وسقوط الأمطار بغزارة معظم أوقات العام \1. وتغطية رواق الصلاة بالأقبية المتقاطعة من التقاليد الإفريقية

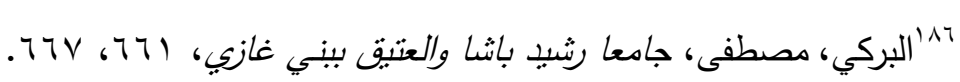

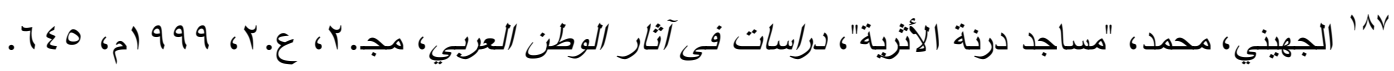
1^A

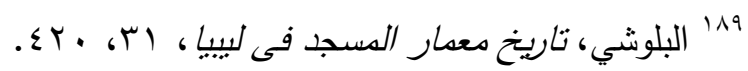

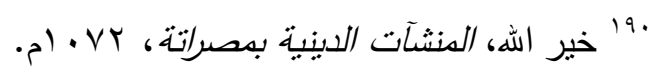

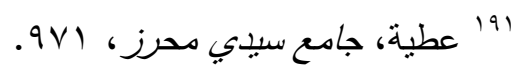
192 BUHLFAIA, Historical background of Libyan mosque architecture, 53-55 ; ALATRASH, Mosque Architecture in the Islamic Civilization in Libya, 96.

كوا عباس، سبد، "أثز البعد البيئي على تخطيط المدن والعمارة الإسـلامية"، مؤتمر الأزهر الهندسي الدولي التاسع، القاهرة،

$$
\text { . }
$$

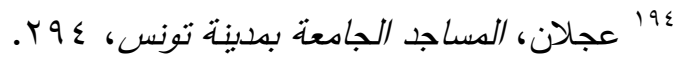


المحلية فى البناء، 190، حيث وجدت فى الأروقة الجانبية لجامع المهدية، كما استخدمت فى جامع صفاقس، وفى المسجد الجامع بسوسة. وكذلك الأمر بالنسبة للأقبية النصف اسطوانية والتى استخدمت في مسجد بو فتاتة، والمسجد الجامع بسوسة الذى جمع فى تسقيفه بين الأقبية المتقاطعة والأقبية النصف برميلية 197. وجدت هذه التغطية منذ فترات إسلامية مبكرة فى بعض العمائر الليبية، فقد ذكر البكري فى حديثه عن مدينة إجدابيـة الليبيـة، "وليس لمبـاني مدينـة إجدابيـة سـقوف خشـب، إنمـا هـى أقبـاء طـوب لكثرة رباحهـا ودوام

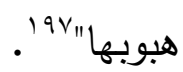

ولأقبية والقباب خاصية تأثيرية لما تُضفيه على البناء من هيبة وضخامة، فانحناء أو تجويف الأقبية والقباب له تأثير فى النفس أعمق بكثثر من تأثير الأسقف المسطحة و91. كما كان لهذه النوعية من الأسقق أثزها على عمارة المساجد بالمغربين الأدنى والأوسط، فالتغطية بالأقبية والقباب يحتاج إلى جدران قوية ذات أساسـات عميقة وسمك كبير لتتحمل التقل الواقع عليها، كذلك أثرت هذه النوعية من الأسقف فى ظهور الدعامات الساندة فى بعض الجوامع لتتحمل جدرانها جهد القوى الضـاغطة عليها من هذه الأسقف، مثنل الدعامات الساندة لجدران جامع سيقاط بجنزور (لوحة r). أمسا الأسقف المسطحة فأقل استخداماً مقارنة بالأقبية والقباب، ونجد استخدامها يقتصر على مساجد الطراز المحلى بالجزائر وبعض مساجد الطراز المحلي بليبيا ولتغطية بعض الأروقة الجانبية وبعض المرافق بباقي المساجد. ولعل هذا يرجع إلى أن الأسقف المسطحة لا تعطي فراغاً داخلياً كبيراً كالأقبية والقباب، ومن ثم إضاءة وتهوية أقل، وهو ما يتتاسب مع الوحدات الصغيرة والمرافق بالجوامع ، حيث إن المترددين عليها من النـاس أقل. ولعل اسـتخدام الأسقف المسطحة يرجهع إلى سـهولة تركيبها وقلـة تكلفتها مقارنـة بالأقيبـة والقباب.

195 BLAIR, S., \& BlOOM, J., The Art and Architecture of Islam, Yale university press, 1994, 114.

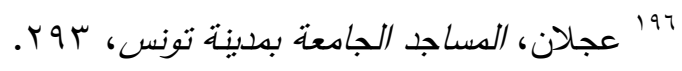

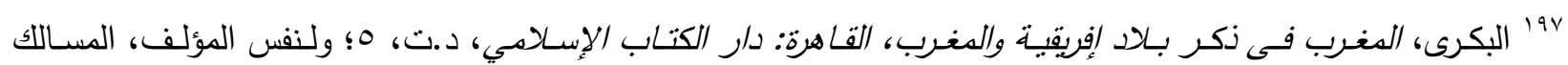

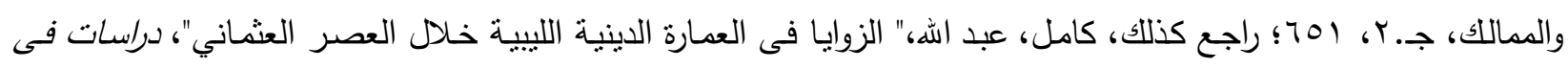

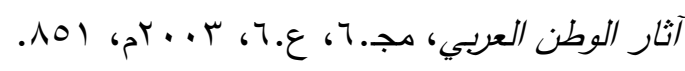

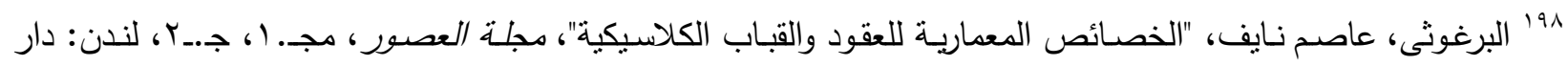

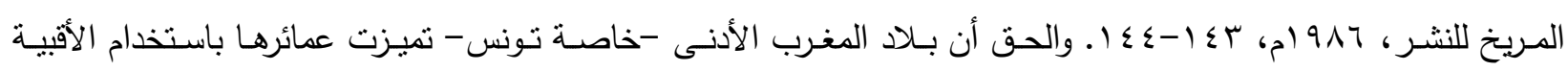
الحجريـة والآجرية وخاصسة المتقاطعة منها فى التسقيف، ولم نجد إلا نماذج نادرة للأسقف الخشبية كما فى جامعي القيروان والزيتونة، وهى تختلف فى ذللك عما استخدم فى عمائر المغرب الأقصى والأندلس والتى تميزت بتغطيتها بالأسقف الخشبية

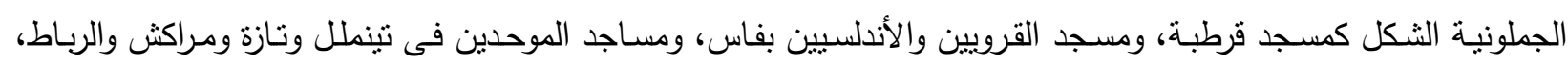

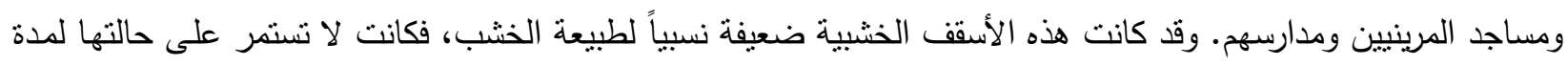

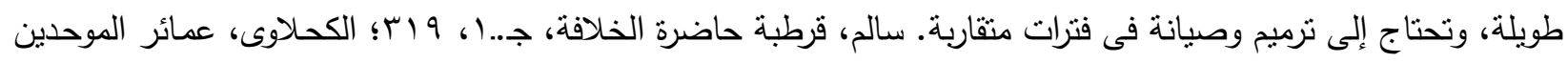

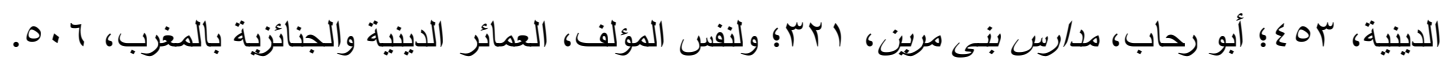


وفي ولاية الجزائر نلاحظ أن المساجد التى تتبع الطراز العثماني كانت تغطيتها الرئيسة عبارة عن قبة

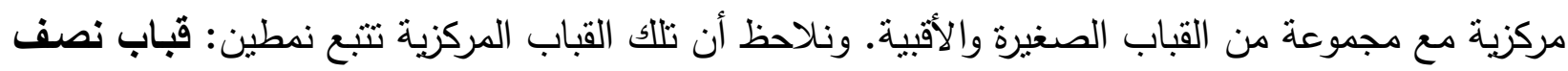

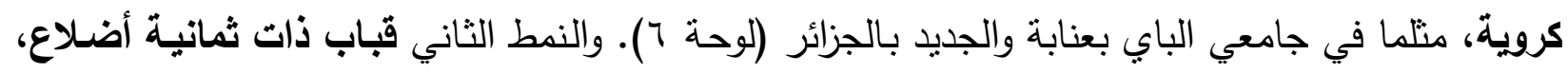

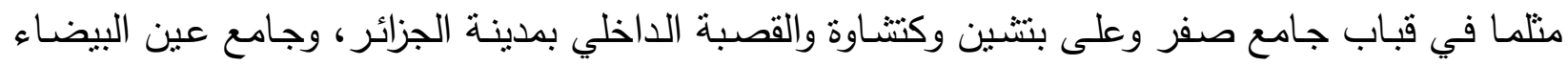
بمعسكر ـ وقد استخدمت هذه النوعية من التغطية - أب القباب ذات الثمانبـة أضـلاع - بكثرة فى العمارة

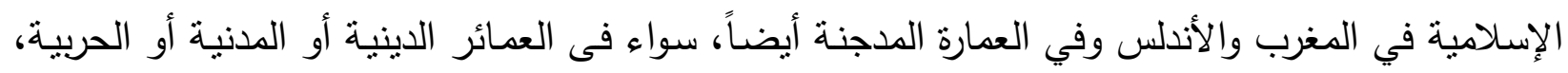

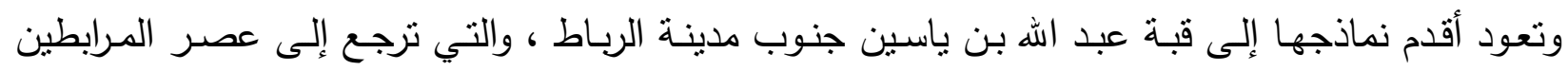

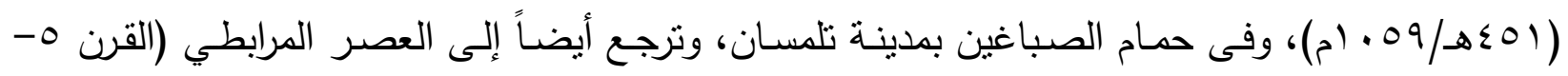

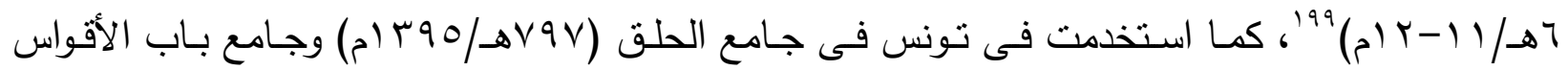

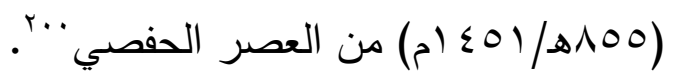

أما مساجد الطراز المحلي فاستخدم فيها أكثر من نوع من الأسقف، ولكن كانت الغلبة فيها للأسقف الخشبية المسطحة منلمـا فى جامعي سبدي لخضـر وسيدي الكتاني بقسنطينة، وجامع القصبة الخـارجي

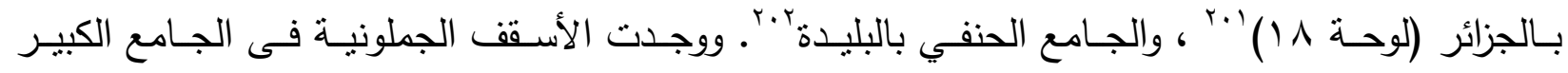

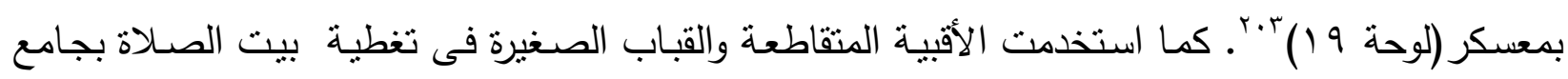
سوق الغزل بقسنطينة؛ +. واستخدمت الأقبية النصف اسطوانية فى جامع ابن سعدون بالبليدة، وفي تغطية

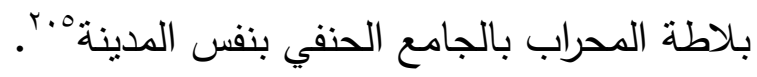

وفي ولاية طرابلس، فمن حيث التخطيط نجد أن جميع مساجد الطراز العثماني غطيت بالقباب (لوحة r، ז، ؟)، بينما مساجد الطراز المحلي غطيت بأقبية نصف اسطوانية وأسقف مسطحة.

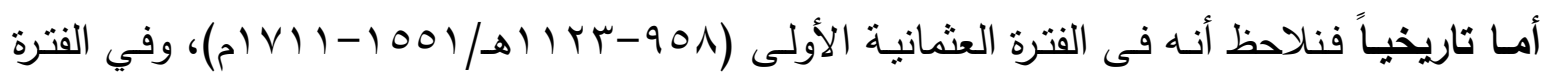

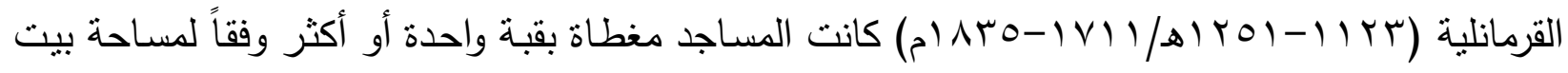

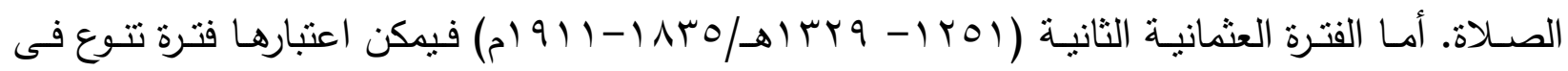
تخطيط المسجد الليبي وطرق تسقيفه، فوجدت مساجد سققت بقباب وأخري بأقبية نصف اسطوانية، ومساجد

199 ' للاستزادة عن هذه النوعية من القباب ونماذجها فى المغرب والأندلس، راجع: DOKMAK, A.: « La utilización de las partes de la bóveda de arista en la arquitectura islámica y mudéjar en Al-Andalua, norte de África y Sicilia », Anales de Historia del Arte19, 2009, 11-17.

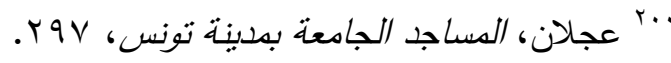

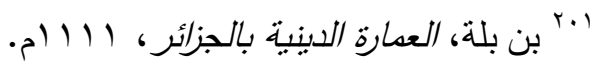

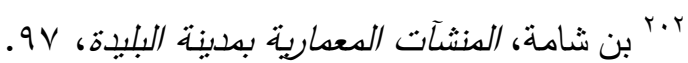

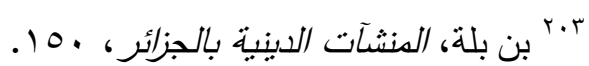

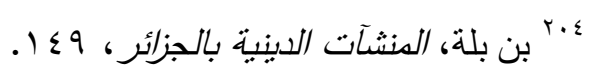

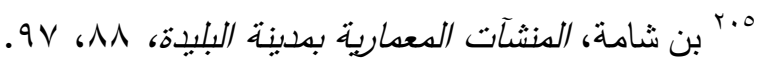


سقت بخليط من الأقبية والقباب. أما تغطية المساجد بأسقف مسطحة فهو تقليد معماري يميز كثيرًا من المساجد في كل الفترات قبل وأثناء الفترة العثمانية وبدون انقطاع r.r. وفي مساجد ولاية تونس تعد الأقبية الطولية والمتقاطعة هي وسيلة التسقيف الرئيسة مع وجود قبة تتقدم المحراب. حيث سفف جـامع يوسـف داي والجـامع الكبير فى بنـزرت بأقبيـة منقاطعـة. واستخدمت الأقبيـة الطوليـة فى تسقيف جامع حمودة باشـا والجامع الجديد وجامع يوسف صـاحب الطابع. ونلاحظ فى جامع

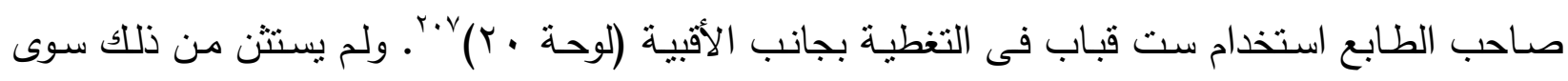
جامع محمد باي (سيدي محرز) والذي سقف بقبة مركزية وأربع أنصاف قباب وأربع قباب صغيرة فى الأركان (لوحة ه)^•r وجامع الباي بالقيروان والذي غطي بسقف خشبي مسطح، والذي بتألف فى الحقيقة من سقفين

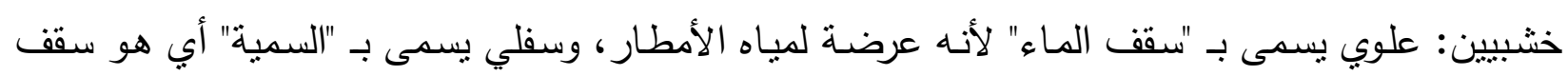

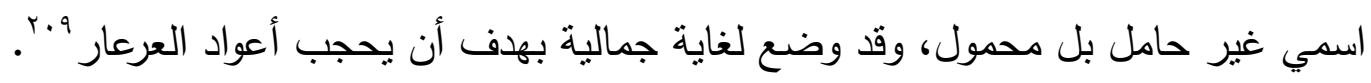

واستخدام قبة تتقدم المحراب فى التسقيف كان الغرض منها إبراز المحراب، فوجود القبة أعلى المنطقة التىى تتقدم المحراب هو نوع من التأكيد المعداري على إبراز هذا المكان، والذي حرص المعمار على إبرازه بشتى الوسائل؛ نظراً لكونه يحتوي من أسفل على المحراب والمنبر ، بجانب كونه الموقع المخصص لصصلاة الإمام والخليفةُ’’. كما جاءت نتيجة لحرص المعمار على إدراك تصميم للصوت فى رواق القبلة لتحسين اتصـال الخطيب أو الإمـام بالمصلين، فقد سـاعدت مـع عمق حنيـة المحراب والمجاز القاطع على تضخيم صوت الإمام ليصل إلى أكبر قدر من المصلين كما سبق ذكره. واستخدام قبة تتقدم المحراب في التشقيف وجد منذ العصور المبكرة في مساجد المغرب والأندلس، حيث ظهرت أقدم نماذجها بالمغرب الأدنى في

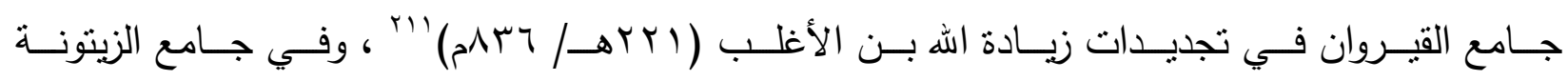

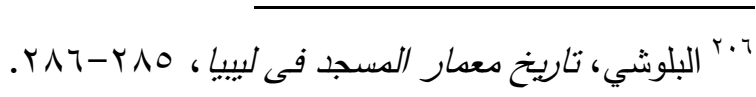

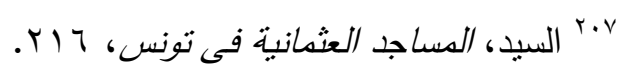

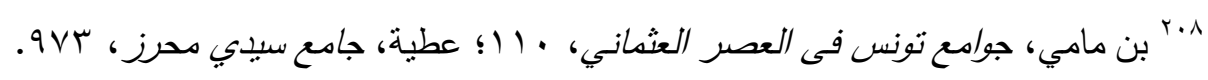

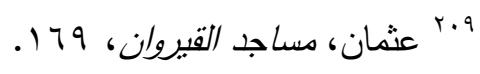

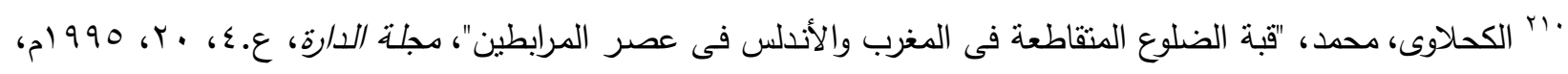

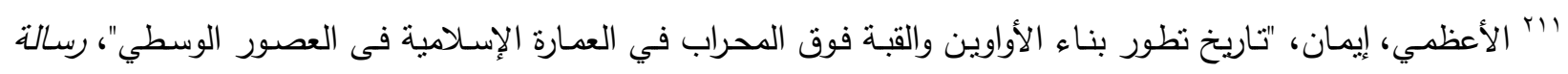

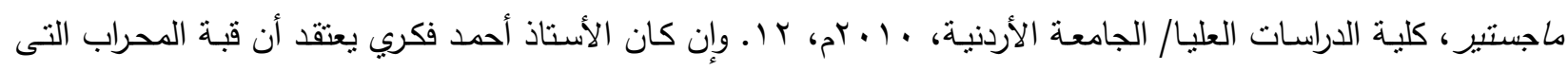

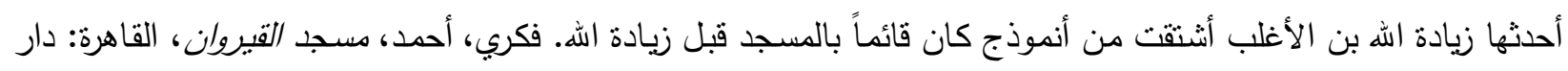

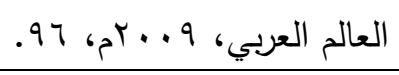




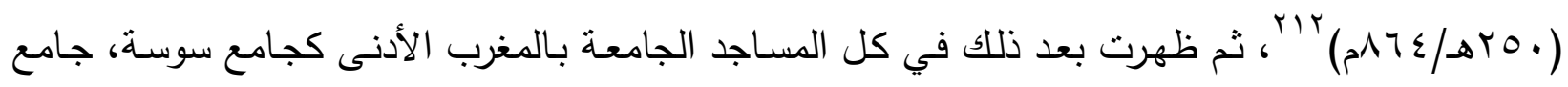

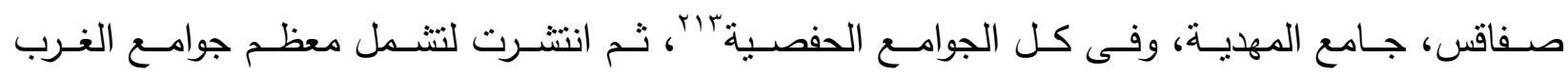
الإسلامي ءاr، وربما كان السبب في انتشارها بالمساجد المغربية - إضافة لوظائفها السابقة - هو لتزبد الفراغ

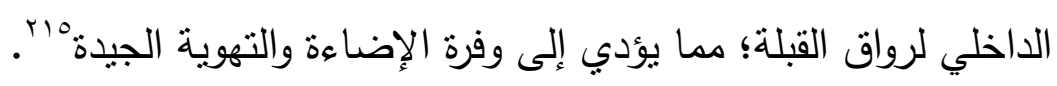

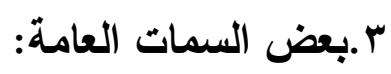

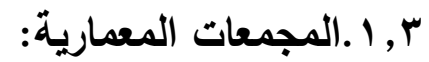

كان ظهور فكرة المجمعات المعماريـة ببلاد المشـرق الإسـلامي سـابقاً لظهورهـا ببلاد المغرب، حيث عرفت مصر هذه الظاهرة خلال العصر المملوكي، فقد كان يلحق بالجامع سبيل وكتاب وضربح ومساكن

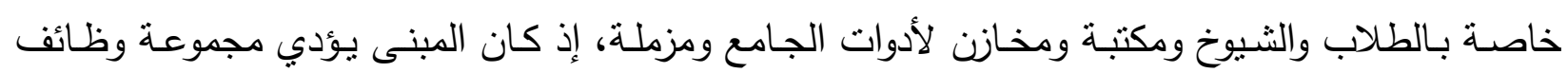
كالصلاة والتدريس والتصوف وغيرهاج" '. كما ظهرت المجمعات في بـلاد الأناضول في العصر السلجوقي،

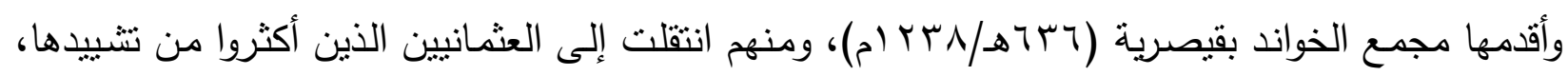

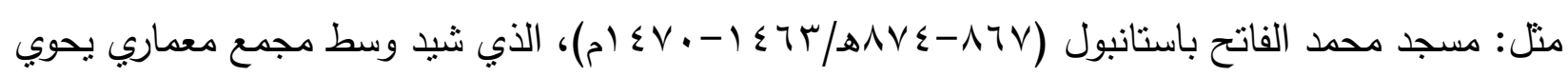
بالإضـافة إلى هذا المسجد ثماني مدارس ومستشفى وداراً للضيافة ومطعماً وخاناً، ومجمع السلطان بايزيد

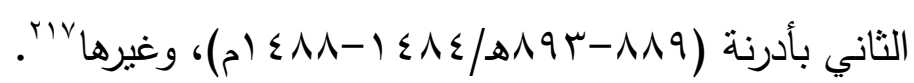

وفى الغرب الإسلامي عرفت المجمعات المعمارية قبل العصر العثماني، فقد ظهرت بالمغرب الأوسط

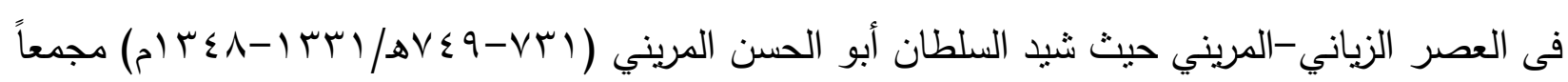

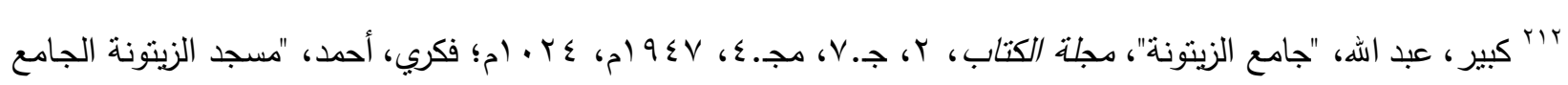

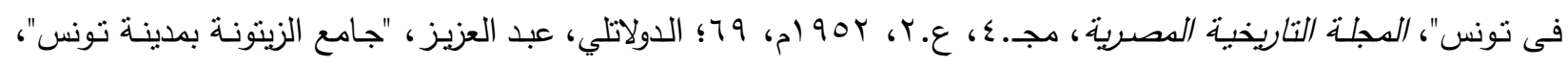

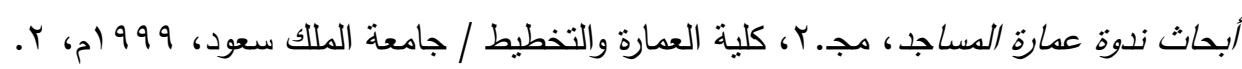

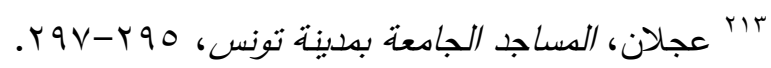
ءاب حيث ظهرت في المغرب الأوسط في جوامع كل من سيدي إبراهيم، سيدي بومدين، وسيدي الحلوي بتلمسان. وفي المغرب

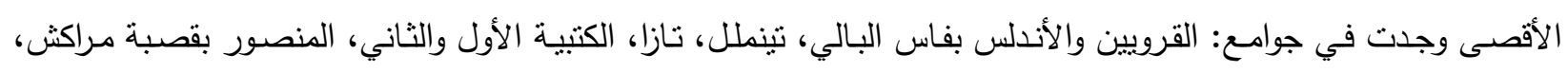

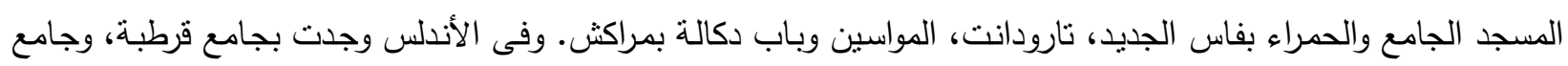
الموحدين بإشبيلية، وغيرها.

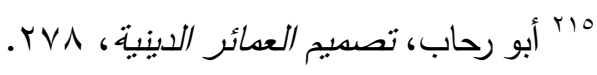

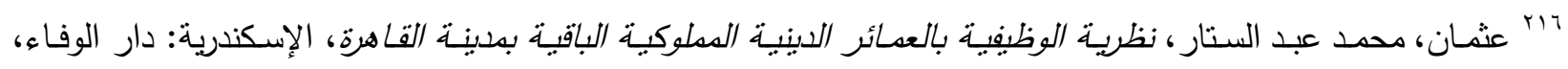
$r \cdot \Lambda \sin r .0$

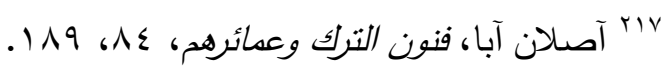




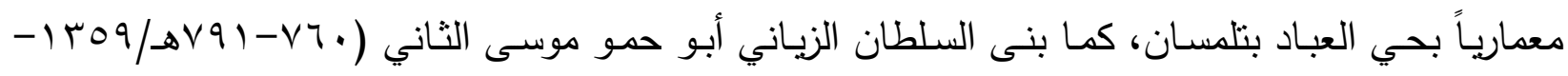

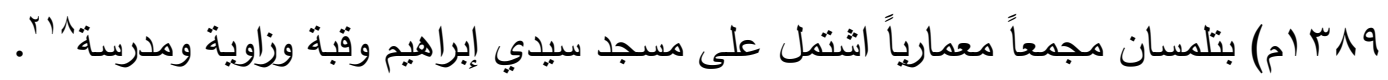

ومسع قدوم العثـانيين انتشـرت ظـاهرة المجمعات المعماريـة فى المغربين الأدنى والأوسط. ففي ولايـة

الجزائر تحققت فى كل من جامع سبدي لخضـر وجامع سبدي الكتاني بقسنطينة، وجامع عين البيضـاء بمعسكر، وجامع خنقة سيدي نـاجي ببسكرة. وقد ألحق بكل جامع من الجوامـع السـابقة مدرسـة وضريح أو وفئ

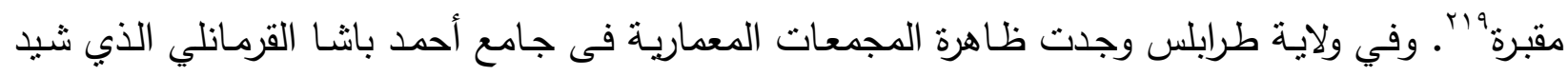
ضمن مجمع معماري كبير يشتمل على الجامع وضريح للمنشئ ومدفن لأفراد الأسرة ومدرسة من مستوبين،

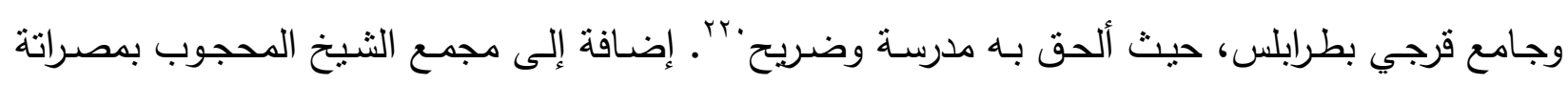
والذي يضم مسجداً جامعاً وزاوية كاملة المرافق وقبة ضريحية للمنشئ 'بr. وجامع مراد أغا فى ناجوراء كان يضم إلى جانب المسجد مدرسة وضربح، ويضم جامع درغوت باشا بطرابلس مدفناً يشتمل على مجموعة من من

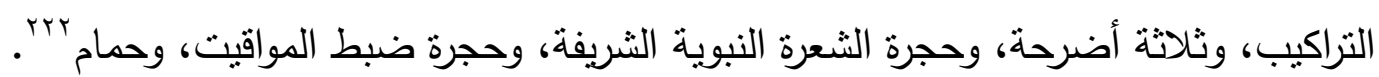

وفي ولايـة تونس وجدت المجمعات المعماريـة فى الجـامع الجديد بمدينـة تونس والذي يحتوي على

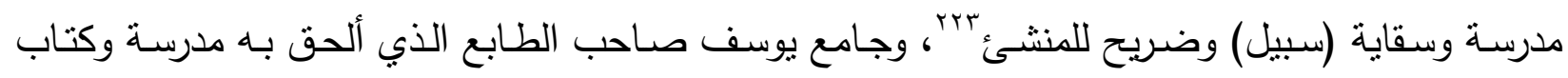

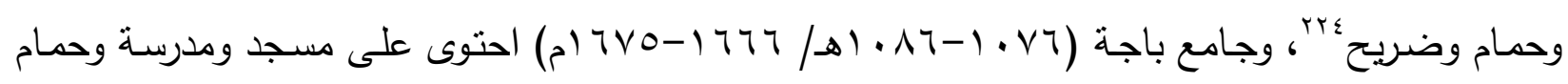

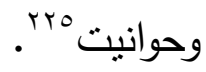

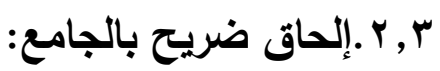

أشـارت أقوال الفقهاء إلى جواز إلحاق منشـأة دينية بالضريح أو العكس، ففي رسالة الثيخ إسماعيل التميمي التونسي ما يشير إلى "جواز البناء على القبور إذا كان حولها، كالقبة والبيت والمدرسـة، وكان ذللك فى ملك الباني"، وذهب اللخمي للمنع وذهب ابن القصار إلى الجواز ووافقه ابن رشد، أما فيما يتعلق باتخاذ المساجد على القبور فقد كان التحريم ظاهراً فى بداية عهد الإسـام حتى لا يعبد الناس الميت، ثم بعد أن

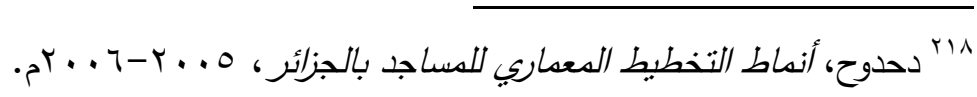

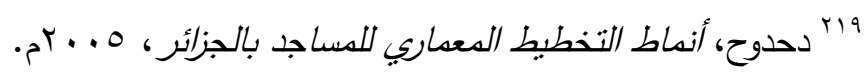

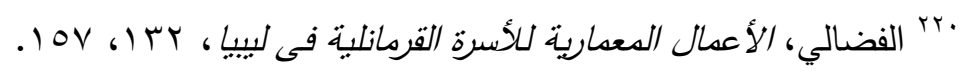

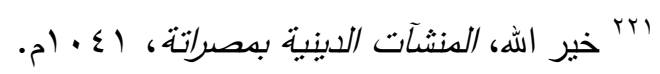

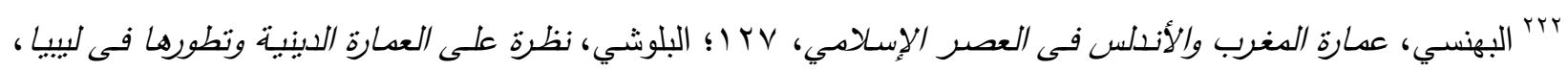

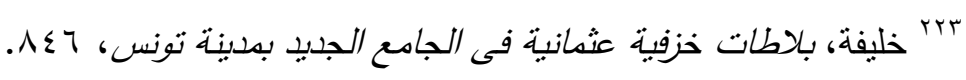

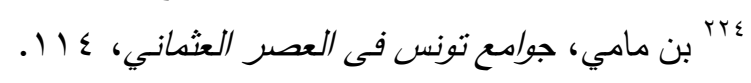

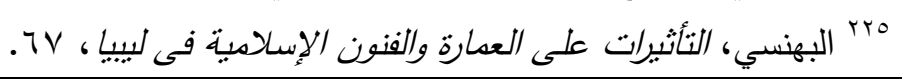




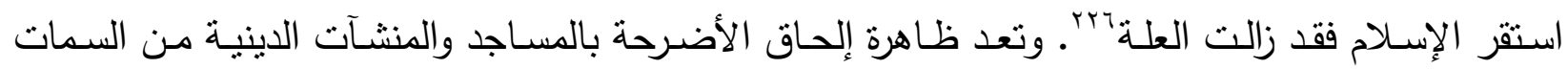

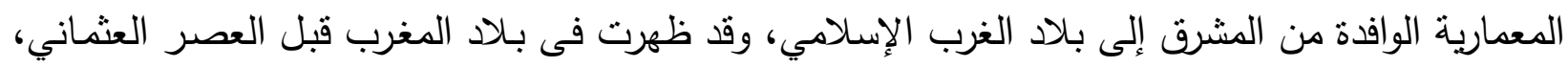

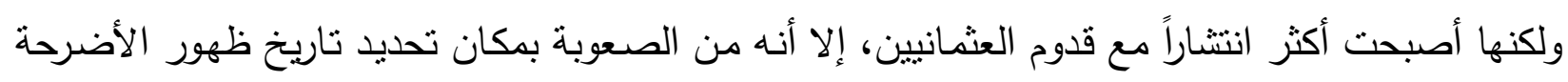

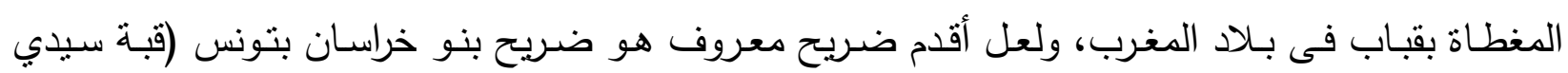

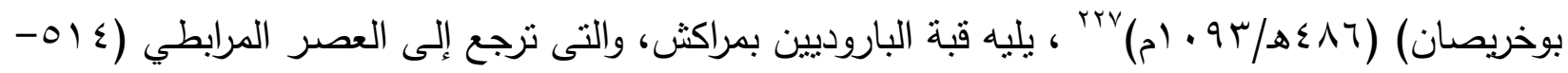

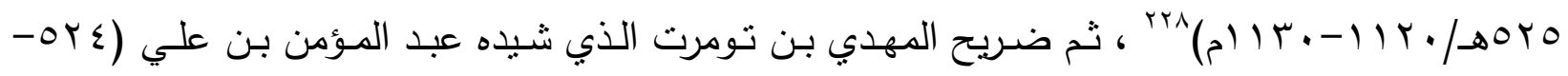

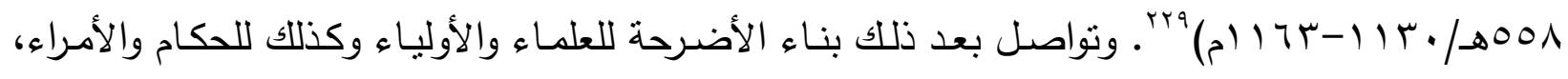

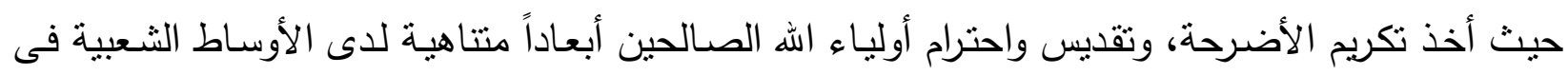

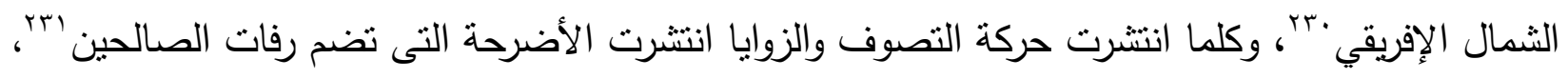

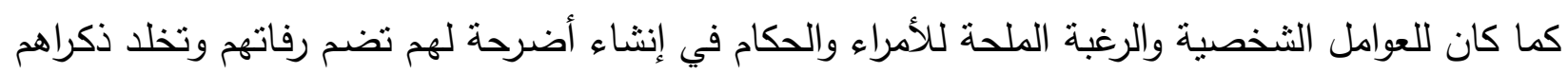

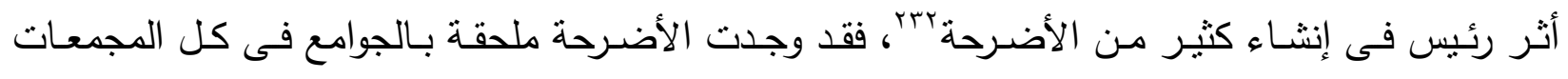

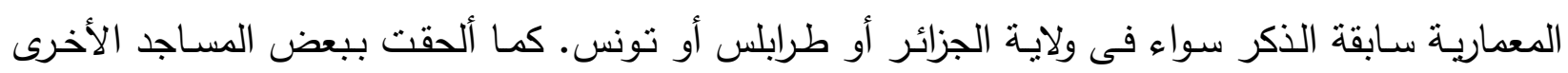
بخلاف المجمعات المعمارية. ففي ولايـة الجزائر هناك مسـد وضـريح سيدي عبد الرحمن الثنـالبي بrاب، وضـريح الجـامع الكبير

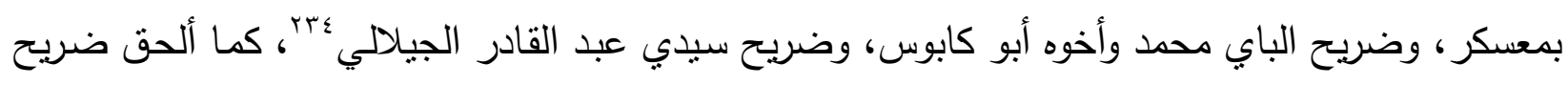

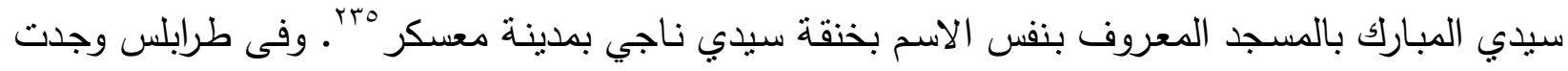

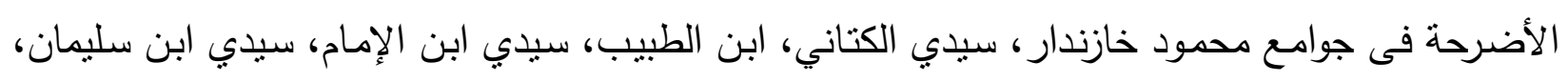

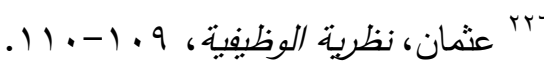

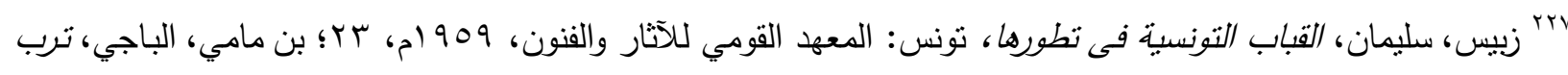

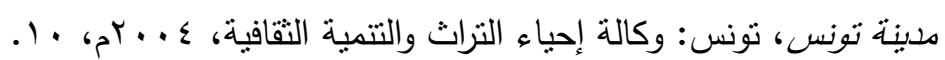

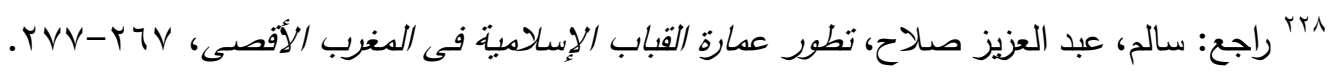

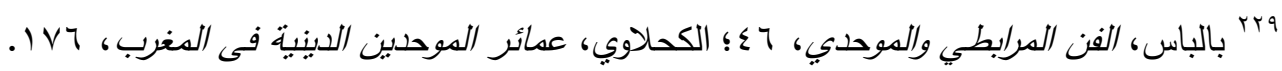

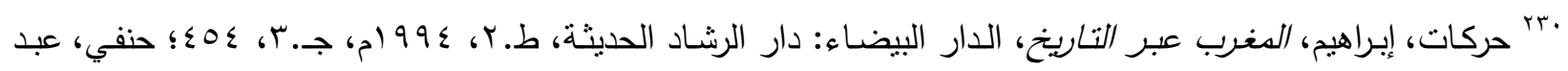

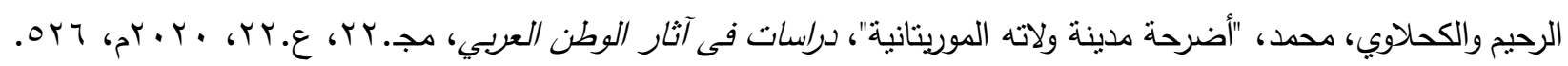

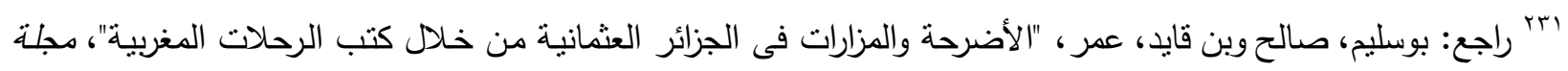

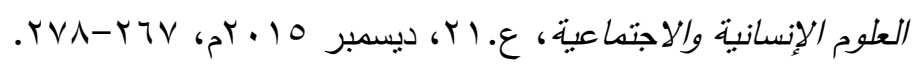
rrr

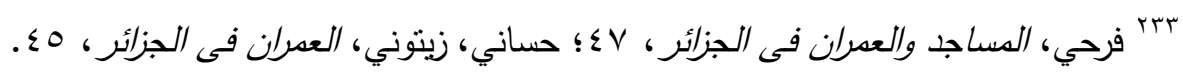

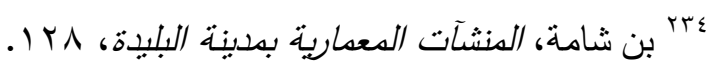

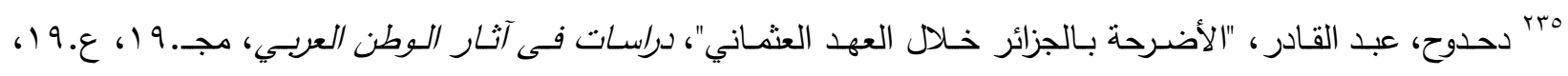


سيدي الحطاب، ابن موسي (ابن مقيل)، سيدي عطية الفلاح، سيدي جابر ، سيدي سالم المشاط، وغيرهابrr'. وفي ولايـة تونس أضيفت الأضرحة إلى كل من جامع يوسف داي (لوحة ( ())، جامع حمودة باشـا، جامع حسين بن علي تركي (الجامع الجديد)، وجامع يوسف صاحب الطابع بمدينة تونس.

وعن موقع الضريح بالنسبة للجامع الملحق به فقد تتوعت أماكنها، حيث وجدت ملاصقة لبيت الصـلاة أو بعيدة عنه إلى اليمين منه أو إلى اليسار أو فى الجهة المقابلة لرواق القبلة وفقاً لظروف المساحة والموقع فى كل جامع، وكان يراعى فى موقعها الأحكام الفقهية بحيث لا تكون خلف جدار القبلة ولا تشخل أي جزء من رواق الصلاة، وقد اتخذت جُل الأضرحة الملحقة بالجوامع تخطيطاً مربعاً تعلوه قبة، وهو من التأثنرات

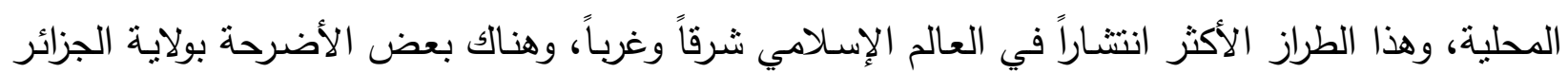
التى بُنيت على الطراز العثماني حيث اتبع تخطيطها نمط الأضرحة المفتوحة، منل الضربح الملحق بالجامع الأخضر ، وضريح سيدي الكتاني، والضريح بخنقة سيدي ناجي. ويتميز هذا النمط بوجود أربعة أعمدة أو دعامـات تعلوهـا قبـة أو سقف هرمسي أو مسنم وأحيانـاً سقف خشبي، وهذه الأعمدة إمـا تقوم على الأرض هل

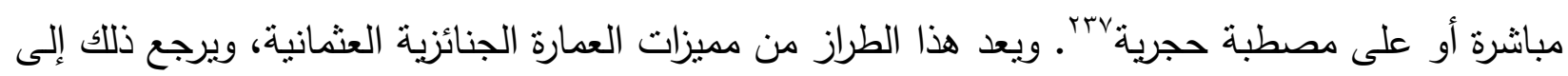
رشاقة هذا الثكل المعمارى مع بساطته وسهولة إنشائه وقلة تكلفته.

r, ب. المساجد المعلقة:

يطلق هذا النمط على المسـاجد التى تُبنى فى مستوى علوي، بينما يخصص مستواها الأرضـي إلى أغراض أخرى عادة ما تكون في شكل حوانيت ومرافق تجارية توقف على المسجد نفسه،، وقد لا تكون تابعة

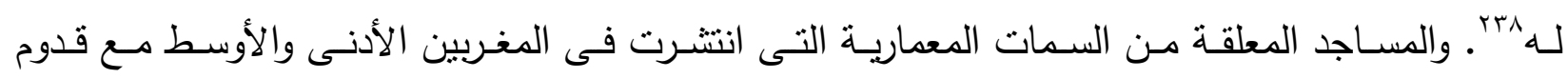
العثـانيين. وإن كانت هذه الظاهرة وجدت فى تونس قبل العصر العثماني، حيث عرفت فى مسـد ربـاط المنستير ومسجد رباط سوسة. وإن كانت الوظيفة هنا تختلف عن المساجد المعلقة التقليدية والتى تبنى أسفلها عادة حوانيت.

وسـاعد على وجود المساجد المعلقة فى المغربين الأدنى والأوسط بنائها وسط مناطق تجاريـة ذات

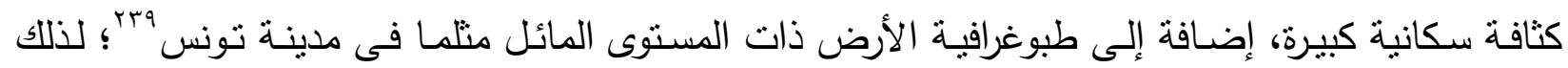

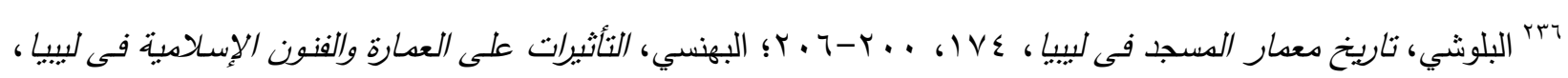
$. V \varepsilon-V \mu$

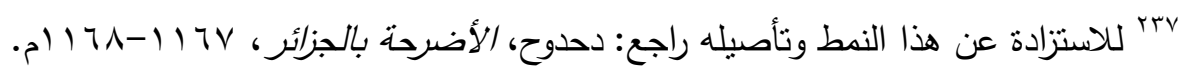

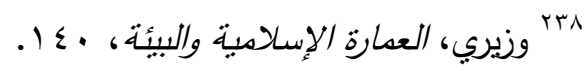

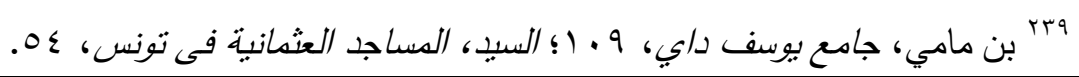


استغل المعمار المستوى السفلي فى تللك الجواهع بعدل حوانيت يصرف من ريعها على المسجد وإضـاءته

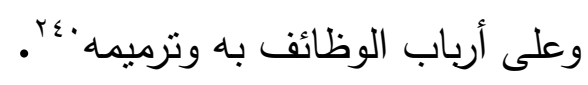

وظاهرة المساجد المعلقة من السمات المعمارية العثمانية التى ميزت عددًا من المساجد بالجزائر خلال

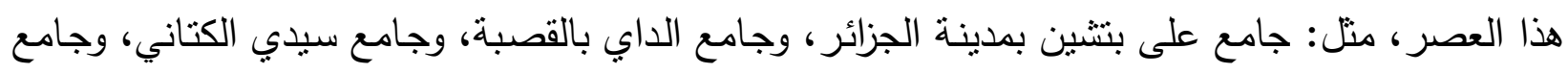

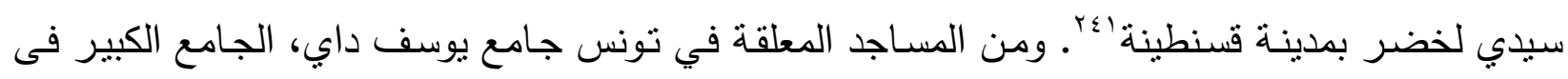

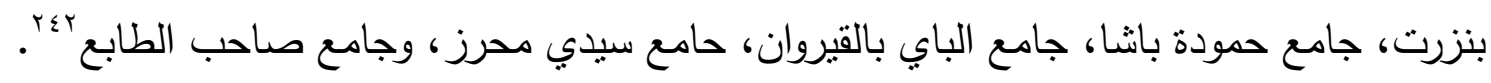

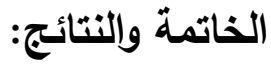

اتضح من خلال العرض السابق أن المغربين الأدنى والأوسط قد ازدانا خلال العصر العثماني بعدد

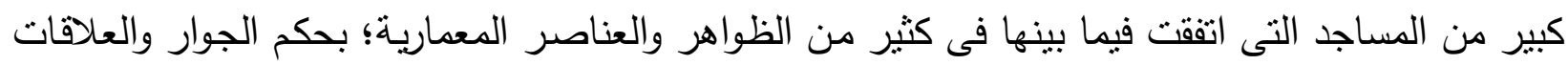

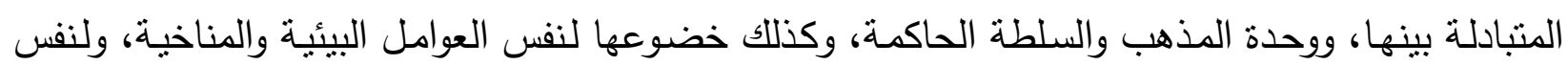

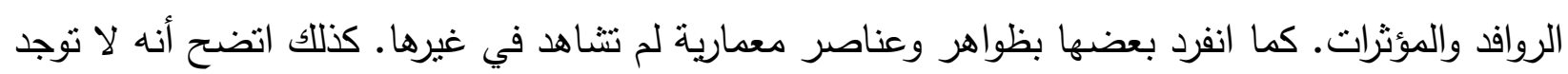

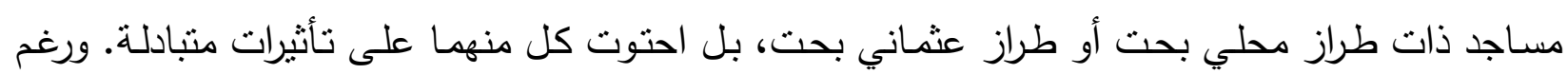

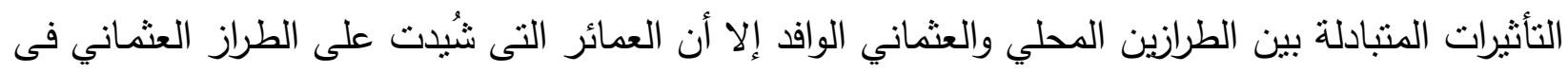

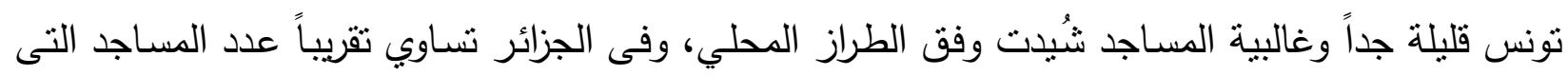

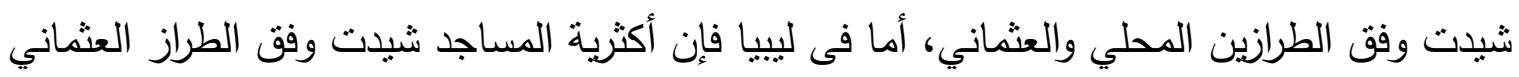

•؛ أبو طاحون، إبراهيم، "الجوامع المعلقة بمدينة طرابلس الثـام فى العصر العثماني"، دراسات فى آثار الوطن العربي،

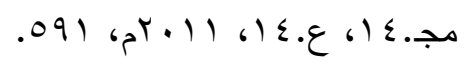

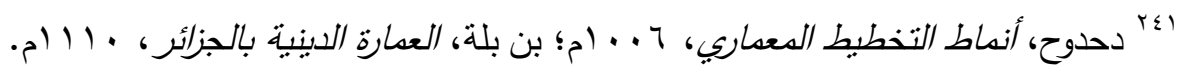

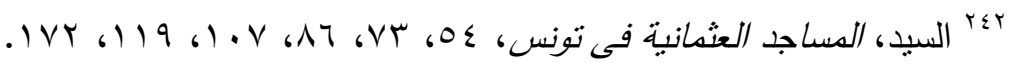




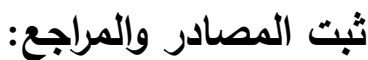

\section{أولاً: المصادر والمراجع العربية:}

-إبراهيم، فهيم فتحي، "أضـواء جديدة على المساجد السلجوقية فى بـلاد الأناضـول، مؤتصر : عمارة المساجد في الحضـارة

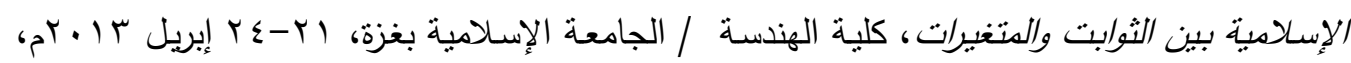

$.99-0 \mathrm{~V}$

-IBRĀHĪM, FAHĪM, «Aḍ̂ā’ ğadīda 'alā al-Masāğ̄̄d al-Sūlğūqīya fī bilād al-Anāọūl»,

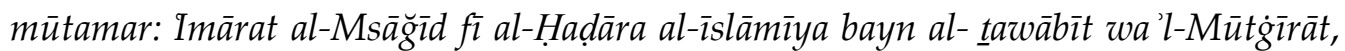
Faculty of Engineering/ The Islamic University of Gaza, 21-24 Avril 2013, 5799.

-.......................... دراسة مقارنة لأساليب التخطيط في العدائر الدينية السلجوقية والمصرية حتى نهاية العصر المهلوكي،

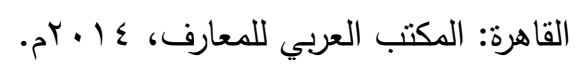

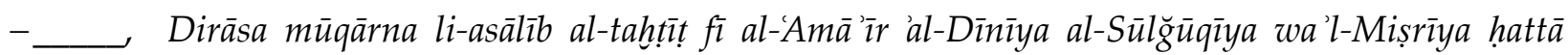
nīhayat al-Assr al-mamlūkē, Cairo: al-Maktab al-Arabī lī'l-M'ārīf, 2014.

- إسماعيل، عثمان، تاريخ العدارة الإسـامبية والفنون التطبيقية بالهغب الأقصس، جـ.ه، الرباط: مطبعة المعارف الجديدة، .

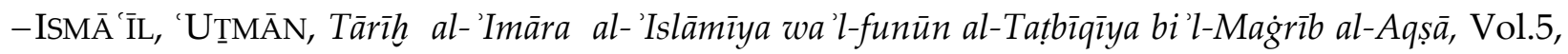
Rabat: Mațba at al-Ma ārīf, 1993.

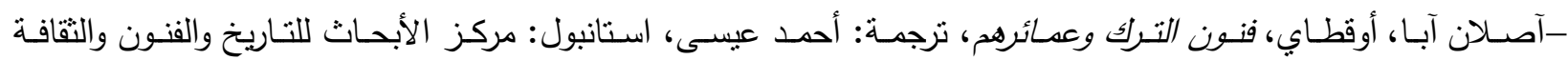

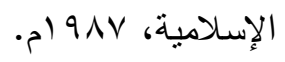

-OKTAY, ASLAN ABA, Funūn al-Tūrk wa ámā'ìruhūm, Translated by: Aḥmād 'Isā, Istanbul: markaz al-abḥāt lî̀'l-tārīh wa'l-funūn wa'l- taqāfa al-Islāmīya, 1987 .

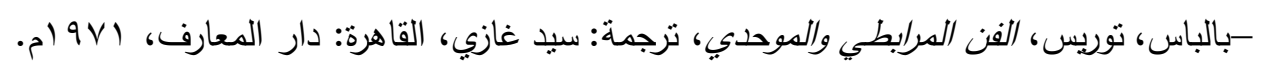

-BALBAS, TORIS, al-Fan al-Mūrābțī wa'l-Muwahidì, Translated by: Sayid Ġāzī, Cairo: Dār alM`ārīf, 1971

- برنشفيك، روبار ، تاريخ إفريقية في العصر الحفصي، نرجمة: حمادي الساحلي، بيروت: دار الغرب الإسلامي، 911 ام.

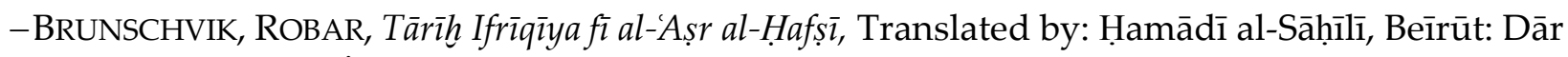
al-Ġarb al-Islāmīi, 1988.

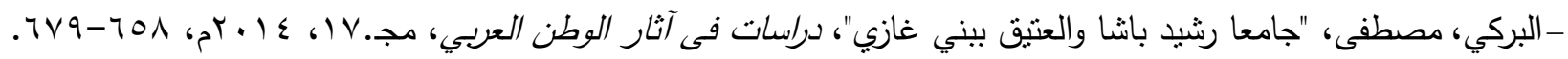
10.21608/CGUAA.2014.43287

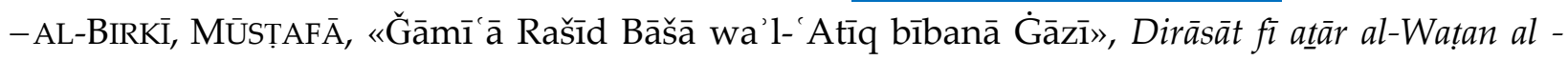
Arabī17, 2014 658-679.

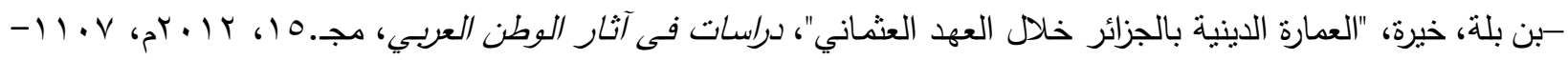
10.21608/CGUAA.2012.34400.م 11 1

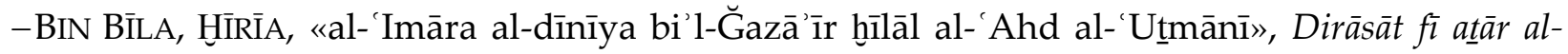
Wațan al - Arabī15, 2012.

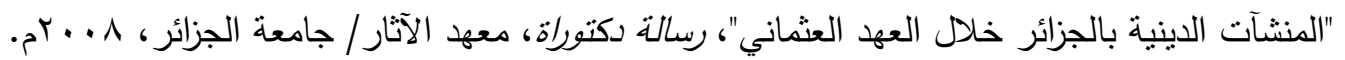

, «al-Mūnša' āt al-Dīnīya bi'l-Ğazā'īr ḩ̄ilāl al- 'Ahd al- 'Utimānī», PhD Thesis, Institute of Archeology/ University of Algiers, 2008. 


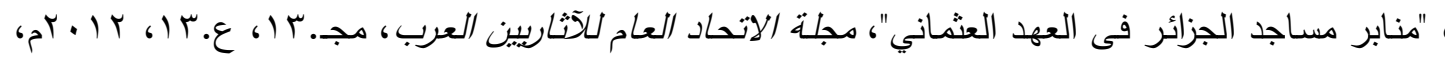

\subsection{8/IGUAA.2012.2919.1 $79-1 \leqslant 7$}

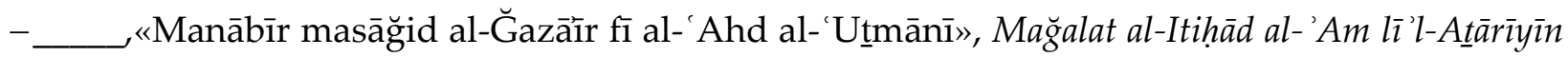
al-'Arab13, 2012

-البلوشي، علي مسعود، تاريخ معدار المسجد في لبييا فى العهدين العثماني والقرهنلي، طرابلس: منشورات جمعية الدعوة

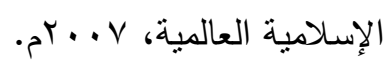

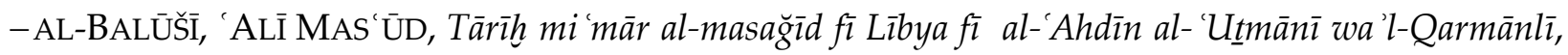

Tripoli: Manšūrāt Ğam iyat al- D'awa al-Islāmīya al-Alamīya, 2007.

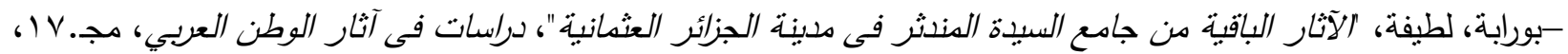

10.21608/CGUAA.2014.43267.01r-071 ،

-BŪRĀBA, LAṬīFA, «al-Atāar al-Bāqya min ğāmī' al-Sayida al-Mūndatīr fī madīnat al-Ğazā'īr al-

'Uțmānīya», Dirāsāt fì ațār al-Wațan al - Arabī17, 2014, 568-582 .

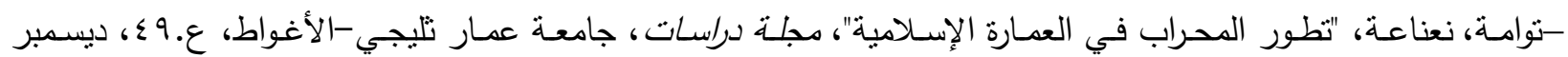

$$
\text { .0r-r t } 17
$$

-TAWĀMA, NI'NĀ'A, «Tațawur al-Mīhnāb fī al-'īmāra al-islāmīya», Dirassat revue international49,

Ammar Telji University - Laghouat, 2016, 26-53.

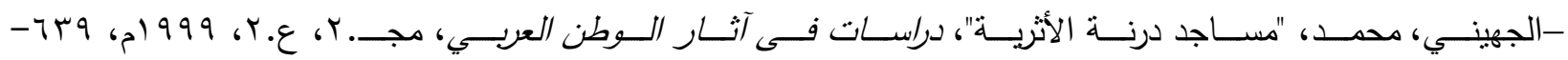

\subsection{8/CGUAA.1999.40844 . ^^ᄉ}

-AL-ĞŪHAYNī, MuHAMMAD, «Masāğ̄̄id Dirna al-atāāīya», Dirāsāt fì Ațār al-Watan al -'Arabī 2, 1999.

-حاج سعيد، محمد، "مساجد القصبة فى العهد العثماني"، رسالة ماجستبر، كلية العلوم الإسلامية/ جامعة الجزائر ، 10 • بام. -Ḥ̂ĀĞ SA İD, MuḤAMMAD, «Masāğid al-Qașaba fī al-'Ahd al- 'Utimānī», MasterThesis, Faculty of Islamic Sciences/ Algeria University, 2015 .

-الحداد، محمد حمزة، موسوعة العمارة الإسلامبية فى مصر من الفتح العثانى حتى عهر محد علي، الكتاب الأول (المدخل)،

$$
\text { القاهرة: مكتبة زهراء الثرق، } 991 \text { ام. }
$$

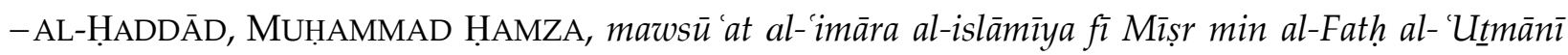
hattā 'ahd Muhammad 'Alī , the first book (Introduction), Cairo: Maktabīt Zahrā' al- Šarq, 1998.

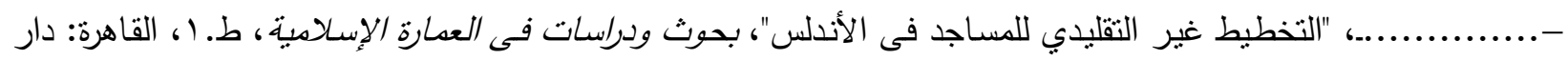

$$
\text { نهضة الشرق، .... }
$$

«al-Tahțịt gayr al-Taqlīdī li'l-Msāğīd fī al-Andalūs», Buḥ̂ut wa dirāsāt fì al-`imāra alislāmìya, Cairo: Dār nahḍat al-Šarq, 2000, 161-195.

-حسـاني، فريدةو زيتوني، شـهيرة، "العمـران فى الجزائر خـلال العهد العثـاني"، رسالة ماجستبر ، كليـة العلوم الإنسـانية

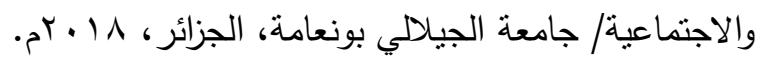

-ḤASSĀNī, FARĪDA \& ZAYTŪNĪ, ŠAHĪRA, «al-Umrān fī al-Ğazā'īr hīlāl al-'Ahd al-'Utmānī», Master Thesies, Faculty of humanity and sociology Sciences/ University of Djilali in Bounaama, Algeria, 2018.

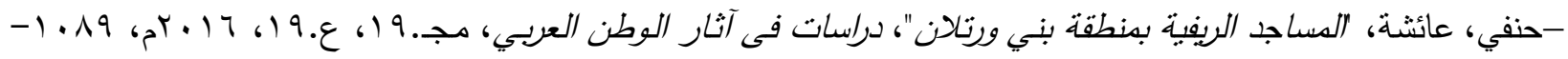
$\underline{10.21608 / C G U A A .2016 .29598} \cdot p 1110$

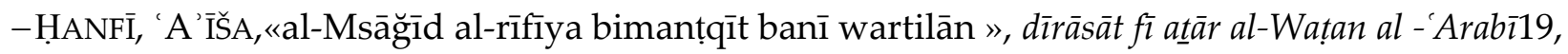
2016. 


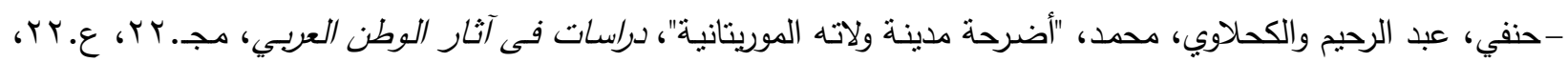

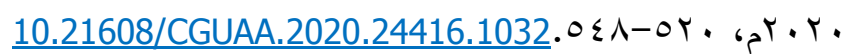

-ḤANFī, 'ABD AL-RīHĪM \& \& AL- KAHLĀWĪ, MuHAMMAD, « Aḍriḥat madīnat walāta alMūrītānīya», dīrāsāt fì ațār al-Wațan al -'Arabī 22, 2020.

-الخازمي، محمد، "المآذن الليبية فى العصر العثماني"، رسالة ماجستير، كلية الآداب والعلوم بالخمس/ جامعة المرقب، ليبيا، .

-AL-HֵĀZMī, MuḤAMMAD, «al-Ma'ād īn al-Lìbīya fī al- Aṣr al- 'Uțmānī», Master Thesis, Faculty of Arts and Sciences of Khamsa / Al-Muraqab University.-Libya, 2018.

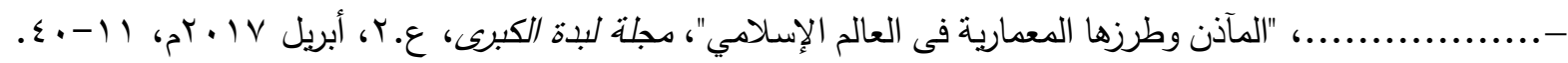
«al-Mayād īn wa țuruza al-mi 'mārīya fī al-'Alm al-Islāmī», Mağlat labda alkūbra2, Abril 2017, 11-40.

$$
\text { -خلاصي، علي، قصبة مدينة الجزائر، الجزائر : دار الحضارة للنشر والتوزيع، V. - rم. }
$$

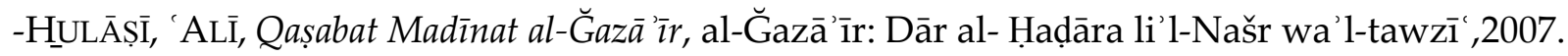

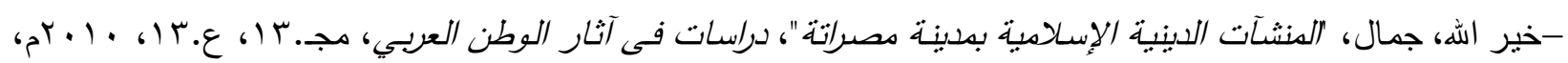
10.21608/CGUAA.2010.37076 • $11 \cdot v-1 \cdot r$

-HูAYR ALLAH, ĞAMĀL, «al-Mūnša'āt al-Dīnīya al-islāmīya bimadīnat Muṣrāta», Dìrāsāt fì atâ̄r al-Wațan 'al -'Arabī 13, 2010.

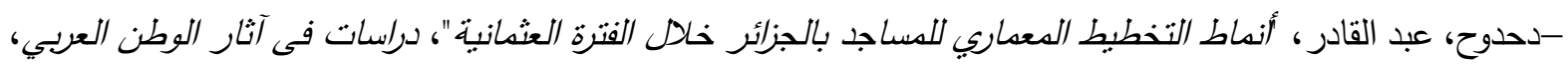

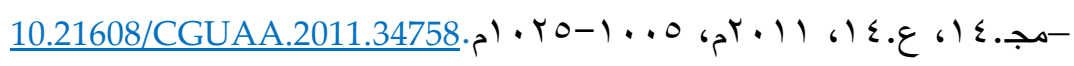

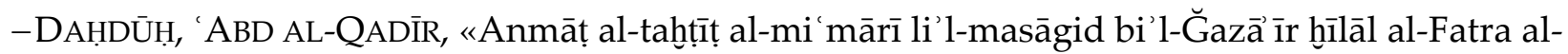
'Uțmānīya», Dirāsāt fì ațār al-wațan al -'Arabī14, 2011.

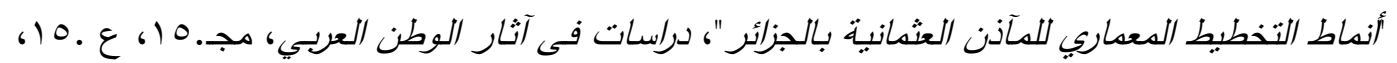

\subsection{8/CGUAA.2012.34703 •}

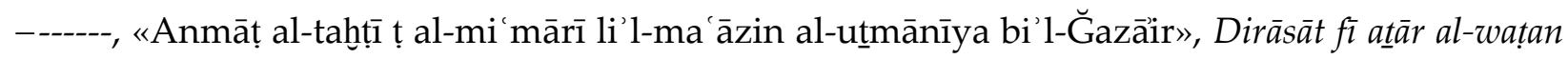
al-'Arabī 15, 2012.

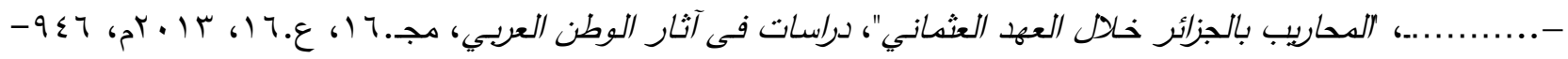
10.21608/CGUAA.2013.32183 . . 9 ^

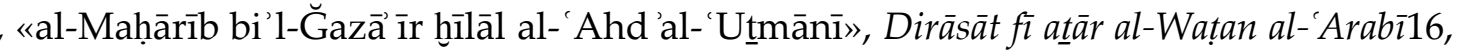
2013.

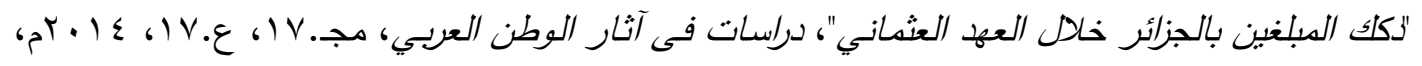

\subsection{8/CGUAA.2014.42679. ₹ ) V-rq}

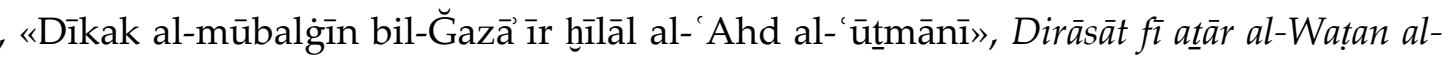
'Arabī 17, 2014.

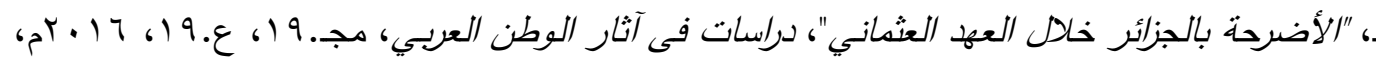

$$
\underline{10.21608 / C G U A A .2016 .29625} \cdot \text { • } 111 \cdot-11 \leq 7
$$

, «al-Aḍihha b 'il-Ğazā'īr hōilāl al- 'Ahd al- 'Utmānī», Dirāsāt fì ațār al-Wațan al-'Arabī19, 2014.

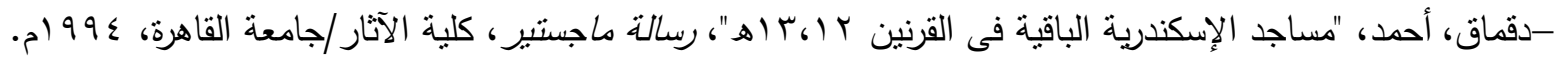
-DŪQMĀQ, AHMĀD, «Masāğid al-iskandarīya al-Bāqīya fī al-Qarnīn 12,13h», Master thesies, faculty of archaeology/ Cairo University, 1994. 


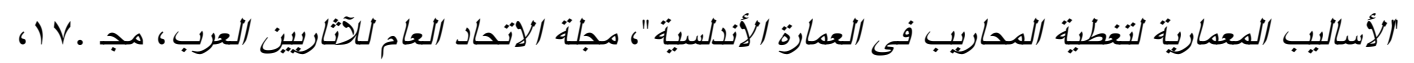

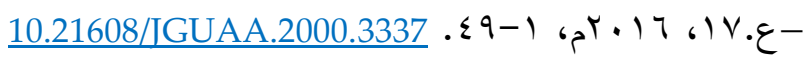

--------, «al-Asālīb al-mi 'mārīya litag̣țiyat al-mahārīb fī al- 'īmāra al-Andalūsīya», mağlat 'al- 'ìthāed al- 'Ām lī'l-'A Atārìȳinn 'al-'Arab, vol.17, 2016.

-الدولاتلي، عبد العزيز، مدينة تونس فى العُد الحفصي، ترجمة: محمد الثابي وعبد العزيز الدولاتلي، نونس: دار سراس للنشر،

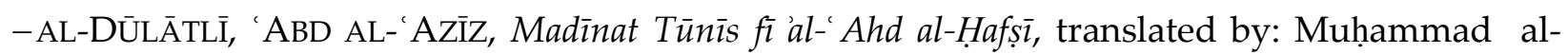
Šabī, \& 'Abd al-'Azīz, ' al-Dūlātly, Tunisia: Dār sīrās līl- Našr, 1981.

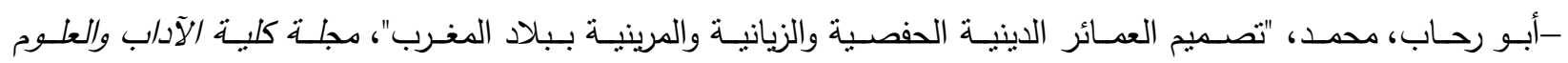

الإنسانية/جامعة سبيدي محد بن عبد الله بفاس، Vra

-ABŪ RīHĀB, MuHAMMAD., «Taṣmīm al- 'Amā'īr al-Dīnīya al-Ḥafṣīya a wa'l-zaīyānīya wa'lmarīnīya bibilād al-maġrib», Journal of the Faculty of Arts and Humanities / University of Sidi Mohamed bin Abdullah in Fez 37, №. 1, 2015.

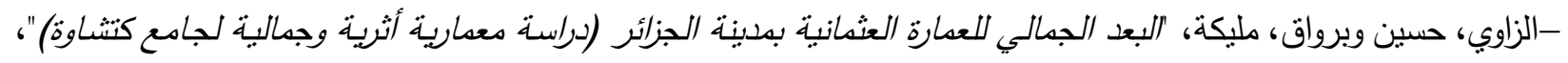

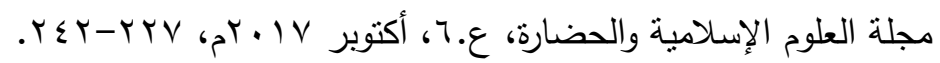

-AL-ZĀWİ, ḤŪSAYN WA-BRŪĀQ MALĪKA, «al-Bū 'ad al-Ğmālī li' l- 'imāra al- 'Uțmānīya bi-Madīnat al-Ğazā'̂̄r», Mă̆lat al- 'ūlūm al-islāmìya wa'l-Had̄âra 6, 2017.

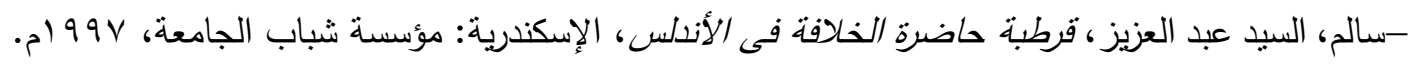

-SALĪM, AL-SAYID ABD AL-'AZĪZ, Qūrțūba hạḍ̂̀rat al-Hīlāafa fì al-Andalūs, Alexandria: Mūāssat šabāb al-Ğāmī'a, 1997.

-السيد، مي،"المساجد العثمانية فى تونس دراسة أثرية مقارنة مع منيلاتها بمدينة القاهرة"، رسالة دكتوراة، كلية الآداب/ جامعة

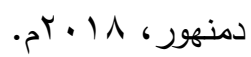

-AL-SAYID, MAY, «al-Masāğid al- 'Uțmānīya fī Tūnīs dirāsa ațārīya mūqārna ma 'a mațīātīhā bimadīnat al-Qāhīra», PhDTheseis, Faculty of Arts/ Damnhūr Univirsty., 2018.

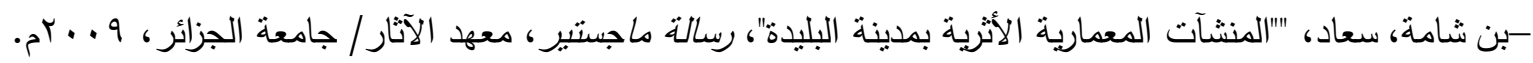
-BIN ŠĀMA, SŪ ĀD, «al-Munša’ āt al-Mi 'mārīya al-atāāīya bimadīnat al-Bulayda», Master thesies, Institute of Archeology/ University of Algiers, 2009.

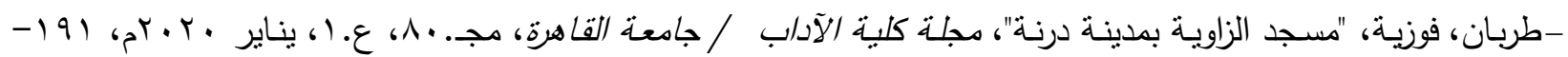

\subsection{8/JARTS.2020.83908 - Y T}

-TŪRBĀN, FAWZĪYA, «Masğid al-zāwīya bi-madīnat Dīrna», Journal of the Faculty of Arts/ Cairo University 80, №. 1, 2020.

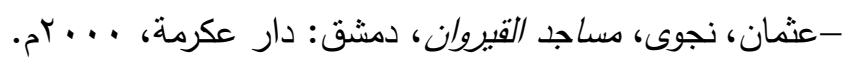

- 'UṬMĀN, NAĞWĀ, Masāgid al-Qaīrwān, Damascus: Dār 'Ikrima, 2000.

-عجـلان، عـامر،" المسـاجد الجامعـة بمدينـة تونس فى العصر الحفصي"، سـالة ماجستبر، كلية الآداب/ جامعـة سوهاج، $.5 r+11$

- 'AĞLĀN, 'AMER, «al-Msāğid al-ğāmi a bi-madīnat Tunīs fī al-'Așr al-Ḥafṣì», MasterTheseis, Faculty of Arts/ Sohag University., 2011.

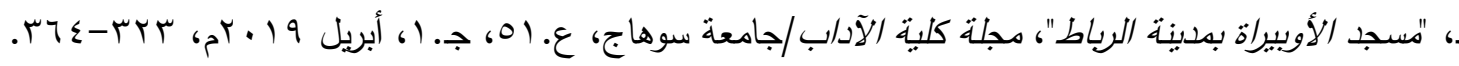
«Masğīd al-Ubīrā bimadīnat al-Rībāt», Journal of the Faculty of Arts/Sohag University 51, №.1, Avril 2009. 


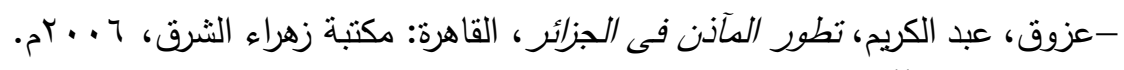

- 'AZŪQ, 'ABD AL-KARĪM, Tațawūr al-m'azīn fì al-Ğazā 'ìr, Cairo: Maktabat Zahrā' al-Šarq, 2006.

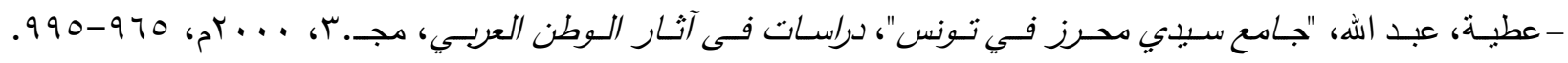

\subsection{8/CGUAA.2000.42105}

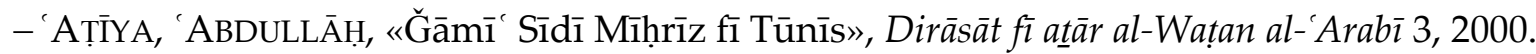

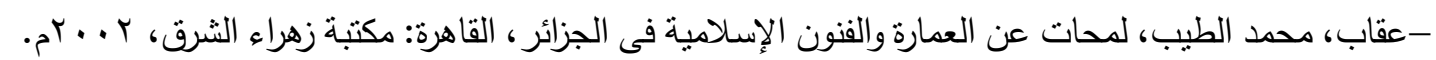

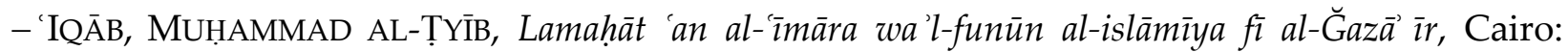
Maktbīt Zahrā' al-Šarq, 2002.

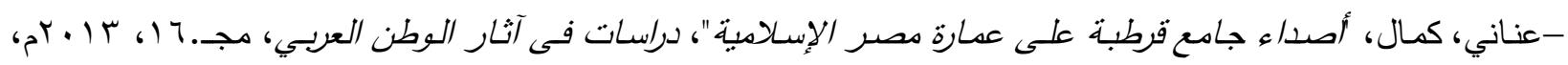
10.21608/CGUAA.2013.32364 •p $111 \mathrm{V-1 \cdot VV}$

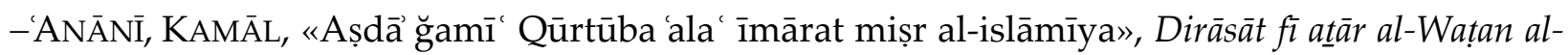
'Arabī16, 2013.

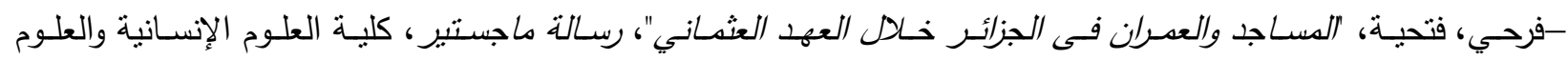

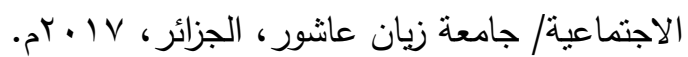

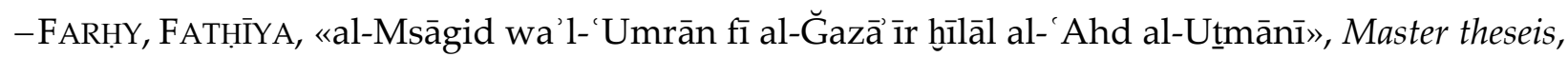

Faculty of humanity and sociology Sciences/ Ziane Achour University, Algeria, 2017.

-الفضالي، عبد العزيز، الأعمال المعدارية للأسـرة القرمانلية فى لبييا"، رسالة ماجستير ، كليـة الآداب/ جامعة الإسكندرية، $.0 r \cdot 11$

-AL-FAḌ̄LĪ̃, 'ABD AL- AZĪZ, «al-A 'māl al-M'īmārīya li'l-Usra al-Qaramānlīya fī Lībya», Master thesies, Faculty of Arts / Alexandria University, 2011.

$$
\text { -فكري، أحمد، "مسجد القيروان" ، القاهرة: دار العالم العربي، } 9 \text {. - rم. }
$$

-FIKRĪ, AHMĀ̄D, Masğid al-Qayrwān, Cairo: Dār al-Alam al-Arabī, 2009.

-كامل، عبد اله، "مساجد مدينة الدرج اللبيية الباقية من العصر العثماني الثاني"، دراسات فى آثار الوطن العربي، مج با،

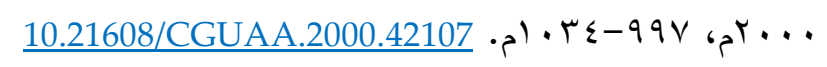

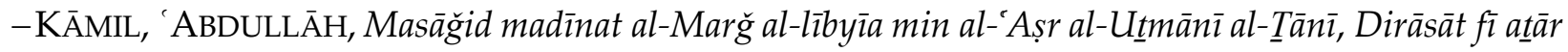
al-Watan al-'Arabī 3, 2000.

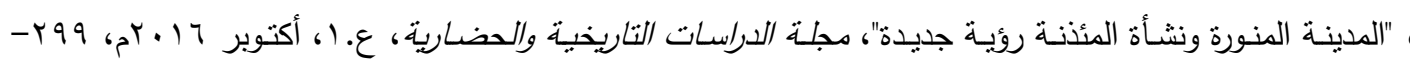

דrur

----------, «al-Madīna al-Mūnawra wa naš at al-mi'dana rū'ya ğadīda », Egyption journal of historial civil studies 1, 2016, 299-336

- الكحـلاوي، محمد، "العمارة الإسـامية فى الغرب الإسـلامي": عمائر الموحدين الدينية فى المغرب"، دكتوراة، كلية الآثار / جامعة القاهرة، 919 ام.

-KAḤLĀWĪ, MUḤAMMAD., «al- 'īmāra al-islāmīya fī al-g̉arb al-islāmī: 'Amāỉr al-muwahidīn aldinīya fī al-mağrib», PhD theseis, faculty of archaeology/ Cairo University, 1986.

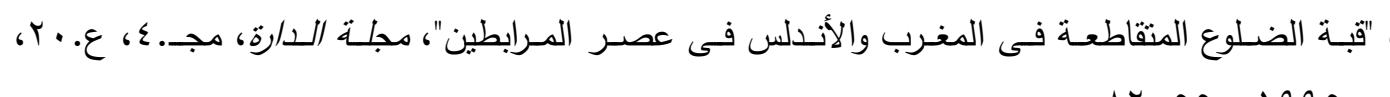

$$
\text { . Ar-00، } 1990
$$

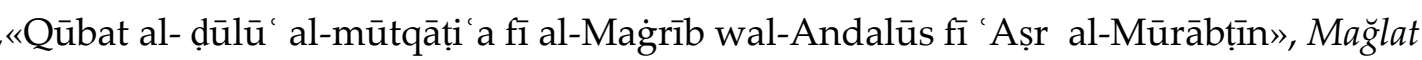
al-dara 4, №.20, 1995. 
-لعرج، عبد العزيز ، "مظاهر التأثير العثماني على الكنتجات الفنبة بالجزائر"، دراسات فحى آثار الوطن العربي، مج.0، ع.0،

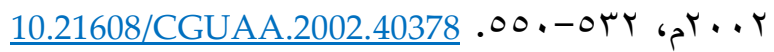

-LA RAĞ, 'ABD AL-AZīZ, «Mazāhīr al-ta'atīir al- 'Uțmānī 'alā al-Mūntağāt al-Fanīya bi'l-Ğazāir», Dirāsāt fì atāâr al-Wațan al-'Arabī 5, 2002.

-مالدونادو، باسيليو بافون، عمارة الدساجد فى الأندلس، ج. ؛، ترجمة: على منوفي، أبو ظبي: هيئة أبو ظبي للثقافة والتراث، $\cdot{ }^{2} \cdot 11$

-Maldonado, BASILIO PAVÓN, 'Imārat al-Msāăgid fī al-Andalus, translated by: 'Alī Munūfī, Abu Dhabi: Abu Dhabi Authority for Culture and Heritage, 2011.

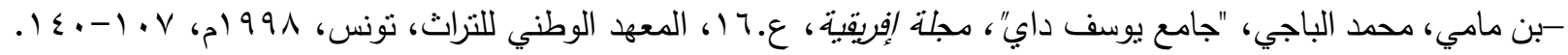

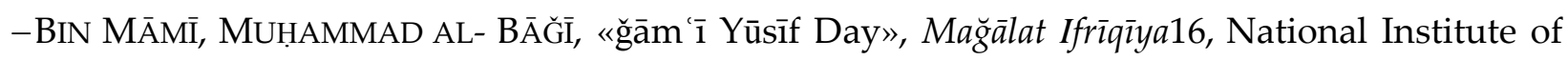
Heritage, Tunisia, 1998.

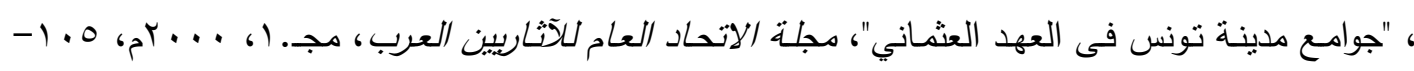

10.21608/JGUAA.2000.2389 • l1 V

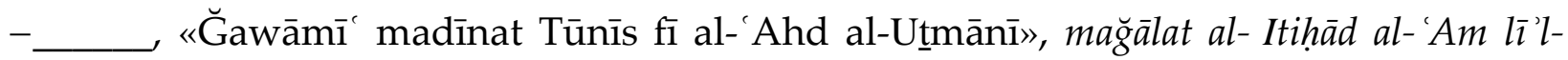
Atâ̄rìyīn al-'Arab1, 2000.

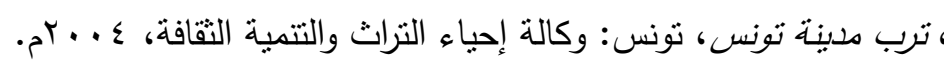

Tūrab madinnat Tūnīs, Tunisia: Agency for the Revival of Heritage and Cultural Development, 2004.

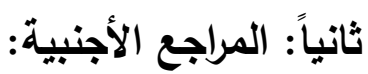

-AlATRASH, S.:«Mosque Architecture in the Islamic Civilization in Libya», JOURNAL OF NEAR ARCHITECTURE 1- 2, April 2018, 87-100.

-AZLITNI, B.: «The Libyan architectural features between tradition and modernization», International Journal for Housing Science 33, №.3, 2009, 137-148.

-Ben MAMI, M. B.: « La Mosquée M'Hammed Bey un exemple de la présence architecturale et artistique Ottomane dans la médina de Tunis», AFRICA12, serie, Tunis: Institut national du patrimoine, 1998, 1-22.

-BuhlfaiA, S. A.: «Historical background of Libyan mosque architecture », Master Thesis, Graduate School of Natural and Applied Sciences, Middle east technical University, 2006.

-CAILLÉ, J., La ville de Rabat jusqu'au protectorat français. Histoire et archeology, Casablanca: Publications de l'Institut des Hautes-Études marocaines, t. XLIV, 2006.

-CRESWELL, K.A.C., A Short account of Early Muslim Architecture, Cairo: The American University in Cairo Press, 1989.

-DHIF, S, L'architecture religieuse de Tripoli à l'époque Kāramānlī (1711-1835). Genèse d'une mosquée «hétéroclie», Al-Sabîl : Revue d'Histoire, d'Archéologie et d'Architecture Maghrébines, n5, 2018.

-DOKMAK, A.: «La utilización de las partes de la bóveda de arista en la arquitectura islámica y mudéjar en Al-Andalua, norte de África y Sicilia», Anales de Historia del Arte 19, 2009, 7-42.

-GoodwIN, G., A History of Ottoman Architecture, London: Thames \& Hudson Ltd, 1971.

-KALFAGIL, S., Türkiye'nin Üzerindeki Işik, Ankara: T.C. Kültur Bakanliği, 2002. 
-KUBAN, D \& O, Selçuklu Çağinda Anadolu Sanati, Istanbul, 2002.

-MArÇAIS, G., L' Architecture Musulmane d' Occident, Tunisie, Algerie, Maroc, Espage et Sicile, Arts et Métiers Graphiques, paris, 1954.

-O'Kane, B., Studies in Persian Art and Architecture, Cairo: The American University in Cairo Press, 1995.

-PROCHAZKA, A. B, KHAWĀRIZM OICC \& MARP, Architecture of The Islamic Culture, 1991.

-SÁNCHEZ, J., Jornades del Patrimonio de la Sierra de Huelva ,La Mezquita de Almonaster , 1993, 83-95.

-TORREs BALBÁs, L., La mezquita de Córdoba y las ruinas de Madinat Al-zahra, Editorial Plus-Ultra, Madrid, 1952.

Crónica Arqueológica de la España Musulmana , La mezquita mayor de Qayrawān II, 1981, 53-57.

, Cronica Arqueologica de la Espana Musulmana ,La mezquita mayor de Almería, 5, 1981, 249-276. 
الصور

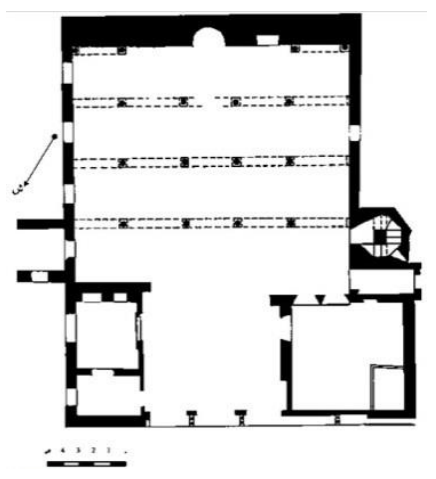

(شكل r ) مخطط جامع القصبة الخارجي

بالجزائر • بن بلة، المنشآت الدينية

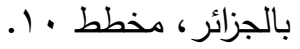

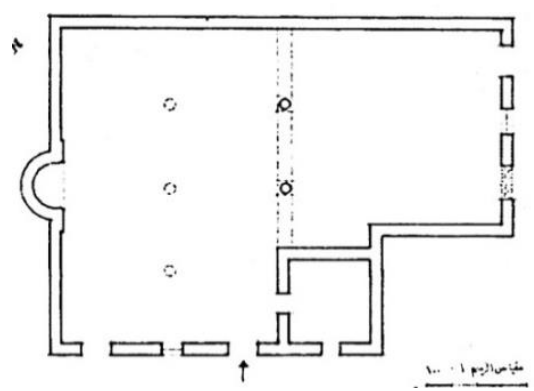

(شكل ع ) مخطط جامع حمد الثنتيوي

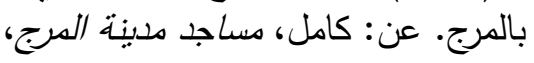

.1 . I 1 ،

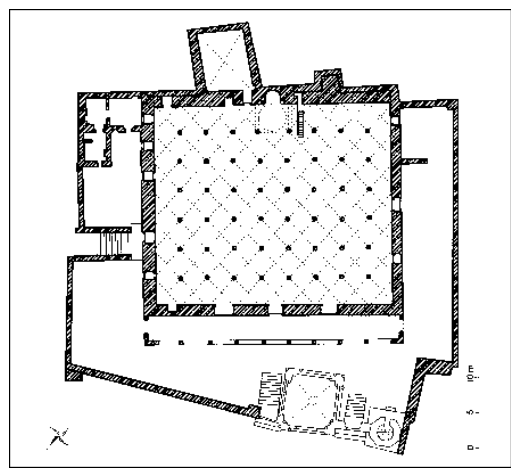

(شكل T) مخطط جامع يوسف داي

بتونس. عن: بن مامي، جامع يوسف يوسف دائ

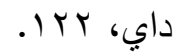

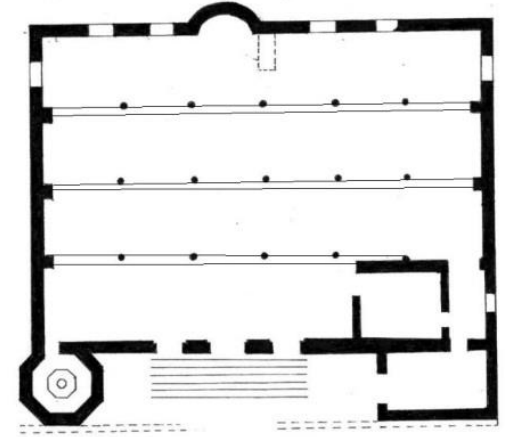

(شكل (1) مخطط الجامع الحنفي بالبليدة.

بتصرف، بن شامة، المنشآت المعمارية

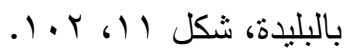

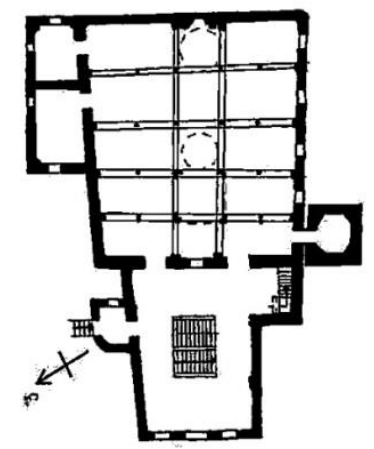

(شكلr) مخطط جامع لخضر

بقسنطينة. عن: دحدوح، أنماط التخطيط

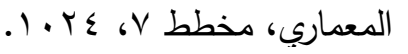

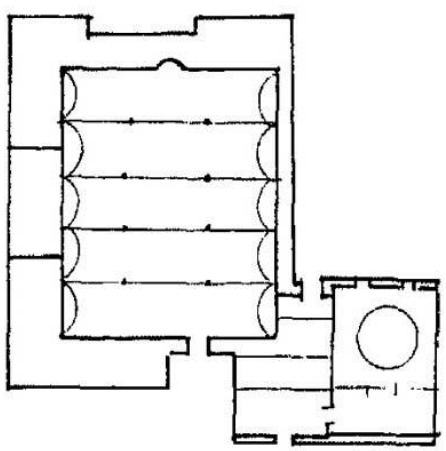

(شكله ) مخطط جامع الثيخ فتح الله بمصراتة. عن: البلوشي، تاريخ معمار الفيخ

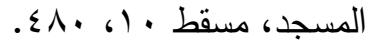




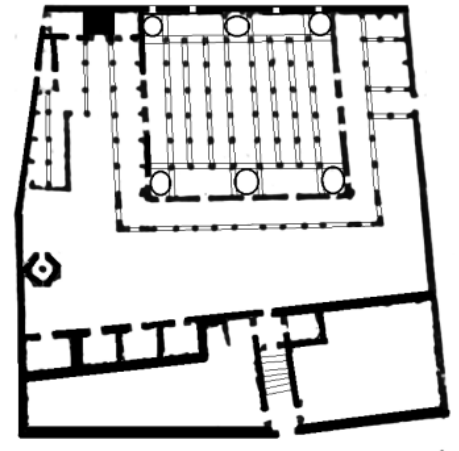

(شكل^) مخطط صاحب الطابع بتونس. عن: MARÇAIS, Le Architecture Musulmane de Occident, 267,464.

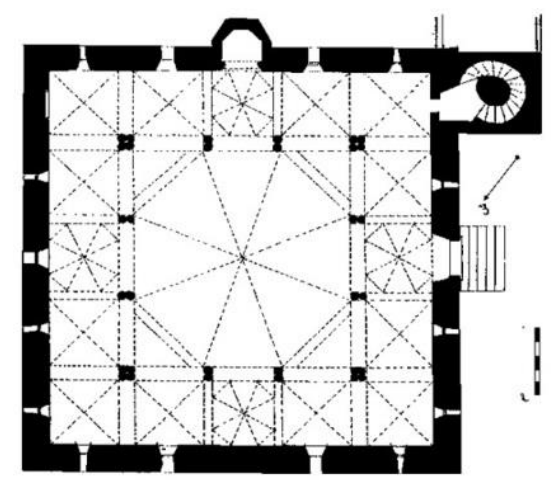

(شكل • ( ) مخطط جامع عين البيضاء بمعسكر . عن:

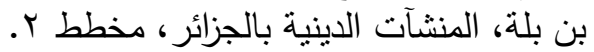

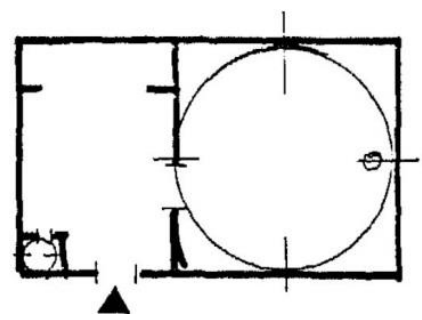

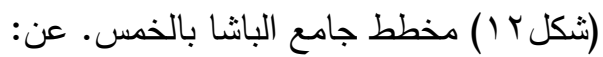

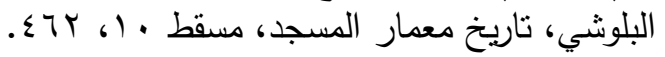

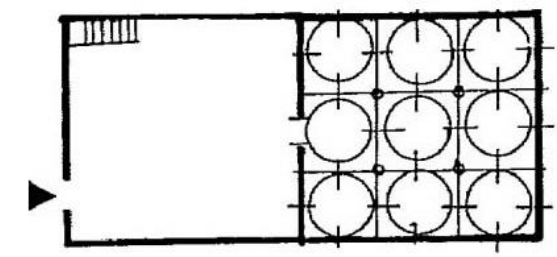

(شكل \& ( ) مخطط جامع الزغاغنة بأوجلة. عن:

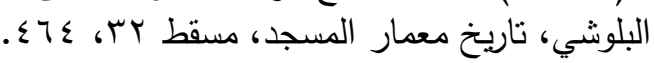

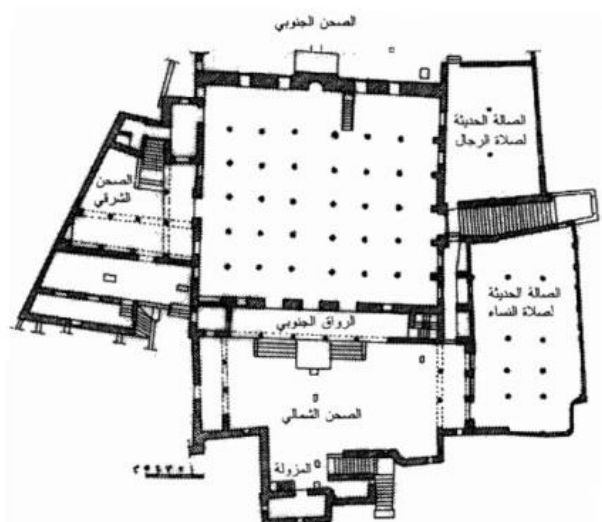

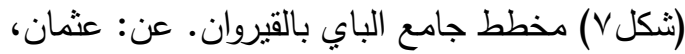

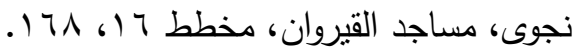

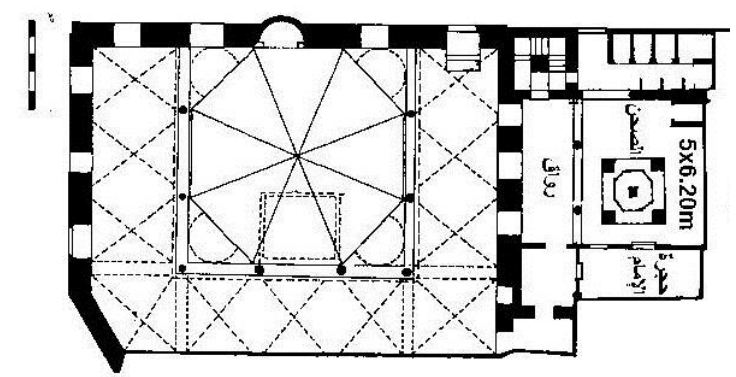

(شكل9 ) مخطط جامع صفر بالجزائر • عن : حاج

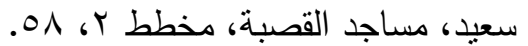

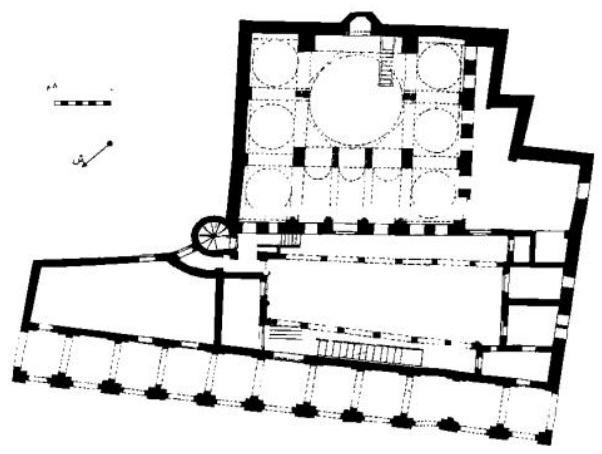

ش (كل (1) (1) مخطط جامع الباي بعنابة. عن: دحدوح،

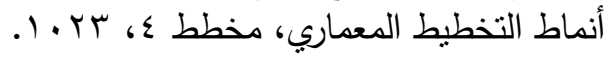

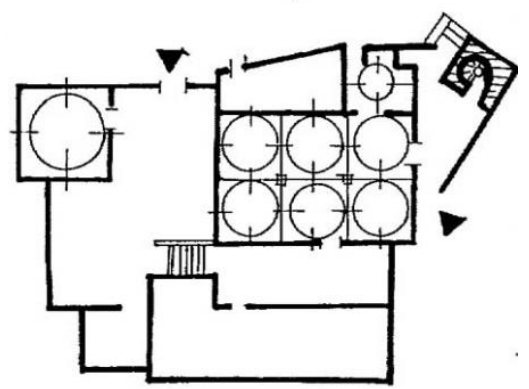

(شكل r ( ) مخطط جامع سيدي سالم المشاط بطرابلس.

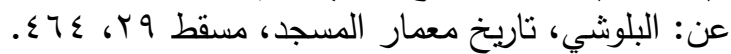




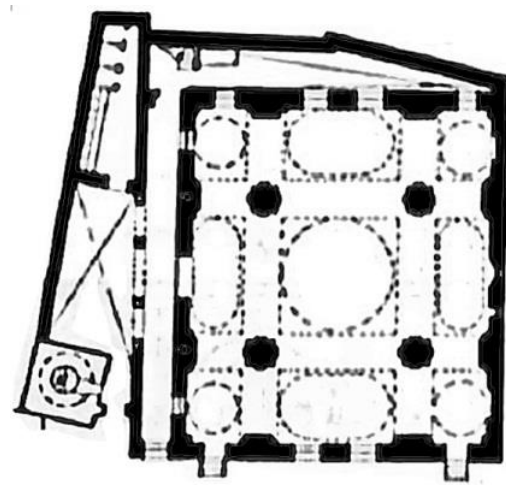

(ثكل 7 () ) مخطط الجامع العتيق بيني غازي. عن:

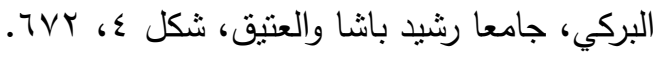

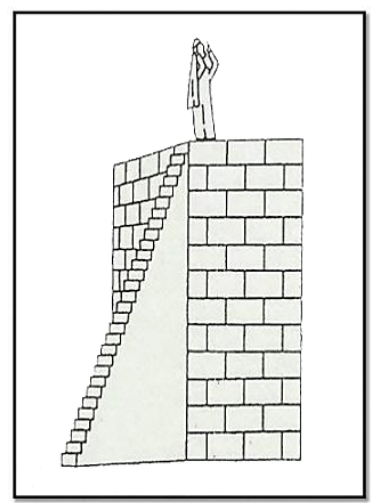

(شكل1/ () تصور لـ"المطمار"، عن :كامل،

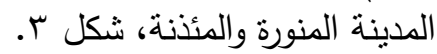

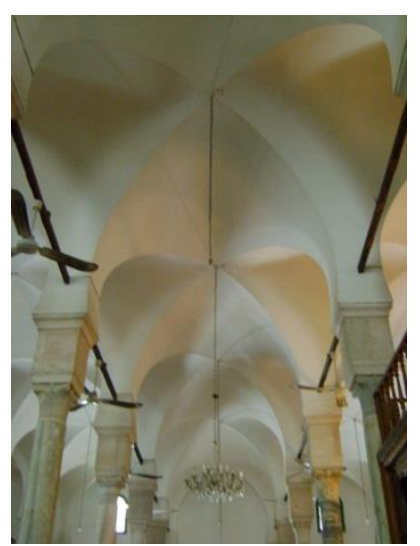

(لوحة ا ) نموذج للأقبية المتقاطعة ببيوت

الصلاة. (1) نصودير الباحثة

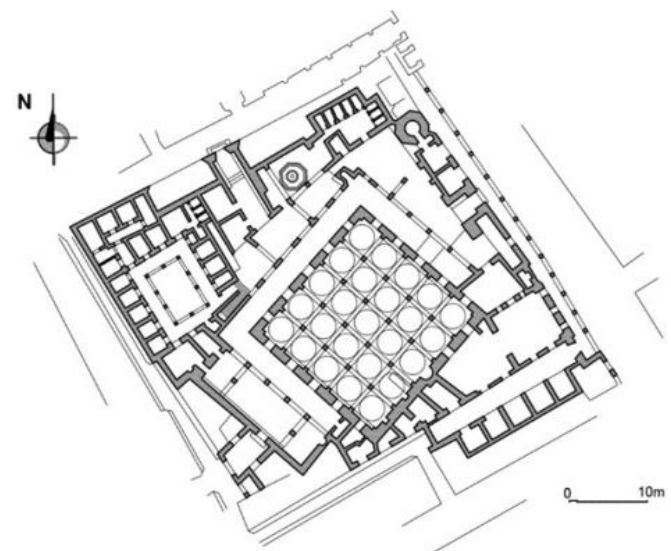

(شكل 10 ) مخطط جامع أحمد باشا القرمانلي بطرابلس.

عن: DHIF, L'architecture religieuse de Tripoli, fig.4

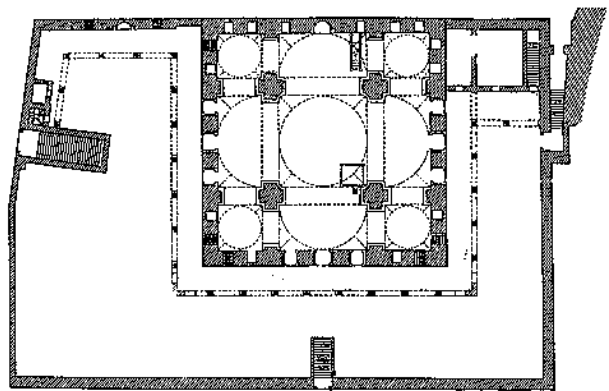

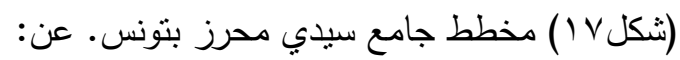

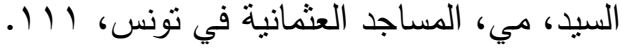

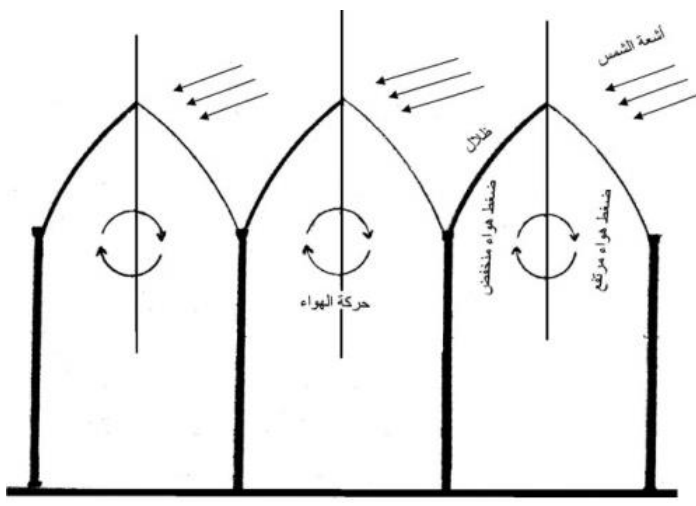

(شكل 9 ( ) نوضيح لنوع التسقيف وعلاقته بحركة الهواء.

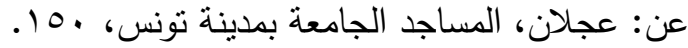




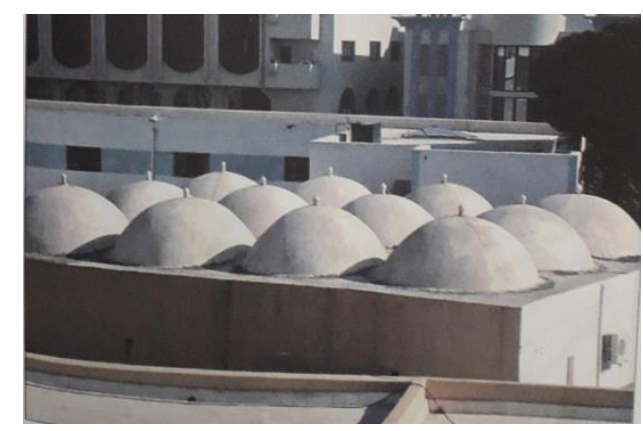

(لوحةr) القباب المتعددة بجامع خليل بانشا. عن:

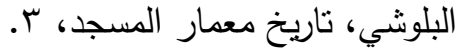

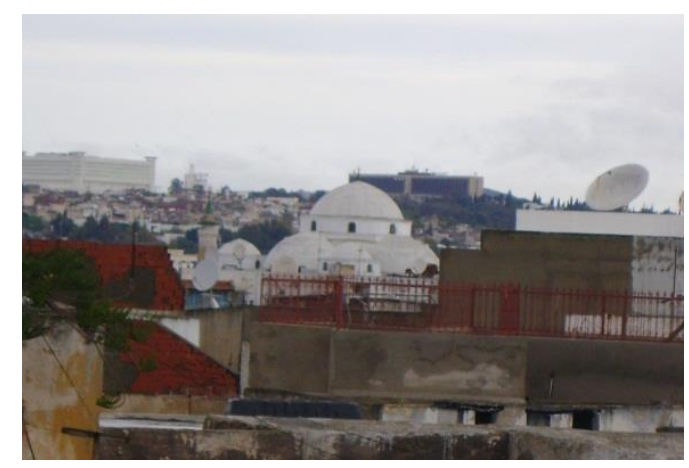

(لوحةه) القبة المركزية وأنصاف القباب، جامع سيدي محرز بنونس، تصوير الباحث.

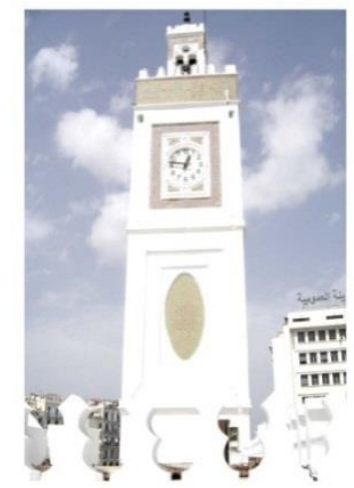

(لوحة V) المئذنة المربعة بالجامع الجديد بالجزائر • عن: بن بلة، المنشآت الدينية، صورة باليع الجالد بالئر .

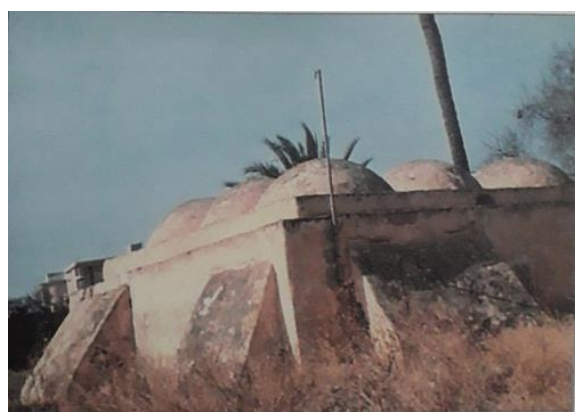

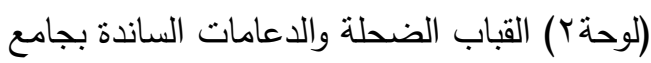

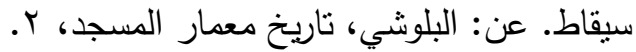

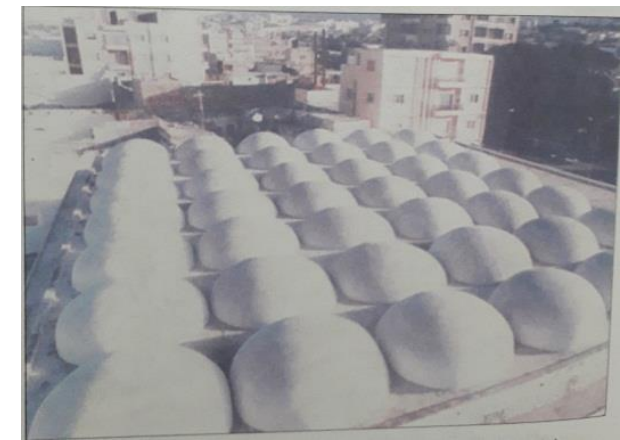

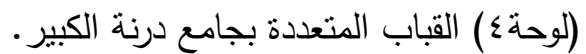

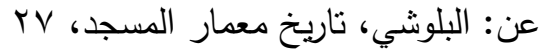

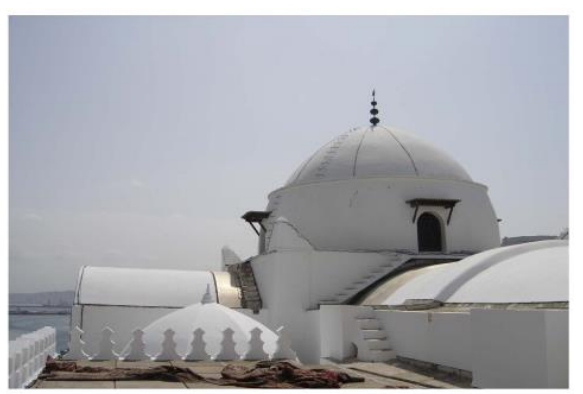

(لوحةج) القبة المركزية بالجامع الجديد بالجزائر .

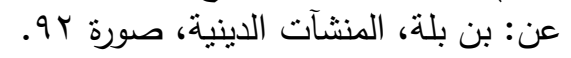




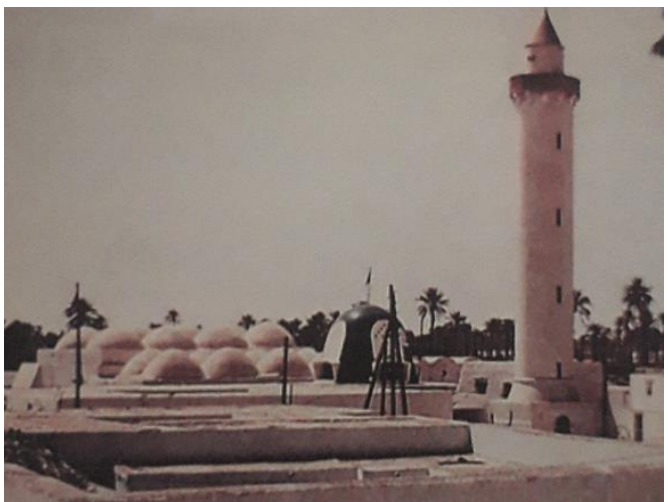

(لوحة 9) جامع سيدي ع السلام الأسمر .

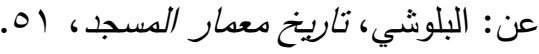

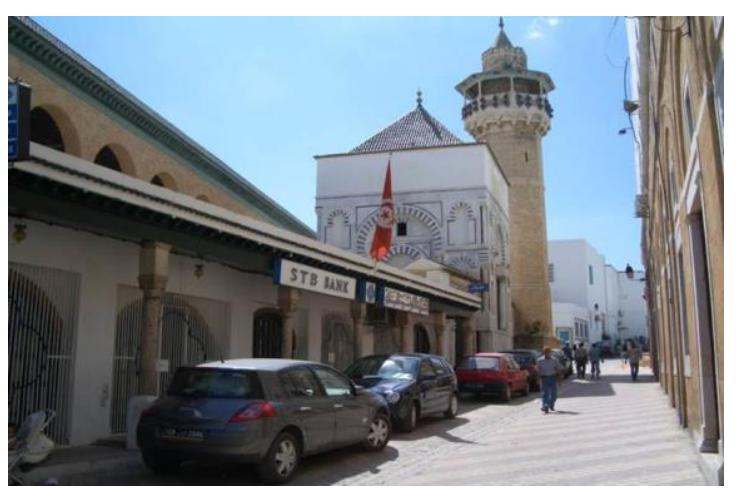

(لوحة | (1) المئننة والضريح بجامع

يوسف داي بتونس. تصوير الباحث.

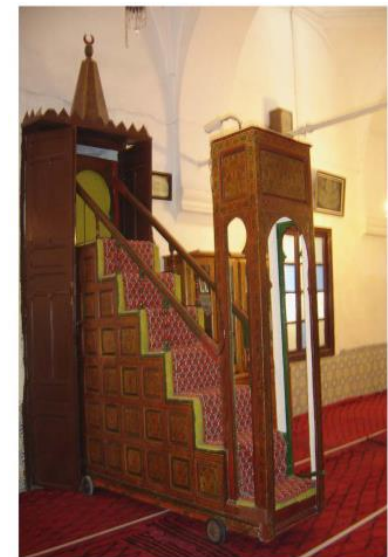

(لوحة ـ ا ) المنبر الخشبي بجامع

الباشا بوهران. عن: بن بلة النة،

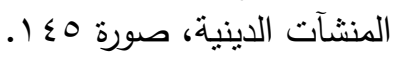

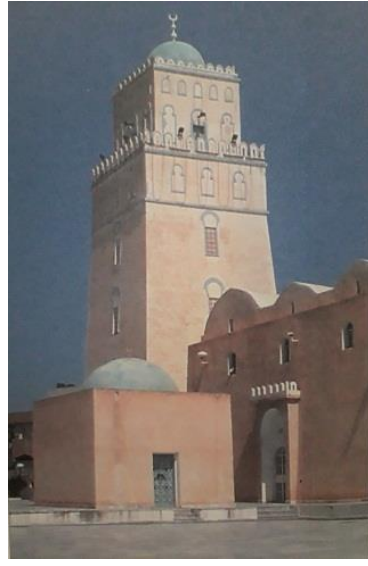

(لوحةم) مئذنة جامع مراد أغا بتاجوراء.

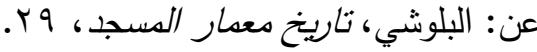

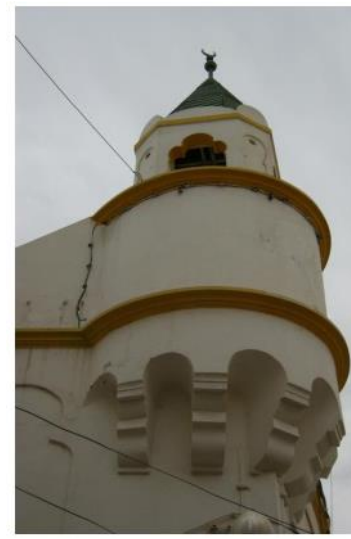

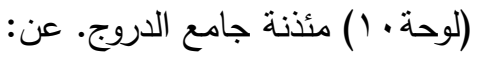

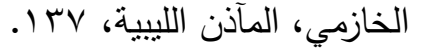

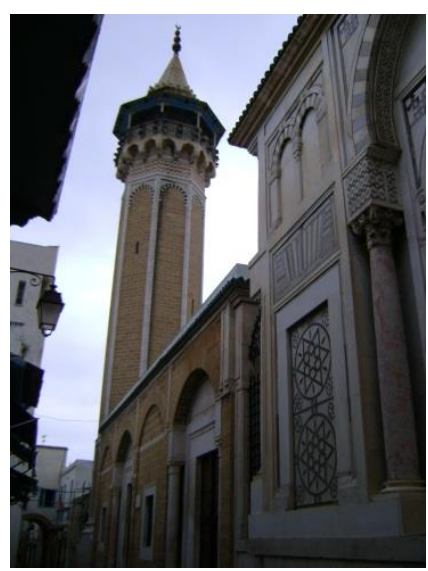

لوحة( ا ()): المئذنة المثنة

بجامع حمودة باشا بتونس. تصوير الباحث. 


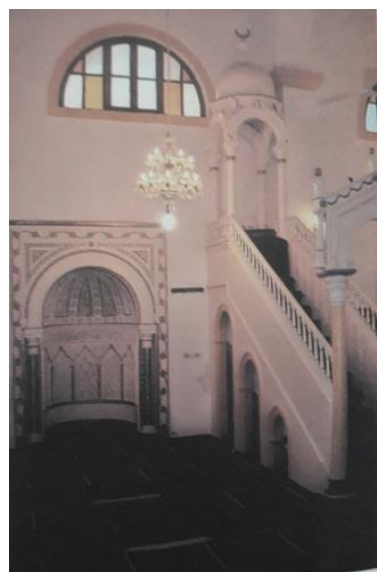

(لوحة 1 (10) منبر ومحراب جامع الخروبة.

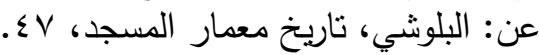

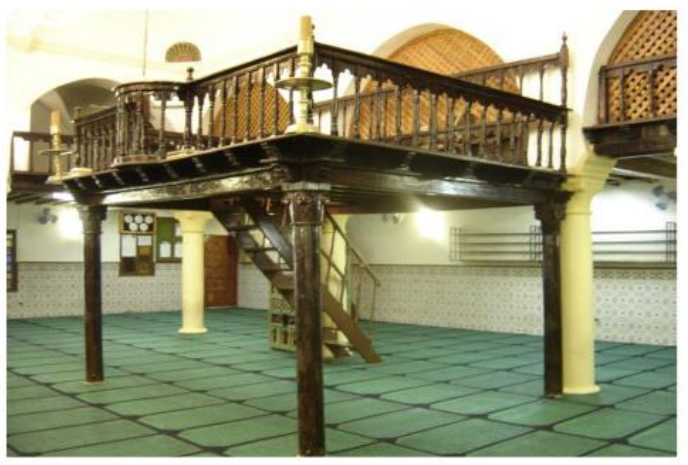

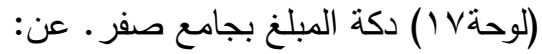

بن بلة، المنشآت الدينية، صورة باهع

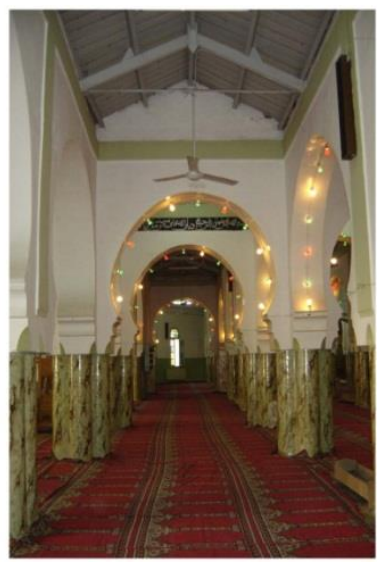

(لوحة 9 () بيت الصلاة بالجامع الكبير بمعسكر.

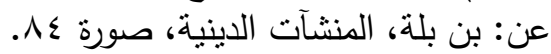

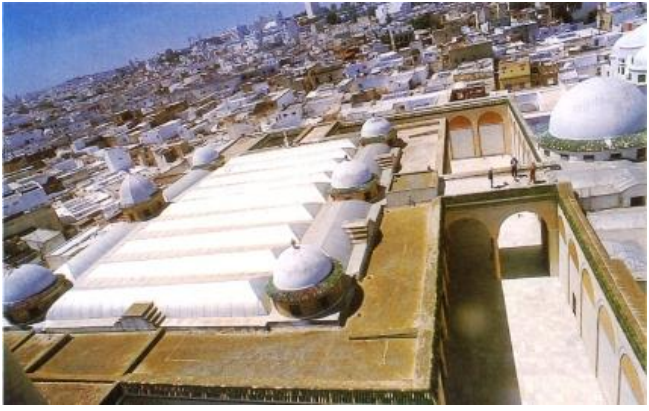

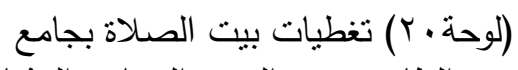$$
\text { صاحب الطابع. عن: السيد، المساجد العثمانية }
$$

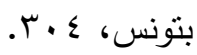

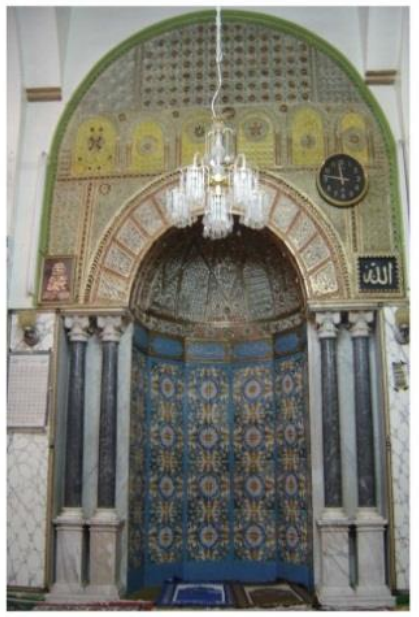

(لوحة7 1 ) محراب جامع الكتاني. عن: بن بلة،

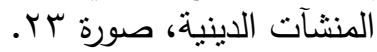

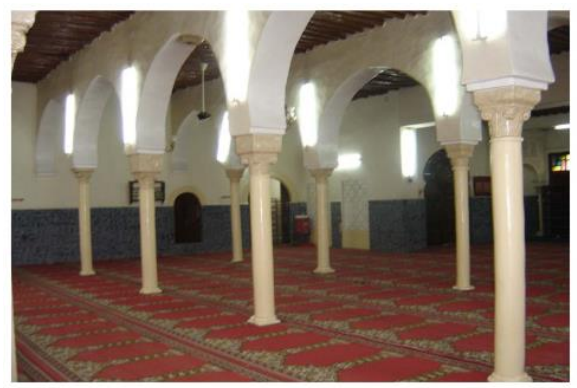

(لوحةم/ (ليت الصلاة بجامع القصبة البراني.

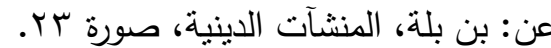

